\title{
Políticas Sociales y Quídam : Procesos y Representaciones de los Sujetos Emergentes en las Estructuras Estatales surgidas en la Década de los Noventa en Chile
}

Tesis presentada para obtener el grado de Magíster en Antropología y Desarrollo, Universidad de Chile (1)

\section{Andrea Avaria Saavedra (andreaavaria@hotmail.com)}

Palabras Claves: Representaciones/ Políticas Sociales/ Inclusión-exclusión/ Sujetos emergentes/ Mujeres y Personas con discapacidad

\section{Resumen}

La presente investigación es una invitación a situarse en la década de 1990 para observar las observaciones que realizan los hacedores de políticas sociales respecto a los sujetos emergentes "mujeres" y "personas con discapacidad".

En primer lugar, en la década de 1990 se da inicio a lo que se ha llamando la transición a la democracia, proceso que se ha situado sobre la base de la reforma y consolidación del modelo económico iniciado por el gobierno militar y que ha regulado las relaciones Estado Nación.

Aparentemente los movimientos sociales vinieron a instalar problemáticas sociales invisibles, desde donde el Estado habría visibilizado e incorporado a sujetos emergentes. En otras palabras, los sujetos emergentes (mujeres, indígenas, jóvenes, personas con discapacidad, adultos mayores) se han traducido en la producción de nuevas políticas sociales y en la construcción o redefinición de nuevos espacios sociales.

A partir de una mirada que permita dar cuenta de los procesos de elaboración y definición de los sujetos a los cuales se dirigen las políticas sociales, podré dar cuenta de las representaciones (definiciones culturales, conceptos, figuras de los sujetos emergentes), así como a los mecanismos que operan, representacionalmente, a través de los cuales los sujetos quedan fuera/dentro (inclusión/exclusión), del sistema social.

Para el logro de lo anterior se recopilaron antecedentes, bibliográficos, documentación, conversaciones, discursos y publicaciones, sobre las que se elaboró un análisis, para dar cuenta de las observaciones de los hacedores de políticas sociales, en parte de la estructura de MIDEPLAN, centrados principalmente en el SERNAM (Servicio Nacional de la Mujer) y FONADIS (Fondo Nacional para la discapacidad), desde una perspectiva constructivista de la investigación sociocultural.

\section{DESCRIPCIÓN DEL PROBLEMA}

A continuación vengo a presentar el estudio "Políticas Sociales y Quídam (2): Procesos y Representaciones de los Sujetos Emergentes en las Estructuras Estatales surgidas en la Década de los Noventa en Chile". Con el fin de dar cuenta de las definiciones y contextos necesarios que permitan entender los objetivos generales y específicos de la presente investigación, entregaré en esta sección los elementos principales que están contenidos en ella.

La década de los noventa en Chile indican el inicio de lo que se ha llamado transición a la democracia. La transición ha estado marcada por diferentes procesos, tanto políticos como 
sociales, a través de los cuales se han ido consolidando el desarrollo de la reforma iniciada durante el gobierno militar y -al mismo tiempo- el afianzamiento de un modelo económico que ha regulado las relaciones y definiciones de Estado-Nación.

Los participantes de los diferentes movimientos sociales y organizaciones que se incorporaron activamente en los procesos de recuperación democrática (que venían de los años ochenta), no sólo se hicieron cargo de la resolución de problemáticas sociales que el aparato estatal no consideraba, sino también permitieron visibilizar a otros actores sociales, así como las realidades de éstos. Estos sujetos emergentes son mujeres, indígenas, jóvenes, adultos mayores y personas con discapacidad.

Cuando nos referimos a sujetos emergentes (actores sociales, beneficiarios, excluidos, minorías, etc.), nos remitimos a "nombres" o "categorías" con las cuales se intenta aprehender a un tipo de individuo, a alguien que -al igual que otros-compartiría características determinadas o condiciones que los hacen definibles como conjunto. En este sentido, se debe entender por sujetos emergentes todos aquellas/ os sujetos a los cuales se dirigen las políticas sociales generadas por las nuevas estructuras estatales de la década de los noventa en Chile.

Estos sujetos emergentes, como parte del movimiento social anterior a la elección del primer Gobierno de la Concertación, generaron demandas que se orientaron a la democratización de las relaciones en contextos de diversidad cultural y social. Los aportes de estos actores no sólo hay que mirarlos desde la perspectiva de la recuperación de espacios sociales y políticos. Desde el punto de vista de las ciencias sociales, resulta interesante analizar que este fenómeno social generó estructuras estatales, las que crearon conocimiento en torno a las temáticas que les afectaban y los contextos en los que éstos se hacían evidentes. Este material ha resultado ser un insumo importante para la orientación de proyectos y políticas específicas de los gobiernos concertacionistas.

Es decir, al mismo tiempo que estos sujetos emergentes presionan al Estado para el cumplimiento de los acuerdos nacionales e internacionales que el país ha suscrito en diferentes momentos, el Estado ha requerido instituciones que operacionalicen estas demandas para lograr un mejoramiento de las condiciones sociales, así como también en la calidad de vida de estos sectores.

En otras palabras, la emergencia de nuevos sujetos sociales se ha traducido en la producción de nuevas políticas sociales y en la construcción o redefinición de nuevos espacios estatales, es decir, se originaron procesos que permitieron instalar estructural y legalmente mecanismos que pudieran asegurar que estos sujetos y sus problemáticas ocuparan un espacio en la estructura estatal.

Estas son acciones estatales cuyo objetivo es hacerse cargo de las necesidades y problemáticas de un grupo social determinado, es decir, de los sujetos emergentes. Las políticas sociales se enmarcarán en orientaciones generales definidas por cada gobierno, las que le otorgarán un perfil específico que -finalmente- redundará en modos de establecer relaciones entre el Estado y la nación, así como también en la focalización de los recursos y de las orientaciones de éstas.

Estas nuevas estructuras estatales deben entenderse como aquellos espacios construidos o elaborados por el Estado para atender as problemáticas y necesidades que afectan a un determinado grupo de sujetos. Estas estructuras asumen diferentes características, de acuerdo a las cuales tendrán diversos alcances, que influirán o no en la resolución de problemáticas que 
afectan a los actores sociales a los cuales se dirigen. Para el caso del Estado chileno, estas estructuras son: SERNAM, FONADIS, CONADI, FOSIS E INJUV. Estas estructuras están adscritas a un sistema mayor conocido como MIDEPLAN (3). Estas estructuras elaboran políticas sociales que son objetivo del presente estudio.

Las políticas sociales son diseñadas y articuladas por un equipo, con el fin de mejorar condiciones sociales y calidad de vida de grupos que se encuentran bajo condiciones o niveles de pobreza o menoscabo social. Estos equipos, en su calidad de trabajadores del sector público y por encargo del gobierno, diseñan orientaciones y estrategias de focalización de recursos destinados al mejoramiento de la calidad de vida de éstos. Es posible afirmar, entonces, que las políticas contienen en su descripción y definición representaciones de sujetos hacia los cuales conducen su acción o hacia aquellos a los que atenderá.

Es en estas definiciones de los sujetos a los cuales se dirigen las políticas sociales, a través de las políticas en sí, donde podré dar cuenta de los procesos de representación social. Las representaciones sociales deben ser entendidas como aquellas definiciones culturales, conceptos o figuras de los sujetos emergentes que elaboran las estructuras estatales para diseñar y aplicar las políticas sociales.

Finalmente, cuando me refiero a sujetos emergentes y a políticas sociales, también me estoy refiriendo a mecanismos de inclusión/ exclusión. Estos serán los que permitan dar cuenta o describir los procesos a través de los cuales los sujetos quedan fuera o dentro del sistema social. En este sentido, también será posible observar si las políticas en su definición u operativización estarán favoreciendo construcciones de inclusión/ exclusión de los sujetos a los cuales afirman querer incluir de acuerdo al orden social que se define para ello.

Cabe indicar que los aspectos que he señalado constituyen un primer acercamiento de los elementos que serán abordados en este estudio. A partir de los antecedentes y contenidos, se profundizará y dará cuenta del modo en que éstos serán traducidos, para objeto del posterior análisis de los datos.

Dado el desarrollo anterior, es pertinente explicitar los antecedentes que permiten el marco de este estudio.

\section{COMO SE HA ESTUDIADO EL TEMA EN CHILE}

Para la recopilación de antecedentes en relación al tema, me he remitido a bibliografía que recoja miradas sobre políticas sociales y los modos en que éstas han sido construidas, es decir, antecedentes que permiten reconocer un análisis en cuanto la generación, operacionalización de políticas sociales y la orientación de éstas a actores sociales diversos.

Desde los antecedentes recogidos ha sido posible distinguir diferentes modos de acercamiento respecto a la temática, la concepción, operacionalización y consolidación de los procesos de políticas sociales.

En el artículo de K. Araujo y otras (4) así como el artículo de J. Bengoa (5), ambos plantean que el establecimiento de temáticas ligadas a actores sociales determinados, como por ejemplo mujeres y mapuche, se originarían en la participación de éstos en los movimientos sociales durante el gobierno militar. En el caso de lo mapuche el autor se refiere principalmente a los procesos de conformación de políticas y acciones ligadas a lo indígena, no sólo en el país sino en el contexto latinoamericano. Las demandas de estos actores sociales, habrían 
permanecido, por cierto, invisibilizadas o subordinadas a los requerimientos generales, de recuperación democrática y mejoramiento de las condiciones de pobreza y marginalidad en que éstos se encontraban. Ambos autores afirman que es a partir de los acuerdos previos al primer gobierno democrático de la década de los noventa, que se consolida la conformación de estructuras estatales. El Estado a través del establecimiento de estructuras o mecanismos que se responsabilizan de las problemáticas, demandas, serían resueltas de acuerdo a las características de los actores, esto supone la focalización como estrategia para dirigir los proyectos, recursos, políticas, etc.

En los artículos se afirma que son los propios actores, los que por medio de diferentes mecanismos de influencia social, presionan para la implementación de acciones o estructuras que tiendan a la resolución de la problemática que les afectan. Serán los y las propias afectadas las que den origen a estas nuevas estructuras. También destacan que estos movimientos se consolidaron y reforzaron muchas veces por el conocimiento y el antecedente de acuerdos internacionales y de movimientos que se articulaban globalmente y que permitían la visibilización del o los problemas más allá de las fronteras nacionales.

Otra posición en algunos aspectos similar se deja ver en la tesis de R. Godoy (6), quien señala que la reformulación de la concepción y rol del Estado Nación, ha impactado de manera significativa los procesos que al interior del país se han desarrollado, produciéndose una resignificación del Estado y al mismo tiempo un cambio en los modos de ver y articular formas de organización y articulación de la sociedad civil. Las evaluaciones de nuevos procesos favorece la aparición de ciertos sujetos, se promueve la participación de estos en espacios más públicos. Para la promoción de la participación de los actores sociales se ha requerido establecer un nuevo orden social. La participación significará también, pensar y modificar las relaciones que se dan entre sujetos y Estado.

Por otra parte el artículo de MIDEPLAN (7) destaca más bien los procesos o aspectos relativos al tema de la focalización de las políticas sociales. Las políticas sociales surgirían a partir de voluntades políticas o de la presión de grupos sociales. Lo que llama la atención es la definición de vulnerabilidad que se le otorga a determinados grupos o personas, la que afirma que los sujetos (vulnerables), no se encontrarían en condiciones que les permitieran instalarse socialmente o hacerse cargo de su problemática.

En síntesis, a partir de la revisión bibliográfica, los antecedentes a través de ella obtenida, es posible afirmar que los analistas de políticas sociales, visualizan éstas fundamentalmente desde los sujetos que aparecen en ella (los objetos de focalización), se detienen por tanto en dar cuenta de que tipos de sujetos se trata, cuales son las características de los sujetos hacia los cuales se orientan recursos y políticas sociales. Estas definiciones surgen desde sus propias significaciones y dejan fuera las significaciones de los sujetos que intervienen en la definición de las políticas. Se refieren a las condiciones del contexto que darían origen o permitirían la aparición de determinados sujetos. En este sentido los autores refieren a sus propias distinciones, a las que producen mientras observan determinados sujetos en relación a una estructura determinada.

En este sentido, es que no creo necesario identificar las distinciones, de los sujetos a los cuales se dirigen los esfuerzos estatales, ni tampoco los contextos en los cuales estos aparecen, sino más bien reconociendo que "aparecen o surgen" determinados sujetos, en contextos sociales y políticos determinados, es relevante dar cuenta de los procesos que desde el aparato estatal producen representaciones, representaciones que dan cuenta de "tipos de sujeto emergentes" hacia los cuales se orientan las políticas sociales. Estos sujetos emergentes podrán constituirse 
como tipificaciones (representaciones) las que determinan las distinciones que se asocian a los procesos de inclusión o exclusión de estos sujetos al sistema social desde la estructura estatal.

\section{COMO SE ESTUDIA EL TEMA EN ESTA INVESTIGACIÓN}

\section{Objetivos}

\section{OBJETIVO GENERAL}

Dar cuenta de los sujetos que han construido las estructuras estatales surgidas en la década de los noventa en Chile a través de sus políticas sociales.

\section{OBJETIVOS ESPECIFICOS.}

1. Describir las representaciones a través de las cuales la estructura estatal caracteriza a los sujetos de sus políticas: mujeres y personas con discapacidad. (qué sujetos)

2. Describir los elementos que resignifican a los sujetos mujeres y personas con discapacidad en la estructura estatal de manera de permitir la incorporación de éstos en la estructura y política social (como)

3. Describir los elementos de inclusión/exclusión de los sujetos mujeres y personas con discapacidad que utilizan la estructura estatal y las políticas sociales.(por qué)

\section{Marco Metodológico}

Para desarrollar esta investigación, procedo a especificar los pasos metodológicos que permiten cumplir con los objetivos específicos. La justificación de esta metodología está en concordancia con el marco teórico desarrollado, puesto que este estudio se enmarca en una metodología cualitativa de carácter exploratorio, que ocupa la perspectiva metodológica de observación de segundo orden. Esto último se justifica porque no observo los sujetos emergentes (que sí lo hacen las estructuras estatales), sino que mi objetivo es la observación de la observación de esas estructuras del Estado (segundo orden). Por eso interesan tanto sus comunicaciones escritas como verbales, por cuanto ellas reflejan los contenidos y procesos representacionales de sus políticas sociales.

\subsection{Selección de la Unidad de Estudio (dónde estudiar)}

\subsubsection{Selección de Estructuras Estatales}

Para recoger información que de cuenta de los procesos y mecanismos involucrados en la construcción de representaciones, ha sido necesario realizar una revisión de al menos dos de las estructuras estatales dependientes del MIDEPLAN. Estas estructuras como es el caso del Servicio Nacional de la Mujer (SERNAM), el Fondo Nacional para la Discapacidad (FONADIS), generadas en los inicios de los noventa y que responden a las características de ser creadas para atender a sujetos sociales, a sujetos emergentes, proponen orientar sus acciones al mejoramiento de las condiciones sociales y culturales de las mujeres y de las personas con discapacidad respectivamente. Ambas estructuras son las que han permanecido a través de los 
proceso de constitución delos gobiernos de la Concertación, se caracterizan por ser estables y permanentes, además de presentar características y líneas programáticas similares a nivel nacional.

\subsubsection{Selección de Equipos de Trabajo}

Considerando la limitación presupuestaria para la realización de un estudio de características más profundas, me dispuse a realizar una focalización que permitiera recoger elementos orientadores de conclusiones, que por cierto se constituyen en una aproximación y no podrán considerarse como una generalización de los resultados. El acercamiento a los servicios e instituciones se realizó a través de la focalización sobre uno de los departamentos o de alguna sección de la estructura institucional (8). Departamentos o secciones dedicadas, como parte de sus funciones a la generación/ operacionalización de políticas en el contexto de la población a la que atienden y de aquellos orientados a la investigación o a la generación de insumos para la elaboración de estrategias o políticas sociales desde el marco institucional.

Con los equipos con que se dio rapport se realizó el trabajo de entrevista, se llevaron a cabo al menos dos entrevistas por equipo perteneciente a cada servicio o establecimiento Sernam, FONADIS, seleccionado. A las entrevistas realizadas a los equipos de Sernam y FONADIS, se sumaron entrevistas realizadas a las contrapartes institucionales de MIDEPLAN, estas entrevistas, en total diez, dicen relación con la posibilidad de articular la relación temática y técnica desde la estructura que sostiene y acoge las institucionalidades (Sernam y FONADIS)

Se aplicó una entrevista semi-estructurada para lo cual se requirió que los equipos contaran con las siguientes características, como criterios de selectividad:

Deseo de participación. Aceptación y motivación para participar en la entrevista.

Equipos encargados de generar, operacionalizar en lo técnico políticas sociales (No son equipos encargados de la operación en terreno, sino equipos que orientan el que hacer).

La antigüedad de los equipos no resultó importante, dado que los procesos y representaciones operan tanto en los nuevos equipos como en los más antiguos.

Que los equipos o secciones cuenten con material escrito, tales como documentos de trabajo, investigaciones, manuales, publicaciones periódicas, etc.

2.2 Focalización de los Elementos a Estudiar (qué estudiar)

Para la recopilación de información y la generación de antecedentes que permitieran la realización del estudio, se procedió a recoger, registrar y posteriormente analizar, las conversaciones generadas en el marco de las entrevistas a los equipos seleccionados.

Análisis de textos, documentos, escritos que los equipos entrevistados hayan generado para la elaboración, difusión, operacionalización de políticas sociales originadas en las estructuras estatales estudiadas.

\subsubsection{Conversaciones}

Las conversaciones generadas a partir de la aplicación de una entrevista, permitieron recoger las distinciones que los hacedores de políticas sociales realizan, acerca de los nuevos sujetos. Las conversaciones contienen las representaciones de los sujetos emergentes a los cuales se dirigen las políticas sociales o acciones, estas se constituyen en un registro vívido de los modos en que los equipos estructuran las representaciones (tipificaciones) y procesos a través de los cuales se generan mecanismos de inclusión o exclusión. 


\subsubsection{Textos}

Se procedió a estudiar los textos (documentos oficiales, orientaciones, publicaciones, bases de concursos, folletos, póster o afiches) que los equipos elaboran para difundir, orientar, etc, a los equipos o programas dependientes de la estructura desde la cual se generan. Para la revisión de los textos, se seleccionó aquellos textos que reflejen los problemas del estudio, extrayendo párrafos, imágenes y textos.

El análisis de los textos fue enfocado principalmente a dar cuenta de las representaciones, imágenes de sujetos, a la producción conceptual que hacen referencia a estos y los procesos a través de los cuales se generan mecanismos de inclusión o exclusión.

2.3 Instrumentos de Investigación (con qué)

Para la recopilación de los antecedentes a través de las conversaciones y la revisión de textos, se diseñó una entrevista semiestructurada y una pauta de análisis de los textos, respectivamente, de modo de obtener insumos que permitieran dar cuenta de las representaciones de los sujetos y de los procesos de inclusión y exclusión implícitos en éstos.

\subsubsection{Pauta de Análisis de textos}

La pauta de análisis de los textos se elaboró a partir de los elementos que pudieron ser recogidos durante una primera aproximación a la institución, a los equipos, así como también a los documentos y textos escritos. Esta entregó insumos para el análisis de contenido específico asociados a los textos de los imágenes.

\subsubsection{Entrevistas}

La elaboración de la entrevista semiestructurada se realizó desde un acercamiento primario a la institución y a los equipos, principalmente de aquellos elementos que fue posible extraer a partir del análisis de los textos; de manera de recoger a través de ella elementos generales y específicos de las instituciones, lo que permitió ir adecuando ésta para una mejor consecución de los objetivos.

\section{Marco Teórico}

Este estudio contiene una aproximación a la temática desde una perspectiva constructivista de la investigación sociocultural. Es decir, utilicé un acercamiento desde formas blandas del constructivismo social. La razón de ello es que parece relevante abrir la descripción de los sujetos que dan cuenta, que aparecen desde las políticas sociales, es decir, la posibilidad de resaltar los procesos de construcción y los tipos de sujeto que construyen las políticas sociales. Los acercamientos que se relacionan con las tipificaciones de los sujetos que describen las políticas sociales y los actores o sujetos sociales que éstas comprenden, por ello la relevancia de abrir, desde el mundo de los hacedores de políticas sociales, explorar los procesos que están contenidos en éstas, que constituyen a los sujetos emergentes; mecanismos de inclusión/ exclusión contenidos en estos.

Para realizar el estudio desde una perspectiva constructivista, se consideraron los siguientes conceptos y autores, por cuanto ellos han operacionalizado esta teoría y el estudio de la realidad social. La definición de los conceptos claves de análisis permitieron establecer un sistema conceptual base.

En el contexto de modernización del Estado chileno, las políticas sociales se han constituido en ejes de sostenimiento e instalación de procesos de reforma que, por un lado apuntan a la 
consolidación de una propuesta de relación Estado - Nación y por otro a la consolidación de un modelo económico. Al mismo tiempo se han desarrollado procesos que han tendido al cambio en las relaciones al interior de la sociedad, se propone la democratización de las relaciones sociales lo que permitiría un avance en los procesos de transformación del Estado - Nación único, a uno que incorpore la diversidad existente que constituye la nación.

En el marco de la globalización económica y cultural, el país no sólo se ha incorporado a los procesos que apuntan a consolidar una economía neoliberal, sino también en los últimos veinte años los esfuerzos han estado orientados a la democratización de espacios y relaciones al interior de éste. Se han asumido políticas que se basan en la "modernización" del Estado, lo que se ha traducido en un cambio en las relaciones entre el Estado y los actores sociales.

En este contexto de surgimiento de nuevos sujetos, de reconocimiento de éstos, se han desarrollado estrategias con el fin de mejorar las condiciones de vida de ellos. Es decir, se definen acciones, estructuras, que son dirigidas a dar solución, a incorporar la problemática de los sujetos en la estructura, para avanzar en el mejoramiento de las condiciones de vida de los sujetos emergentes. Desde esta lógica, los sujetos se constituyen en objeto de políticas sociales. Estos dbjetos son tipificados, estudiados, se establecen por tanto, categorías que facilitan o no, el acceso de éstos a los beneficios, a la estructura que ha sido establecida para la incorporación de ellos como sujetos sociales. Otro modo de observar este proceso es afirmar que, la estructura establecería distinciones, que incorporan a los sujetos a ésta, a aquellos que no eran parte de estas distinciones, los sujetos que permanecen fuera de las distinciones (no sujetos) son objetivizados, categorizados, distinguidos como sujetos - objetos de políticas sociales (9).

Las relaciones que se establecen entre el Estado Nación, las políticas sociales y los sujetos hacia los cuales se orientan éstas también nos permitirían conocer los modos en que se dan los procesos de inclusión/ exclusión, no sólo en la formulación sino también en los procesos de operacionalización de éstas. Las estrategias implementadas durante esta década han sido dirigidas a favorecer la incorporación de los sujetos a la operacionalización de las políticas, a la resolución de problemáticas; se afirma que los actores sociales debieran participar activamente en la elaboración de propuestas (proyectos), la administración de fondos asignados, la evaluación de las acciones, etc (10).

El primer gobierno concertacionista, se propuso la superación de la pobreza, como orientación de las políticas sociales, posteriormente con Frei, se definieron características de vulnerabilidad, criterio sobre el cual se han focalizado las políticas sociales, afirmando de esta manera que la pobreza afectaría de manera diferenciada a la población, las estrategias, por tanto responderían a éstas diferencias. De Laire (11) refuerza este aspecto refiriéndose al planteamiento de MIDEPLAN, "aquello que da un sello propio a la política de los dos gobiernos de la Concertación en materia de política social, debemos decir que esto ha sido conceptualizado como Enfoque de vulnerabilidad social en la Política Social.".

Los gobiernos de esta década han dirigido sus esfuerzos a través de programas enfocados a crear condiciones de vida más equitativas para la población. De Laire señala que "ello exige la aplicación de una estrategia combinada de aplicación de políticas universales y de políticas selectivas hacia sectores vulnerables (dispuesta hacia sectores vulnerables). El imperativo que orienta esta política es contribuir a corregir las situaciones de desigualdad en la base que vive una parte importante de la población, a partir de tres líneas de integración: programas de género, edad y diferencias." 


\section{Teoría de la exclusión/ inclusión}

Durante estas últimas décadas se ha hablado mucho de pobreza, marginalidad, desarrollo, desarrollo social; conceptos que han sido construidos para dar cuenta de los mecanismos, las interrelaciones, descripciones de sujetos que por encontrarse bajo determinadas características de privación social y económica, por su condición de 'vulnerabilidad', requieren ser atendidos por el sistema de servicios sociales de acuerdo a lo que se define socialmente.

Para referirme al tema de la inclusión / exclusión será necesario detenerme brevemente en dos de los conceptos que han sido utilizados por las ciencias sociales: pobreza, marginalidad, para explicar las desigualdades de acceso y distribución económica en las que se encuentra buena parte de la población mundial.

\section{Pobreza}

El concepto de pobreza ha estado asociado a una concepción más bien económica, generalmente expresado como carencia. Se han diseñado diferentes instrumentos, con el objeto de dar cuenta de las situaciones de privación de los sujetos, midiendo principalmente el acceso a determinados bienes y servicios.

En este sentido la pobreza será una característica que presenta un determinado grupo social o individuos. Por ser considerada una condición, la pobreza, aparece referida a determinados ámbitos, con características más bien estáticas. Es decir la pobreza se mide de acuerdo a ciertos estándares que se presentan como comunes para todos los individuos, incluso estas mediciones son consideradas como similares para una serie de países.

La pobreza supondría la superación de ésta, fundamentalmente por la definición de un cambio en lo económico, siendo lo económico un aspecto eje, si bien la pobreza se ha asociado a factores psicosociales, económico - estructurales, culturales. El concepto ha sido utilizado, fundamentalmente para designar la realidad de los llamados países en vías de desarrollo.

La condición de pobreza supone una serie de necesidades que no pueden ser satisfechas por oportunidades o problemas de acceso.

\section{Marginalidad}

Es posible referir dos acercamientos, uno de ellos ha sido la idea de que la marginalidad ha estado asociada a procesos de integración social y cultural, más bien anómala o deficiente de dos culturas, es decir una de las culturas sería dominada y por tanto tendería a la desaparición. La marginalidad surgiría en esta fusión, donde se manifiestan los diferentes tipos de superposición. En este sentido la marginalidad no sería un fenómeno emergente, sino un fenómeno antiguo en la historia de Latinoamérica.

En este respecto la marginación requeriría la promoción de agentes que, desde su condición de ser parte de los no marginados, generarán los mecanismos para abrir las posibilidades a los que estarían fuera.

Otra mirada es la que señala que la marginación es una condición establecida desde dentro de la sociedad. Esta tendría su origen en la estructura social, estructura que se definiría a partir de los modos de producción, los modos de diferenciación dados principalmente por lo económico y por los problemas de inserción, de ciertos sectores, al empleo. 
La marginación sería una realidad interna de la sociedad. Como producto de las diferencias, los mecanismos para su superación estarían dados por soluciones dentro de la sociedad, por un cambio en las estructuras.

\section{El concepto de exclusión/ Inclusión}

El concepto de inclusión/ exclusión, nos proporciona un acercamiento a lo social de una forma diferente. Este se constituye en un nuevo paradigma de interpretación social, el cual nos concede la comprensión de procesos emergentes de las sociedades en sus diferentes aspectos del desarrollo. Reconoce elementos y diferencias marcadas por lo territorial, cultural e histórico. Desde donde las características y particularidades responden a las realidades de determinados contextos, por tanto no es posible la generalización de la exclusión/ inclusión. Lo interesante de este acercamiento es que favorece la comprensión de procesos, donde la realidad es multicausal, la realidad pasa a ser una creación cotidiana, que se modifica y cambia.

Es relevante la aparición de este concepto, en tiempos en que el mundo, a través de la sucesión de la globalización plantea, la igualdad como principio que orienta las relaciones, en contextos de heterogeneidad, la igualdad sería posible a través de mecanismos de generación de oportunidades y derechos igualitarios. La globalización implicaría la expansión y legitimación de, por una parte, el mercado como regulador de las relaciones económicas y de la democracia como reguladora de las relaciones de poder.

El concepto ha surgido principalmente en países desarrollados, ha sido utilizado para explicar los problemas sociales, los que serían consecuencia de las reestructuraciones económicas, de cambios tecnológicos de procesos de globalización. Ha sido utilizado para referirse al fenómeno de desintegración social, en donde se ha producido un rompimiento en las relaciones, las instituciones, un cambio en donde parte de la población está dentro y la otra está fuera.

Lo interesante del concepto inclusión/ exclusión es que a diferencia del concepto de pobreza por ejemplo, el primero plantea una perspectiva multidimensional, se centra además en los procesos más que a los resultados, reconoce la heterogeneidad y especificidad de las situaciones.

\section{La inclusión/ exclusión desde una perspectiva constructivista}

La exclusión social, podría ser entendida como un "debilitamiento o quiebre de los lazos (vínculos) que unen al individuo con la sociedad"(12), lazos que permitirían a los individuos pertenecer a una sociedad o tener una identidad dentro de ésta, a partir de la cual se podría establecer una diferenciación marcada por el que los sujetos estén dentro o fuera. Estos lazos podrían ser de tres tipos, los funcionales, aquellos que permitirían la integración de los individuos al funcionamiento del sistema. Los sociales que incorporan a los individuos en grupos sociales y los de tipo cultural que permiten que los individuos se integren a pautas de comportamiento de las sociedades.

Bajo esta visión se podría decir entonces que la exclusión social, es la separación del individuo de la sociedad, que trae como consecuencia el aislamiento del mismo dentro de ella y una no participación dentro del entorno social (entendido como la red articulada de estos niveles de vínculos sociales)(13). 
Ahora bien, el tema desde una visión constructivista parece más complejo.

El binomio inclusión/ exclusión, es un concepto comunicacional más que de estratificación. Ambos conceptos son condicionados mutuamente, es decir son aspectos, lados de una misma forma, si distinguimos uno de los dos lados aparece el otro; en otras palabras es la unidad de la diferencia (14).

En relación al concepto es posible distinguir variantes. La primera de ellas, tiene un carácter más bien social, esta se relaciona con las condiciones de acceso de acuerdo a los niveles de diferenciación social, a la comunicación. La otra plantea la exclusión como la evidencia de que la inclusión no ha sido posible, no ha sido concebida, es decir la inclusión es posible como parte del proceso de acumulación respecto de los sistemas funcionales, por tanto la exclusión estaría determinada por las dificultades para acumular estos mecanismos; otra posibilidad dentro de este aspecto es aquella que se abre a través de los sistemas de asistencia social, los sistemas funcionales que intentan aumentar las posibilidades de acumulación de mecanismos de inclusión. Una tercera variante es la posibilidad de ocupar este concepto con el fin de dar cuenta de la cohesión social, mediante la exclusión, es decir, el modo en que se configuran los mecanismos, los perfiles que permiten en la exclusión, la cohesión social. Otro modo de visualizar el concepto es la idea de que es posible detallar los componentes de cada uno de los aspectos, describir las asimetrías, los contrastes que hacen probable estar dentro o fuera, este modo de acercamiento presenta sus dificultades, ya que depende de donde se observe, el otro aspecto conformará el entorno. Una quinta variante es situarse desde la relación sociedad/ individuo, en donde no se considera la participación del individuo sino más bien el lugar de éste en la descripción de la individualidad. Otro modo de acercarse es la variante que considera la relación, sistema psíquico y sistema social, desde este contexto la inclusión/ exclusión sería una forma de domiciliaridad, desde cada uno de los aspectos incluidos habría una suerte de perfil. Finalmente desde una extensión más bien teórica, se desacopla el concepto de diferenciación social y lo aplica a los sistemas funcionales y a los sistemas de interacción; es decir podríamos afirmar que en la interacción los individuos participan en la comunicación, el que participe de ella está incluido; en el nivel de las organizaciones la inclusión está dada por la membresía de los individuos en las organizaciones (15). Como vemos resulta más bien complejo un único acercamiento al concepto; es un concepto que no puede ser utilizado para referirse a totalidades, ni para intentar explicar generalidades, permite más bien una nueva comprensión de lo social desde la complejidad de la heterogeneidad, la multiplicidad de relaciones y comunicaciones que se establecen socialmente.

Quisiera volver sobre la idea de forma. Un concepto puede ser definido, en cuanto es posible también distinguir aquello que excluye. Cuando decimos que la inclusión/ exclusión es un concepto binominal, en su estructuración nos permite acercarnos a su unicidad. Al acercarnos a una de sus partes, al distinguir, distinguimos una de las operaciones; de acuerdo a Spencer Brown, "una operación es una indicación distintiva se convierte en observación. Las observaciones indican uno de los lados de una distinción presuponiendo que hay otro" (16). El autor acuña la idea de forma para referirse a que las observaciones, en tanto operaciones, indican cada uno de los lados de la distinción. Siguiendo este razonamiento podemos decir que al observar un sistema, estamos a su vez refiriéndonos a su entorno, desde la idea del sistema como forma, desde un observador que realiza las distinciones.

De otro modo, al observar un sistema estamos realizando distinciones que elaboran diferenciaciones, o sea forman sistemas dentro de un sistema, en donde las características de la relación permitirán dejar fuera otras diferenciaciones. Ejemplo de tipos de diferenciación, son la estratificación y la diferenciación funcional. Para referirse a las formas de diferenciación en 
las sociedades modernas, Luhmann, se detiene en la descripción de la inclusión/exclusión en las sociedades segmentarias y en las sociedades estratificadas.

La inclusión, en las sociedades segmentarias, es producto de la "agregación a determinados segmentos de la sociedad" la agregación se producirá a través de unidades menores de la comunidad, la familia y la residencia. La exclusión se producirá, al generarse un hecho fortuito, el destierro, el traslado, etc. En este tipo de sociedades se requiere estar incluido en algún segmento.

En las sociedades estratificadas, "la inclusión sigue también el principio de la diferenciación”, se formará parte de una sociedad en la medida que se constituya parte de un estrato. También es posible pertenecer sólo a un subsistema y no a varios. La individuación es adquirida a través de la asignación de status social. En este tipo de sociedades, en la medida que se complejizan las estructuras, los mecanismos de reconocimiento se complican, la inclusión tendrá consecuencias jurídicas, se dará por la pertenencia a una familia, a determinado estamento, así como también estará marcada por la residencia, por la interacción regulada, por la permanencia en un lugar. La exclusión estará señalada por un cambio en el subsistema y por sobretodo la separación de los individuos de un hogar. La exclusión (en la edad media principalmente) queda determinada por una ruptura de la reciprocidad. Luego en los comienzos de la edad moderna, la inclusión lexclusión no sólo estará referida a individuos sino también a grupos, es decir, la familia, la casa ya no tendrán como función la exclusión/ inclusión. La inclusión, resulta como principio de diferenciación social, principio definido como interno a la sociedad.

La sociedad funcionalmente diferenciada, la sociedad moderna, de acuerdo a Luhmann, tendería a renunciar a una regulación uniforme de la inclusión. Se confía la inclusión social a los sistemas funcionales, a la regulación autónoma de éstos.

"La sociedad funcionalmente diferenciada es capaz de producir y tolerar desigualdades extremas en la distribución de los bienes, tanto privados como públicos" (17). Esta manera de comprender contiene dos tipos de restricciones, por un lado la temporalización, en donde se ve como un fenómeno posible de ser modificado y discontinuidades de la interdependencia, o sea como fenómeno limitado a ámbitos concretos funcionales, interponiéndose limitaciones en su interdependencia.

El autor señala que la inclusión/ exclusión es más bien una distinción interna del sistema, que puede ser aplicada en el orden de la comunicación. La exclusión sería lo que permanece no indicado, cuando se considera o se señala la inclusión, "la inclusión es como un efecto secundario de la operación autodescriptiva, al igual que toda fijación de una identidad desconsidera algo que no le pertenece" (18).

En este sentido, en las sociedades de la periferia la exclusión y las inclusión se constituyen en funciones primarias de la diferenciación social, es decir existirá población que quede fuera de los sistemas funcionales. Este tipo de exclusión, en donde las personas que están fuera acceden al sistema bajo las condiciones y expectativas que el sistema social configura, se denomina "exclusión primaria" se "entenderá entonces que no se puede acceder a los sistemas funcionales que puedan significar inclusión a prestaciones y servicios elementales" (19).

Retomemos la idea de inclusión/ exclusión, de acuerdo a lo señalado por Luhmann. La ruptura de las reciprocidades entre las personas, como resultado de una política legitimada en las sociedades de la periferia moderna, ha dado como resultado la exclusión. La observación de la exclusión conduce a que en la exclusión no habiten personas, en la medida que la 
diferenciación opera desde la asignación de estatus, es decir se pertenece a las sociedades en la medida que se pertenece a los estratos de los incluidos, cerrándose a la exclusión.

La exclusión secundaria, se "entenderá entonces que no se puede acceder a las redes interaccionales de influencia", es decir, en los contornos de la relación inclusión/ exclusión funcionan redes de inclusión as que pueden ser, redes de favores, de influencias, o sea contactos interaccionales, a los que los sujetos no podrían acceder.

En la definición que F. Robles desarrolla, afirma que "inclusión y exclusión no sólo se reproducen y sedimentan, sino que además de condicionarse originan formas propias de conectividad", en donde las personas no sólo se ubicarían en uno de estas distinciones sino que también podrían deambular de uno a otro lado.

La exclusión, es el resultado de lo que la sociedad describe, efecto de la operación autodescriptiva, por tanto no está en relación a la idea de que los sujetos sean o no parte de la sociedad, esta pertenencia estará más bien dada por la ubicación del observador en la descripción, por tanto podemos afirmar que es posible situarse desde el lado de la exclusión, para dar cuenta de ella.

\section{Individuación e individualización, inclusión/ exclusión}

En el marco de los procesos sociales y de la comprensión de las estructuras sociales, se releva la importancia de comprender los mecanismos de individuación asociados a la vulnerabilidad. La inclusión/ exclusión de las estructuras sociales está asociada a los procesos de construcción de los individuación e individualización. La diferencia entre ambos conceptos radica en: "individuación como la configuración de la individualidad en las sociedades industrializadas y la individualización, como la forma específica de configuración de la individualidad en los países de la periferia globalizada: la autoconfrontación consigo mismo en medio de unidades específicas de socialización, en el caso de la individualización es un proceso de autoconfrontación asistido, mientras que el capitalismo periférico se trata de una autoconfrontación desrregulada, y significa por lo tanto un aumento significativo de las inseguridades ontológicas. Condicionadas por el empleo precario, la subcontratación, las antinomias de las relaciones de trabajo, las diferenciaciones de género, etc. dicha desregulación es el producto de la distinción entre inclusión/ exclusión, la que se puede reconocer por la ruptura de las reciprocidades; dicha distinción entre dentro (inclusión) y fuera (exclusión) obedece a una política explícita de diferenciación social, la que abre abismos infranqueables y 'tiende a asumir la función de una diferenciación primaria de la sociedad" (20).

En este entendido, las "significaciones colectivas se agotan, se quiebran, se desencantan. Todos los esfuerzos y las responsabilidades de definición recaen en los sujetos, en los individuos" (21).

\section{EI Estado. Relación Estado/ sujetos}

Hasta el momento me he referido a los principales conceptos que están contenidos en el presente estudio. Las reflexiones y aproximaciones teóricas permiten afirmar que las interpretaciones culturales de los sujetos y las relaciones que establecemos, se traducen en acciones y consecuencias que afectan en la vida cotidiana a los sujetos sociales. Muchos de estos mecanismos como ya hemos visto se encuentran legitimados e institucionalizados produciendo fenómenos de retroalimentación de procesos de inclusión y exclusión. Más 
adelante me detendré sobre algunas cifras y antecedentes que permiten graficar la situación de inclusión/ exclusión social de mujeres y personas con discapacidad en nuestra sociedad.

La temática del Estado subyace y está presente en las políticas sociales. Creo de importancia detenerme sobre algunos planteamientos que vinculan al Estado y las representaciones o los procesos de relacionados con la construcción de representaciones, estereotipos, por una parte y por otra, de la significación de las acciones implementadas por el Estado. La primera aproximación la realizaré a partir de los planteamientos de M. Herzfeld (22) acerca de la producción social de la indiferencia y M. Foucault (23) en torno al tema del gobierno de las mentes.

Los planteamientos de M. Herzfeld se centran en la idea de que las representaciones son utilizadas por el Estado, como mecanismos de control, en particular entre aquellos que laboran en las instituciones u oficinas del Estado; éstas son reconocidas como la "burocracia nacional". A través del Estado y su estructura se reproducirían determinados fenómenos.

Para adentrarse en este planteamiento resulta importante señalar que el autor cuestiona, a través de su trabajo, la idea de que exista un modo común y uniforme de estructurar y resolver lo que connotamos como lo occidental. En este sentido indica que existiría una idea errónea que afirma la prevalencia de un modo común, una cultura compartida bajo el concepto de lo occidental. Esta idea, lo occidental estaría relacionada con la imagen de identidad y a un modo burocrático de manejar la identidad, no sólo personal, social, sino también nacional. En este sentido es posible distinguir determinadas acciones que se basan en la afirmación de que existiría un "carácter nacional". A partir de este, la burocracia tendría como objetivo de acción, el construir y definir identidades nacionales. La burocracia, emerge cuando se contrastan nuestro ideales y expectativas en torno al Estado y nos enfrentamos a los modos de operar de éste; es decir, cuando vemos que el garante de nuestros derechos no está asegurando éstos a través de su accionar.

Los símbolos y la conexión entre éstos se constituyen en poderosas formas potenciales o concretas de manipulación, de acuerdo a lo señalado por el autor. De otra manera, los símbolos que se naturalizan se constituyen en elementos que la burocracia puede utilizar para sostener la cohesión y la obediencia. Esto es posible en la medida que se establece y refuerza la idea de una identidad común, es lo que se define en la idea del carácter nacional.

En este entendido los elementos que se significan socialmente pueden tanto incluir o excluir a los sujetos de los procesos sociales. A la vez resulta importante la idea de que los símbolos tienden a modificarse, lo que permite sostener las relaciones que se establecen a partir de ellos, es decir la flexibilidad de éstos perpetúa las relaciones de desigualdad (24).

Para el autor la convención entre los estereotipos y las prácticas permiten la existencia y reproducción del aparato burocrático. A través de sus estudios profundizó en la significación de la relación de consanguinidad, la sangre definido como inicio de códigos morales, así como forma de clasificación de las personas. La clasificación permitirá un orden, por tanto, el cruce de elementos o categorías será una amenaza, esto es claro en la idea de nacionalismo y el esfuerzo por unificar y establecer categorías únicas y puras de modo de mantener el orden establecido. La identidad, indica, no sólo estaría asociada a algunos elementos como por ejemplo la sangre, sino también a las guerras y lo intelectual, al conocimiento; estas ideas han estado asociadas a las definiciones de personas. Desde allí, afirma tras la noción de nacionalismo existiría una lógica que asocia la idea de nación con la idea de familia. Sobre ésto 
se sentarían las nociones de estructuras y las relaciones al interior de los países y de éstos con otros.

"Burocracia, de acuerdo a Weber, es el sistema demandando accountability, y accountability, es socialmente producida, culturalmente es una amalgama de ideas saturadas acerca de las personas, presencia y polis (polity). A pesar de que se habla de una racionalidad universal, ésta tiene manifestaciones y significados culturales específicos, y sus operaciones son contenidas en los modos en los que tanto operadores y clientes interpretan sus acciones. El manejo de la identidad colectiva y personal no puede ser quebrantada por la experiencia social (25). Es decir la burocracia no puede ser vista como un aspecto racional y objetivo, es necesario reconocer los aspectos sociales y culturales contenidas en ella, no sólo en lo individual sino también en lo social, en donde también confluyen aspectos relacionados con las intenciones, propósitos e identidades. La burocracia es una convención, en donde se establece la relación entre las intenciones de uso y las tácticas de mantención del poder, así como la humillación y la indiferencia, actitudes que se definen en convenciones socio culturales. En este sentido no es posible desentenderse de la experiencia social, los modos de actuar tanto en lo personal, como en la identidad social.

En esta misma línea el autor señala que existe una estrecha relación entre las manifestaciones de poder de parte del Estado y los diferentes niveles que la comunidad reconoce. La intolerancia así como la indiferencia oficial se basan en actitudes populares, más que en discursos oficiales construidos. La retórica en este contexto no es sólo una forma de clasificación, sino más bien se relaciona con las prácticas de las acciones simbólicas, en donde completar un formulario no es sólo una formalidad, sino que determina las condiciones y los significados. Los estereotipos, no son la construcción de categorías sociales sino categorías retóricas en uso, como "representaciones del inquietante cambio en las relaciones sociales".

Los estudios realizados por M. Herzfeld se han orientado a describir no sólo los estereotipos contenidos en los procesos burocráticos, sino también se han centrado en dar cuenta en la íntima relación que existe entre los estereotipos socialmente compartidos y las clasificaciones burocráticas. Señala que los estereotipos de la burocracia no existen en la forma de aspiración social sino que emergen de la relación entre actores que cuentan con poder, la estructura de la lógica de razonamiento es definida por las circunstancias.

La burocracia se constituye en una suerte de instructivo tautológico, las cosas se harán de determinado modo porque es el modo en que es. Los burócratas, señala el autor, frecuentemente arguyen, al momento de explicar arbitrariedades, acciones y decisiones injustificadas, explican que éstas se deben a razones que van más allá de ellos mismos, que dependerían del sistema, es éste el responsable final de las acciones.

Retrocediendo sobre la idea de la retórica, ésta contendría una fuerza en sí misma. La retórica no es sólo un fenómeno relacionado al poder, sino se constituye en la clave de la producción de la indiferencia, en las burocracias del Estado Nación.

Los estereotipos, incluso definen y ajustan a un determinado orden y comportamiento a los burócratas. Estas definiciones, los estereotipos y los modos de relacionarse, cambiarían de acuerdo al contexto cultural en que operen. Es decir los estereotipos que describen a un burócrata en un país y en otro estará determinado por la "sangre", por las relaciones de consanguinidad que son las que determinan desde el sistema cultural los incluidos o los excluidos. Los estereotipos traducen en las prácticas burocráticas un modo común, que transgrede las fronteras del sistema estatal, que está contenido y está a su vez en los otros 
sistemas. En este sentido la identidad nacional provee las orientaciones para las prácticas burocráticas.

La idea o metáfora de la consanguinidad, es posible de extender a diversas entidades sociales, en el contexto del discurso nacionalista: es decir grupos étnicos, grupos locales, religiosos, profesionales, de clases sociales, etc. En este sentido los argumentos relativos al nacionalismo se tornan en entidades culturales más que sociales, a pesar de que las relaciones y estatus se articulan en torno a la exclusividad social. En la idea de consanguinidad se sientan las bases de la exclusión.

Las leyes en este entramado se constituyen en un modo de institucionalizar los estereotipos, por tanto las relaciones.

Los estudios realizados por el autor, dan cuenta de que los estereotipos se constituyen en justificaciones de la indiferencia, las acciones de los burócratas estarán respaldas por la argumentación de que el sistema es quien finalmente está tras el estereotipo. "Las acciones calzan con los estereotipos, los estereotipos calzan con las leyes".

La ley es un recurso incambiable de la autoridad, la conflagración del lenguaje y el cuerpo. De acuerdo al autor, la ley es como el idioma nacional, en donde la ley es el garante y ejecutor, que se convierte en objeto de veneración en las prácticas burocráticas, es un símbolo y material ritual con los cuales los burócratas conjugan para convertir la incomodidad e inconveniencia en objetivos de poder personal.

\section{El gobierno de las mentes.}

A la hora de observar las estructuras, un planteamiento importante es el elaborado por Foucault, éste a través de sus trabajos y reflexiones afirma que los gobiernos y las estructuras dan cuenta y responden a intereses particulares. Los estudios realizados por Foucault ponen en evidencia lo que llamó la actividad o el arte de gobernar, a través de ellos descubre los modos en que ha sido pensado y practicado.

En este entendido, el gobierno en la idea no sólo es la representación o poder o autoridad que se tenga para ser legitimado, sino que, éste contiene una intencionalidad, en donde la crítica y cuestionamiento a estos pondría en cuestión, tanto los modos de pensar como las prácticas. En otras palabras, el arte de gobernar o la racionalidad del gobierno, están contenidas tanto en las ideas como en las acciones, de allí la importancia de conocer las acciones y las formas en que estas deben ser llevadas. "La racionalidad de gobernar, la entenderemos como, el modo o el sistema de pensamiento, acerca de la naturaleza y la práctica del gobierno (Quien puede gobernar, que es gobernar, y que o quien es gobernado), es la capacidad de hacer que algunas formas del gobierno sean practicables tanto por aquellos que practican el gobierno como aquellos sobre los cuales éste es practicado" (26).

Acerca del Estado el autor plantea, que no concuerda con las teorías que señalan que el Estado se preocupa de sus propiedades y particularmente tiende a incorporar o colonizar todo aquello que se encuentre fuera de él; al respecto señala que el Estado no posee esos propósitos, sino más bien el Estado tiene la función de cambiar las prácticas de gobierno, más que conversar. Señala que las teorías políticas tienden a mirar en demasía las instituciones y muy poco a las prácticas de ésta. 
El gobierno para Foucault está definido, "como la actividad que puede concernir la relación entre un sí mismo y otro, las relaciones privadas que incluyen algún tipo de control u orientación, la relación entre las organizaciones y algunas instituciones o comunidades y finalmente la relación que concierne al ejercicio de la soberanía política" (27).

El autor establece ciertas distinciones respecto del proceso histórico en el cual ha sido observado el acto de gobernar. Señala a través de la historia el acto de gobernar ha sido visto y estudiado de diversas maneras. Al Estado están asociadas algunas ideas, como las formas cristianas, en donde el Estado ha sido subordinado a lo divino, a un orden teológico del cosmos, o la idea de la prosperidad y la felicidad, como principio que identifica a los sujetos con el Estado. Por otro lado se ha asociado una idea universalista, como política de gobernar, en donde se define para todos y para cada uno, una asignación universal en la idea de la utilidad de la vida. (diferentes etapas de la historia). En arte de gobernar es racional, indica que es importante mirar la naturaleza de "que" es gobernado, el Estado, la razón de este, es gobernar de acuerdo a su propia fuerza.

Un aspecto importante señalado por Foucault, en el tema de gobernar, es pensar en cómo resulta posible establecer una continuidad del gobierno y sus formas más allá de quién gobierna. Desde allí existiría una conexión esencial entre uno y otro gobernador.

La forma de concebir el gobierno ha variado desde la idea de soberanía, como fin en sí misma, soberanía sobre las cosas, los territorios, de mantener el control y posteriormente en la idea gobernar a la población. En donde la economía se sustenta en el gobierno de las familias, de éstas respecto al trabajo, de éstas en su relación con la economía, como ejercicio del poder de acuerdo y respecto al modelo económico. Con relación a esto, señala que la idea no es oponer las cosas a las personas sino ver éstas en su relación con ellas, es decir la relación, la imbricación que existe entre las personas y los recursos, el significado de la subsistencia, el territorio, el clima, la salud, etc. las personas en su relación con otras cosas, como éstas se relacionan contienen una relación con la muerte, las epidemias, con los hábitos, costumbres etc.

En síntesis el selfgovernment, el gobierno de sí mismo, se relaciona con la moral. La economía en relación al gobierno de la familia, y el Estado respecto a la política.

Bajo la idea de governmentality, gobierno de la mente, el autor destaca a lo menos tres elementos:

1. La relación entre las instituciones, los procedimientos, el análisis, las reflexiones, el cálculo, las tácticas, que permiten el ejercicio, a pesar de, una forma específica de poder, sobre la población. Una forma de poder, como la principal forma de conocimiento de la economía política y en lo esencialmente técnico, lo que se refiere a los aparatos de seguridad.

Es decir, es el ejercicio del poder a través de la economía y el cómo se ejercita este poder está determinado técnicamente, por medio de las diferentes estrategias y formas de control, que permiten la "sensación de seguridad".

2. En occidente, a lo largo del tiempo la tendencia ha sido la dominación. La preeminencia, por sobre otras formas, como la soberanía, la disciplina, y otros tipos de poder, que pueden ser definidos como gobierno, pero que resultan, por una parte, en la formación de un conjunto de series de aparatos de gobiernos de las mentes, y por otro lado en el desarrollo de "salvadores" de características más bien complejas. 
Es decir a lo largo del tiempo se ha asentado un proceso de dominación, el sistema se ha fortalecido.

3. Como proceso, como resultado del proceso histórico relacionado como tal. A través del cual el Estado de justicia en la edad media, transformado en un Estado administrativo entre los siglos 15 y 17, perpetúa el poder y el control hacia el gobierno de las mentes (28).

El Estado de Justicia emerge en los tiempos feudales, lo que corresponde a una sociedad de leyes, tanto las leyes escritas como las costumbres, que contenían un conjunto de obligaciones, reciprocidades, y litigios; en un segundo momento, el Estado administrativo, nacido en las fronteras de lo nacional entre el siglo 15 y 17, que corresponde más bien a una sociedad que regula la disciplina, y finalmente el Estado del gobierno de las mentes, definido no sólo respecto al territorio o sector, sino definido en términos de la población, en cuanto al volumen, densidad, y por cierto el territorio a través del cual ésta es distribuida. Este gobierno del Estado se relaciona esencialmente con la población, refiere y hace uso de los salvadores económicos, y que pueden ser vistos como un tipo de sociedad controlada por los aparatos de seguridad.

En la historia de Occidente, la pastoral (como modelo Cristiano), las nuevas técnicas diplomáticas y militares y también los aparatos de seguridad, han hecho posible la producción de la gobvernmentalization of the state (el gobierno de las mentes del Estado).

La idea fundamental señala que los discursos y las practicas lo que pretenden es orientar, dirigir las acciones, a través de dirigir las conductas de las personas. El gobernar estará asociado al modo de dirigir o regular las acciones.

\section{Relación entre políticas sociales y los movimientos sociales.}

A continuación me detendré en el proceso de generación de políticas sociales en nuestro país, para ello será necesario retroceder en la historia de cómo determinadas temáticas, problemas sociales se instalaron tanto en el discurso como en la estructura estatal.

En la década de los 70 y los inicios de los 90 los países de nuestra región se encontraban en diferentes procesos en torno a la recuperación de relaciones democráticas al interior de cada sociedad.

El camino de recuperación de la democracia en nuestro país tuvo como primer resultado consolidador el triunfo del $\mathrm{NO}$ en el proceso definido por Pinochet para la continuidad de éste en la conducción del país.

La movilización de la población a través de diferentes agrupaciones, partidos políticos, etc. fue de vital importancia para distinguir como sociedad la presencia de determinados sujetos en la historia nacional. Estos grupos y sujetos se fueron articulando en torno a sus derechos, así como a la recuperación de la democracia.

La nueva forma de estructurar el Estado conlleva el establecimiento de una nueva relación entre sociedad civil y la estructura estatal.

En el contexto de la neoliberalización del Estado, cambia no sólo el modo en que se concibe la relación del Estado y la sociedad, sino también los modos en que se define la intervención social. Lo que conllevara significantes efectos sociales. De acuerdo a lo afirmado por Schild, el 
Estado es el centro de las preocupaciones de los procesos de modernización, lo que se ha llamado el proyecto neoliberal.

Parte importante de este proceso de modernización del Estado ha sido la redefinición de la ciudadanía, de la participación, así como la autonomía económica.

Si relacionamos lo señalado por Foucault con la emergencia de nuevos procesos sociales y al mismo tiempo, los procesos y nuevas acciones del Estado, podría señalar que éste se constituiría en un nuevo articulador de identidades en la medida que sus acciones no sólo tienen un impacto en lo social, sino también en ámbitos más subjetivos y simbólicos de las personas.

\section{Demandas y necesidades de la población y el Estado}

El cambio en el Estado, implementado durante los 70 y 80 , desde la política pública, con la idea de abordar el tema social desde una mirada diferente, establece una transformación desde un Estado benefactor a uno de carácter subsidiario. Para adentrarse en este nuevo modo de enfrentar lo social, se llevan a la práctica políticas de focalización, lo que se tradujo en un modo diferente no sólo de agrupar las necesidades y a los sujetos sino también a un modo diferente de entrega financiera de éstos, de una entrega directa de los subsidios, a través de programas masivos y universales, se pasó a la entrega de subsidios directos a la demanda, lo que significó un cambio, es decir se operó bajo la idea de la focalización no sólo territorial, sino se definieron parámetros con que definir a la población.

Con respecto a las estrategias desarrolladas durante los inicios y posterior desarrollo de la década de los noventa, cabe destacar que la política social se ha caracterizado por un enfoque de vulnerabilidad social. Bajo la idea de la equidad, se desarrollan diferentes programas orientados a disminuir las diferencias sociales y a satisfacer las necesidades de la población. Se continua con la aplicación de políticas de carácter más bien universal, pero al mismo tiempo se desarrollan acciones de carácter más local o sectorial, más orientadas a sectores específicos.

Asumiendo la importancia de asegurar la equidad, se crea el Ministerio de Planificación y Cooperación, del que a su vez dependerán servicios, corporaciones y fondos. Cada una de estas estructuras se constituyó en la idea de atender priorizadamente a un sector, grupo o sujeto, la diferenciación de estos grupos, de acuerdo a edad, diferencias, vulnerabilidad en el proceso de satisfacción de necesidades y mujeres. De Laire en cambio distingue "edad, género, diferencias étnicas o de capacidad física o mental; localización geográfica; situación de vulnerabilidad en el proceso de satisfacción de necesidades". Procesos impulsados con una mirada intersectorial y también territorial, contenida en los procesos de regionalización y modernización del Estado.

Ahora bien quisiera detenerme en la definición y constitución de las estructuras, necesidades de los sujetos, actuales focos de atención de las políticas desde las estructura del SERNAM y FONADIS.

El movimiento social, generado durante la dictadura militar que recupera importancia política a fines de esa década, permite impulsar en parte importante las políticas sociales que posteriormente asume el primer gobierno de la Concertación a lo que por cierto se suman acuerdos y convenciones internacionales firmadas incluso por el gobierno militar. 
Los procesos de instalación de las temáticas relativas a los sujetos mujeres y personas con discapacidad se detallarán en la parte correspondiente a la descripción de casos que a continuación desarrollaré.

Considerando los elementos anteriormente reseñados, una aproximación constructivista de los procesos socioculturales será posible, a través de un metodología pertinente, un acercamiento a la elaboración de representaciones socioculturales que realizan las políticas sociales acerca de los sujetos emergentes, en el contexto de las políticas y estructuras orientadas a los nuevos sujetos.

\section{DESCRIPCION DEL ESTUDIO DE CASOS}

En esta parte se detallarán las características de los casos seleccionados, la estructura que los diferencia, las características legales, que les habilitan o no, para constituirse en hacedores de políticas sociales en relación a los sujetos a los cuales se orientan sus servicios. Se describirá a cada uno de los casos, las características de los equipos, la documentación seleccionada, etc., para ello trataré los aspectos relevantes para el estudio.

El estudio pretende entregar una aproximación de carácter exploratoria acerca de las representaciones de los/ las hacedoras políticas sociales, acerca de las mujeres y personas con discapacidad.

Con el fin de obtener información en torno a la temática, me plantee la necesidad de revisar la estructura que emerge para hacerse cargo de las problemáticas vinculadas a mujeres y personas con discapacidad. Como señalé en la presentación la estructura elaborada en la década de los noventa en Chile, fue diseñada con la lógica de la focalización, sobre la edad, las diferencias y género (29). Cada una de estas problemáticas fue abordada por estructuras diferentes, que a lo largo de los gobiernos de la Concertación han ido definiendo énfasis y estrategias de trabajo de acuerdo a la estructura que poseen.

A continuación señalaré brevemente algunos aspectos relevantes asociados a la problemáticas así como a las instituciones y sus características.

\section{MIDEPLAN. Ministerio de Planificación y Cooperación.}

El Ministerio de Planificación y Cooperación se desprende de la Oficina de Planificación Nacional (ODEPLAN). ODEPLAN se caracterizó por ser un servicio de carácter público descentralizado, con un patrimonio propio, dependiendo directamente del Presidente de la República a través del Ministerio del Interior, pudiendo además establecer Oficinas Regionales de Planificación en los lugares que el Director estimara conveniente.

En el año 1974, por causa del Decreto Ley № 573, las Oficinas Regionales de Planificación cambian de nombre, estableciendo una Secretaría Regional de Planificación y Coordinación, que estará más integrada al sistema nacional de planificación, cumpliendo con el objetivo de: "servir de organismo asesor y de secretaría técnica del Intendente Regional y del Consejo Regional de Desarrollo, con las facultades y deberes que señale la ley" (30).

Posteriormente, en el año 1990 la Oficina de Planificación Nacional se transforma en el Ministerio de Planificación y Cooperación por la Ley 18.989, la cual en su artículo primero define al MIDEPLAN como "una Secretaría de Estado encargada de colaborar con el Presidente de la 
República en el diseño y aplicación de políticas, planes y programas de desarrollo regional, de proponer las metas de inversión pública y evaluar los proyectos de inversión financiados por el Estado, de armonizar y coordinar las diferentes iniciativas del sector público encaminadas a erradicar la pobreza y de orientar la cooperación internacional que el país reciba y otorgue" (31).

A partir de la estructura y el objetivo orientador del Ministerio se crearon en períodos y condiciones diferentes, estructuras dependientes de éste, que se hicieron cargo de las temáticas emergentes principalmente ligadas a la pobreza. Lo interesante de esta estructura es que se plantea la identificación y propuesta, a través de estudios e inversión, de políticas globales y sectoriales del Ministerio y del sector público.

Del Ministerio de Planificación y Cooperación dependen a su vez con los siguientes organismos:

- Fondo de Solidaridad e Inversión Social (FOSIS)

Este tiene por finalidad: "financiar en todo o parte, planes, programas, proyectos y actividades especiales de desarrollo social, los que deberán coordinarse con los que realicen otras reparticiones del Estado, en especial con el Fondo de Desarrollo Regional. Estará sometido a la supervigilancia del Presidente de la República, con quien se relacionará por intermedio del Ministerio de Planificación y Cooperación" (32).

- Agencia de Cooperación Internacional (AGCl)

Su función tiene que ver con la administración de recursos de cooperación internacional con el fin de apoyar proyectos, planes, programas actividades de desarrollo, los cuales sean impulsados por el gobierno. Se somete a la supervigilancia del Presidente de la República a través del Ministerio de Planificación y Cooperación.

- Servicio Nacional de la Mujer (SERNAM)

Ley NN19.023, M. Del Interior - Diario Oficial 3 Enero 1991.

Este será un servicio público, descentralizado que posee patrimonio y personalidad jurídica propios. Su relación con el Presidente de la República estará dada por el Ministro de Planificación y Cooperación. Según el artículo $2^{\circ}$ de la Ley 19.023: "El Servicio Nacional de la Mujer es el organismo encargado de colaborar con el Ejecutivo en el estudio y proposición de planes generales y medidas conducentes a que la mujer goce de igualdad de oportunidades respecto del hombre, en el proceso de desarrollo político, social, económico y cultural del país, respetando la naturaleza y especificidad de la mujer que emana de la diversidad natural de los sexos, incluida su adecuada proyección en las relaciones de la familia" (33).

- Instituto Nacional de la Juventud (INJ)

Ley N¹9.042, M. De Planificación y Cooperación - Diario Oficial 16 Febrero 1991

Se caracteriza por poseer personalidad jurídica y patrimonio propio, siendo funcionalmente descentralizadas. Su función tiene que ver con el diseño de políticas públicas relacionadas con los asuntos juveniles.

- Corporación Nacional de Desarrollo Indígena (CONADI)

Ley N¹9.253 M. De Planificación y Cooperación - Diario Oficial 5 Octubre 1993

Institución del Estado, cuya función será la de promover, coordinar y ejecutar la acción del Estado a favor del desarrollo integral de las personas y comunidades indígenas, sobre todo en lo que respecta a lo económico, cultural y social. Además la CONADI se preocupará de impulsar su participación a nivel nacional. 
- Fondo Nacional de la Discapacidad (FONADISL

Ley N 19.284. M. De Planificación y Cooperación - Diario Oficial 14 Enero 1994

Su misión es: "contribuir a la inserción social y a la equiparación de oportunidades para las personas con discapacidad, mediante la administración eficiente de los recursos financieros que se ponen a su disposición. Reúne en su Consejo a miembros del gobierno, delegados de asociación de discapacitados frecuentes, instituciones sin fines de lucro, representantes del sector empresarial y laboral" (34).

\section{SERNAM. Servicio Nacional de la Mujer.}

Para adentrarnos en la temática de las mujeres, será necesario en un primer momento dar cuenta de la estructura institucional encargada de velar por la problemática de las mujeres, para luego definir alguna de las principales problemáticas que afectan a las mujeres.

\section{El proceso de instalación de la temática en la estructura}

La emergencia del tema de las mujeres, está situado de la mano de diversas organizaciones no gubernamentales, organizaciones y otras que centraron parte importante de sus acciones en el desarrollo de intervenciones, estudios y desarrollo de metodologías de trabajo durante los ochenta. Parte vital de estas fuerzas sociales se tradujo en la instalación de temáticas ligadas a las mujeres y también al género. En otras palabras a través de este proceso se instaló la temática de las mujeres en el Estado.

Con el triunfo del "no" en el plebiscito de 1988, diversas mujeres, provenientes de mundos

diferentes constituyeron la Concertación Nacional de Mujeres por la democracia. Para éstas, la primera tarea fue la instalación de la problemática de las mujeres en el contexto nacional, además de desarrollar una propuesta para el futuro gobierno democrático, así como el trabajo para el proceso previo a éste. Para ello se implementaron diversas comisiones con el fin de trabajar propuestas puntuales que giraron en torno a temáticas específicas.

Los trabajos se centraron en la presentación de un diagnóstico y de políticas que reflejaran las diferentes opiniones y posturas frente a temáticas relativas a las mujeres. La propuesta recoge temas como salud, educación, familia, comunicaciones, arte y cultura, empleo, participación política, campesinas, pobladoras, legislación y la propuesta centrada en la conformación de la "Oficina Nacional de la Mujer", a partir de esta serie de propuestas se articula la generación de la institucionalidad que abordará la temática de la mujer a nivel de la estructura del Estado y de las propuestas de los gobiernos.

El Servicio Nacional de la Mujer, es creado en 1991, a través de la Ley 19.023, cuenta con personalidad jurídica, con presupuesto propio, la dirección del servicio tiene rango de Ministro, por lo que participa directamente con el poder ejecutivo. La misión del Servicio es colaborar con el Poder Ejecutivo en el diseño y coordinación de políticas públicas que pongan fin a los niveles de discriminación que afectan a las mujeres, tanto en el ámbito familiar, social, laboral, económico y cultural.

En las trece capitales regionales se cuenta con una organización dependiente del Servicio, a su vez el servicio cuenta con diferentes unidades o departamentos encargados de desarrollar programas regionales, capacitación, coordinación con otros servicios públicos, elaborar reformas legales, estudios y planificación y evaluación de las estrategias desarrolladas. 
A través de los diagnósticos realizados ha sido posible no sólo conocer la situación de las mujeres, sino también ha sido posible la visibilización de determinadas problemáticas que afectan las mujeres, lo que ha permitido la modificación de la estrategias implementadas (35).

La elaboración de los planes de igualdad de oportunidades han permitido instalar transversalmente temáticas y orientaciones que definen la acción del Estado con respecto a la temática de la mujer desde áreas diferentes. El primer plan (1994- 1999) se enmarca en los lineamientos del gobierno que señala como "imperativo el superar la situación de discriminación de la mujer. Ello es una exigencia ineludible de la profundización democrática, del desarrollo económico del país y del esfuerzo modernizador, ejes fundamentales del actual período" (36). El plan es parte importante del gobierno de E. Frei Ruiz-Tagle, a través de éste se pretende contribuir al programa del gobierno de la Concertación, definido sobre los pilares de profundización democrática, modernización del país, desarrollo, superación de la pobreza. Por otra parte apunta a dar cumplimiento a los acuerdos y convenios internacionales y a contribuir a la incorporación del tema de la mujer en la agenda pública (37).

Los elementos contenidos en el primer Plan de Igualdad de oportunidades, se centraron principalmente en los ámbitos de legislación, familia, educación, cultura, trabajo, salud, participación y fortalecimiento institucional. Este primer plan contribuyó a la elaboración y ejecución de políticas de género de manera integral, a través de aumentar la conciencia sobre las desigualdades de género, así como a poner el tema no sólo en la agenda del gobierno sino también en la opinión pública. El Plan centra su discurso de ciudadanía sobre el concepto de igualdad de oportunidades, enfocado en la idea de la superación de desigualdades existentes entre hombres y mujeres, lo que garantizaría un acceso equitativo de éstas a los recursos y beneficios que le permitirán a las mujeres alcanzar la ciudadanía.

Los elementos que contienen el segundo plan de igualdad de oportunidades para mujeres y hombres, 2001 - 2010, se construye en un escenario en que se reconoce y legitima la necesidad de generar mejores condiciones para la equidad, recoge además la experiencia y evaluación del Plan anterior. La elaboración de este Plan apela a una construcción participativa a lo largo del país que permitió recoger las aspiraciones y demandas de diferentes sectores. Este pretende consolidar las políticas de género en la institucionalidad pública, promover la participación de las mujeres y promover el control ciudadano de las políticas (38).

El Plan se organiza en seis grandes temas: Una cultura de Igualdad, Promover los derechos de las mujeres y garantizar su pleno ejercicio, Participación en las estructuras de poder y en la adopción de decisiones, Autonomía económica de las mujeres y superación de la pobreza, Bienestar en la vida cotidiana y calidad de vida. Enfoque de género en las políticas públicas. Estos puntos se desagregan en objetivos y lineamientos con el fin de orientar las acciones concretas a desarrollar en el período, en los niveles más regionales y locales, que se traduzcan a través del diálogo y negociación con los diferentes actores, en concreciones específicas y atingentes a las realidades (39).

\section{Situación de los hombres y mujeres en Chile.}

A partir de los datos que arroja la encuesta Casen de 1998 (40), es posible identificar los principales aspectos que mide esta encuesta para describir la situación de las mujeres. La encuesta se refiere a las principales áreas salud, educación, trabajo, con el fin de, a partir de la situación comparativa respecto de los hombres, referirse a las condiciones de las mujeres. 
En términos generales se aprecia que la población femenina es levemente superior a los hombres, presentándose mayores diferencias en ciertos tramos de edad. La población que va entre los 0-18 años es la población que presenta una mayor proporción masculina. En cambio en el tramo de 60 años el 56,7\% corresponde a población femenina, indicando este dato que la población femenina vive más años. Este dato es relevante en cuanto obliga a mirar la situación de vejez de las mujeres, las condiciones socioeconómicas y de salud. Respecto a lo anterior cabe destacar que las mujeres habitan en mayor proporción que los hombres en los sectores urbanos. Siendo la Región Metropolitana la que concentra mayor proporción de mujeres que hombres, un $52,1 \%$.

De acuerdo a la proporción de población la jefatura de hogar femenina corresponde a un 22,8\% , y la jefatura masculina a un 77,2 \%. Siendo las regiones XII, V y Región Metropolitana las que presentan jefatura femenina por sobre la media. En cambio en los sectores rurales en las regiones donde la jefatura femenina se triplica corresponde a las regiones IV, VI, VII.

Respecto al ingreso, comparado hombres y mujeres, las mujeres reciben menores ingresos promedios de acuerdo a los quintiles de ingreso. La proporción de ingresos de los hogares liderados por hombres es 1, 5 veces el ingreso autónomo de las mujeres. La menor diferencia es percibida en los ingresos de quintiles más bajos, en cambio en los quintiles más altos, la diferencia es de 1,6 veces mayor el ingreso de los hombres. En otras palabras, mientras los hogares con jefes de hogar hombres en el quintil I, perciben ingresos autónomos $21 \%$ más altos que las jefas de hogar del mismo quintil; en cambio en el quintil $\mathrm{V}$, los hombres reciben ingresos que son superiores al de las mujeres en un 65,0\%. Es decir los hogares con jefatura femenina se encuentran en peores condiciones socioeconómicas para enfrentar la jefatura de hogar. En los hogares de quintiles más bajos y de jefatura femenina es posible observar que estos albergan en su interior un mayor cantidad de núcleos familiares que los de jefatura masculina.

Respecto a los indicadores de pobreza e indigencia, éstos dan cuenta de que proporcionalmente afecta mayormente a los hogares con jefatura femenina. La distribución de pobreza e indigencia es proporcional en el país, sin embargo las regiones en que la pobreza se concentra mayormente en las mujeres, en la regiones VII, VIII, IX, X, en estas regiones además se ubican los sectores rurales con mayor proporción de población en hogares pobres. Se destaca que la VIII, y IX regiones donde se concentra la mayor proporción de pobreza, así mismo una proporción mayor de población indígena.

La estrategia de superación de la pobreza en la década se ha concentrado en parte importante en la igualación de la escolaridad entre hombres y mujeres. Los datos respecto a educación señalan lo siguiente: si bien los indicadores de educación se aprecia son similares para hombres y mujeres, a fines de la década es posible apreciar una diferencia a favor de los hombres. Los datos indican que se aprecia mayores diferencias promedio de acuerdo a la residencia. La población urbana de las regiones logra escolaridad superior o promedio a la media nacional mayor que la población de sectores rurales. A partir de lo cual las regiones VII, VIII, IX, X, XI, tienen un porcentaje de escolaridad menor que el promedio nacional. La X región presenta el promedio de escolaridad más baja en hogares de jefatura femenina, de 6,3 años de estudio. En el caso de las jefaturas masculinas, el promedio más bajo se presenta en la VII región con 7,2 años.

De acuerdo a los antecedentes que señalan la población que no asiste a los establecimientos educacionales, la población entre 7-13 años, el 1,1\% no asiste. De la población entre los 14-17 años que no asiste es mayor correspondiendo a un $13,4 \%$ de hombres y al $12,6 \%$ de mujeres. Las razones de inasistencia para los hombres se relacionan con que están buscando trabajo, 0 
se encuentran trabajando esto es un 32,0\%, los que señalan no tener interés corresponde al 16 , $3 \%$ y aquellos que señalan dificultades económicas corresponde al 13,3\%. La Principal razón de inasistencia para las mujeres en el mismo tramo etáreo, corresponde a la maternidad o embarazo $21,2 \%$, a dificultades económicas $17,2 \%$, ayuda en la casa $16,9 \%$, no le interesa $13,3 \%$.

Respecto a salud la población adscrita al sistema público corresponde al $62 \%$, un $23,1 \%$ se encuentra adscrito al sistema privado, y el 10,9\% al sistema particular. De la población adscrita al sistema público un 64,2\% corresponde a población femenina mayor de 15 años y un 59,4\% a población masculina. La concentración de población femenina inscrita en el sistema público corresponde a los cuatro quintiles de ingreso. El 87,\% de las mujeres del quintil I, se encuentra adscrita al sistema público. En cambio las mujeres del quintil $\mathrm{V} ; 52,8 \%$ de las mujeres se encuentra adscrita en el sistema de ISAPRES.

La tasa general del país en torno a empleo en 1998, fue de 55,9\%. Los hombres alcanzaron participación laboral en un $74,6 \%$ en cambio las mujeres un $38,8 \%$. La mayor tasa de participación laboral se concentra entre los 30-44 años, un 72,8\% del total.

La relación existente, respecto a los ingresos que perciben hombres y mujeres, la encuesta señala que los hombres perciben un 40,6 \% más de ingreso que las mujeres. Esto varía de acuerdo al promedio de ingreso mensual de acuerdo al tramo de edad, los hombres entre 15-19 años tienen en promedio un salario mayor a las mujeres en un $12,3 \%$, esta cifra aumenta, en el tramo de 45-59 años ellos ganan un 59,9\% más que las mujeres, y el porcentaje aumenta a un $67,5 \%$ en el tramo de los 60 años.

En la medida que la relación edad/ educación aumenta la brecha salarial entre hombres y mujeres se incrementa. Aquellos ocupados que tienen entre 0-3 años de escolaridad, los hombres superan el ingreso de las mujeres en un 31,9\%, en aquellos de 13 o más años de estudio los hombres superan el ingreso de las mujeres en un $84,6 \%$.

\section{FONADIS. Fondo Nacional para la Discapacidad.}

A continuación desarrollaré algunos aspectos que permitan acercarse a la situación de las personas con discapacidad en Chile. Para ello será necesario dar cuenta del marco en que institucionalmente se ubica la problemática, para luego describir las principales características sociales, económicas, en las que se encuentra la población con discapacidad en nuestro país.

\section{Discapacidad en Chile. Fondo Nacional de la Discapacidad}

En el contexto de recuperación de espacios democráticos en el país, y como parte de la visibilización de problemáticas y nuevos actores sociales se incorpora en la agenda del país la elaboración de la ley que considera a las personas con discapacidad.

La política diseñada por los gobiernos de la concertación ha estado orientada sobre las ideas de contribuir al desarrollar una sociedad con equidad social, lo que se ha traducido en un esfuerzo por "implementar programas que apunten a crear condiciones de vida más equitativas en el proceso de satisfacción de necesidades del conjunto de la población. Ello exige la aplicación de una estrategia combinada de aplicación de políticas universales y de políticas selectivas (orientadas a sectores vulnerables). Las políticas han sido orientadas a través de tres 
líneas de integración las que permitirían superar las condiciones de desigualdad de la población estas son: programas de género, de edad, y de las diferencias (41).

En este contexto de nuevo enfoque de lo social de parte del estado es que, en 1994 se crea por mandato de la ley 19.284 de la Integración Social de las Personas con Discapacidad, el Fondo Nacional de la Discapacidad, entidad de carácter autónomo depende del Ministerio de Planificación y Cooperación. Ley que fue trabajada a través de la creación del Consejo Nacional de la Discapacidad (CONADIS), quienes fueron los encargados de formular la política Nacional sobre discapacidad, y de preparar un proyecto de ley que respondiera a los intereses de los sectores correspondientes.

La misión de esta institución ha sido definida como: "Contribuir a la integración social de las personas con discapacidad, mediante la administración eficiente de los recursos financieros que se ponen a su disposición" (42). La administración de los recursos estará orientada principalmente al financiamiento de programas de capacitación laboral, a la prevención y rehabilitación de las personas con discapacidad.

Los énfasis han estado ubicados principalmente en el sector salud, a través del cual se pretende la detección precoz de enfermedades, así como la rehabilitación de las personas con discapacidad, además de revisarse los sistemas de clasificación de la discapacidad.

Por otra parte en educación el acento ha sido puesto en la integración de las personas con discapacidad a la enseñanza regular, así como espacios de capacitación laboral.

En lo laboral se han apoyado espacios de incorporación laboral de las personas. Se ha promovido la contratación de personas con discapacidad, así como de capacitación laboral.

En los ámbitos de los espacios públicos se ha regulado el tema de la construcción y accesibilidad de las personas con discapacidad a los espacios públicos, así también en lo relativo a vivienda, subsidios y adaptaciones de las viviendas población con discapacidad.

Previo a este proceso de incorporación de la situación de las personas con discapacidad en nuestro país, predominó un enfoque asistencialista (el que respondía a las características del Estado, como entidad benefactora) respecto al tema de la discapacidad, lo que se vio reflejado en acciones sectorialistas y asistenciales preocupadas de la entrega de recursos o prestaciones médicas específicas. En este mismo sentido diversas entidades de carácter privado se ocupaban de la entrega de determinadas prestaciones, que con aporte del estado o no, permitiera atender a las necesidades de los grupos sociales a los que estaban dirigidas. Muchas de estas instituciones o instancias enmarcaron sus acciones a la obtención de recursos a través de colectas públicas.

\section{Situación de las mujeres y hombres con discapacidad en Chile}

No fue hasta 1996 que en Chile se incorpora oficialmente el tema de la discapacidad (43) en los registros de descripción poblacional. La encuesta Casen correspondiente a ese año, permitió la actualización del diagnóstico de la situación económica de los habitantes del país, considerando los sectores urbano y rurales. Los datos recogidos permitieron un acercamiento a los procesos de definición, cuantificación y por sobretodo de visibilización de la problemática de las personas con discapacidad. Cabe señalar que la encuesta que es aplicada cada dos años, no contempla, en su versión posterior, el tema de la discapacidad. Los antecedentes y estudios posteriores recurren a los datos de la encuesta, se realizan descripciones sobre la base de este único 
registro. Como parte de las líneas de trabajo de FONADIS ha sido desarrollar investigaciones hacia la comprensión y conocimiento sobre las condiciones sociales y económicas en las que se encuentra la población con discapacidad.

En Chile existen, de acuerdo a los antecedentes de la encuesta Casen 616.434 personas con algún tipo de discapacidad, lo que corresponde a un $4,3 \%$ de la población total del país. Los porcentajes de población se concentran principalmente en las regiones VII, IX y XI. De acuerdo a las características de edad, la población que presenta discapacidades es la población mayor de 60 años.

Las discapacidades más recurrentes en la población son: en un 27,3\% discapacidades para oír, principalmente en población adulta. Discapacidad para ver de un 26,9\% y discapacidades físicas de un $21,2 \%$. Los porcentajes disminuyen son relación a la discapacidad mental 13,1\%, discapacidad por causa psiquiátrica 5,9\% y discapacidad para hablar 5, 6\%.

La distribución de la población con discapacidad es homogénea, 49,6\% de los hombres presentan alguna discapacidad, un $50,4 \%$ de las mujeres presenta algún tipo de discapacidad.

Con respecto a la distribución de la discapacidad de acuerdo a la edad, el 15,5\% corresponde a menores de 14 años, entre los 15 y 29 años, la población con discapacidad corresponde a un 16,3\%. La población con discapacidad entre los 30 y los 60 años es de 35,3\%, y mayores de 60 años es de 32,9\%; antecedentes que permiten afirmar que la relación entre aumento de edad y aparición de discapacidad es positiva.

En relación a la edad y el tipo de discapacidad es posible señalar que la presencia de discapacidades de carácter físico y psiquiátrico se concentra entre los 30 y 60 años, la discapacidad para hablar se concentra entre los 0 y 14 años, y la discapacidad para ver se concentra en población mayor de 60 años.

Los datos aportados por la Casen nos indican que la educación recibida por las personas que presentan una discapacidad es menor $22,4 \%$ en comparación al porcentaje de la población sin discapacidad (37,0\%). A esta relación se acompaña; el que las familias que presentan ingresos elevados, alcanzan mejores niveles de educación. La cifra de analfabetismo, para el caso de las personas con discapacidad $23,3 \%$ es mayor que el del porcentaje de la población en general, 4 , $9 \%$.

Respecto a la ocupación encontramos que la población mayor de 14 años (en edad de trabajar) de un total de $84,5 \%$ de la población, el 25,9\% estaban, al momento de realizarse la encuesta, desarrollando una actividad laboral, el $2 \%$ se encontraba desocupados y un $72,1 \%$ se encontraban inactivo.

La población con discapacidad en un 77, 6\% recibe atención de salud en el sistema público, sólo un $9,2 \%$ se atiende en el sistema privado.

De acuerdo al análisis de los datos de la encuesta Casen desarrollada por el estudio para FONADIS, quisiera destacar lo siguiente:

Las mujeres con discapacidad reciben menor atención dental o médica en el sistema escolar, en comparación a la población masculina con discapacidad. 
Algo similar ocurre con respecto a la población femenina que concurre al sistema escolar es menor, tanto en el caso de la población con discapacidad como de la población sin discapacidad.

Tanto mujeres con o sin discapacidad cotizan en menor cantidad que los hombres en condiciones similares. Una relación semejante se produce en el trabajo remunerado, los hombres tienden a realizar trabajos por cuenta propia.

Los datos de este estudio destacan que, el nivel u oficio de las personas con discapacidad es menor si se compara con población sin discapacidad, ahora bien la tendencia es que los hombres con discapacidad tienden a realizar oficios o actividades que podrían ser catalogadas como actividades de carácter femenina.

En la población con y sin discapacidad las mujeres viven menos en pareja que los hombres; algo similar ocurre con respecto a la pertenencia al hogar principal, las mujeres más que los hombres pertenecen al hogar principal.

\section{DESCRIPCIÓN DEL PROCESO DE RECOLECCIÓN DE DATOS.}

El Estado a través de MIDEPLAN se acerca a las problemáticas sociales, en la década de los noventa, por medio de la definición de diferentes estructuras que abordan problemáticas asociadas a sujetos específicos. Cada una de estas estructuras contienen historias, estructuras, sujetos a los que orienta sus acciones, lineamientos, diferente modos en que las problemáticas han sido abordadas.

Para la recolección de los datos del estudio se desarrollaron una serie de procesos diferentes de acuerdo a las características de la estructura que se observó. A continuación detallo el modo en que se definió a recolección de antecedentes.

\section{Constitución del corpus documental}

1. Selección de los documentos de análisis.

En primer término las fuentes primarias la constituyeron materiales o documentos que recogieran por una parte los discursos oficiales de la institución y que al mismo tiempo se encuentran disponibles o abiertos a la opinión pública. Por otra, un elemento que también primó en la elección de los materiales o documentos fue, que estos no sólo pudieran recoger los discursos u opiniones en torno a temáticas específicas, sino también que recogieran imágenes o fotografías.

En torno a la temática de las personas con discapacidad un elemento importante lo constituyen los registros de la revista de publicación periódica editada por el Fondo Nacional de la Discapacidad, con el fin de sensibilizar, informar, comunicar las acciones y procesos no sólo institucionales sino también los procesos personales y sociales del mundo de la discapacidad.

El material de trabajo en este nivel, con respecto a las personas con discapacidad, se centró fundamentalmente en la revisión de la revista de edición periódica "Atrévete" de tiraje cuatrimestral al 2001. 
Para ello se recogió material en el FONADIS, revistas del año 1997 a la fecha. Parte importante del material también fue obtenido de otras instituciones que reciben periódicamente la publicación de ésta y que contaban son otros números anteriores.

Otro material revisado lo constituyeron los materiales de apoyo fundamentales definidos por el equipo de trabajo, éste dice relación con las Normas Uniformes, con el material elaborado por encuentros internacionales relativos a al temática laboral y discapacidad. Se revisaron las bases de concursos a Fondos Concursables convocados por FONADIS desde 1997 a 2000.

En torno a la temática de la Discapacidad y de las personas con discapacidad se revisó el material elaborado por MIDEPLAN, que recoge el trabajo desarrollado en 1999, a través del Grupo de trabajo interministerial.

En el tema de las mujeres, el registro que surge como contenedor de las imágenes y concepciones acerca de las mujeres, lo constituyen los discursos elaborados por las encargadas del Servicio al iniciar el período en su calidad de Ministra. Además se buscaron materiales discursivos que recogieran y posicionaran en la opinión pública la temática de las mujeres. Es decir se recurrió a los discursos de las encargadas, tanto en los procesos de constitución del Sernam así como en los procesos de la década de los noventa, además se revisó material discursivo elaborado por los Presidentes de la República del período, con ocasión de celebraciones de carácter nacional, en donde estuviese contenido el tema de las mujeres y de género.

Parte del material revisado lo constituyen las publicaciones que recogen la historia de conformación e instalación de la temática de género y de las mujeres. Documentos que a modo de registros histórico recogen el proceso de instalación de la temática, los modos de instalación discursiva, así como las reflexiones y los elementos que se destacan en un inicio.

Por otra parte se revisaron los registro que orientan el trabajo y políticas con respecto a las mujeres y género. Para ello se revisaron materiales conductores, materiales ejes que definen los énfasis y estrategias de acción: Planes de igualdad de oportunidades.

\section{Procedimientos metodológicos para la recolección de información}

\section{Elaboración de una ficha}

Material gráfico elaborado por FONADIS:

Para el análisis del material gráfico revisado se procedió en una primera instancia a observar el material de modo de seleccionar dos publicaciones por año de publicación.

La publicación de la revista se inicia con un tiraje mensual desde el año 1995, situación que cambia en el año 2000, la publicación es cuatrimestral.

La ficha de trabajo permite observar las publicaciones de modo de establecer, por una parte un parámetro que permita comparar de igual manera las características de las publicaciones.

La tabla recoge:

- La portada, que recoge en forma descriptiva las características de diseño y diagramación de la portada, los elementos que destacan en ella, los contenidos que se definen como 
relevantes en ella, el modo de presentar los contenidos. En esta parte se describen las imágenes gráficas de portada utilizadas en la confección de las revistas.

- El año y fecha de publicación.

- Contenidos: que destaca por una parte los contenidos de la publicación, más bien referidos a información y noticias y por otra parte destaca aquellos contenidos que aparecen más bien como críticas, reflexiones o comentarios que contienen en sus desarrollo un acercamientos más activo en lo discursivo.

- Editorial: en esta sección se pretende revisar con mayor acuciosidad la editorial de cada una de las publicaciones es decir, se recoge el titulo con que se presenta la editorial, el responsable de éste, principalmente la persona encargada de la dirección de el FONADIS. Se detallan los contenidos y conceptos utilizados por la persona encargada de la elaboración de la editorial.

- Títulos y palabras claves. Bajo esta sección se recogen los títulos de los artículos y palabras claves contenidas en los artículos.

El registro permitió observar y comparar la evolución de los conceptos, las palabras claves y su asociación, así como las imágenes que tienden a vincularse a determinados contenidos. Los modos en que se presentan los contendidos y conceptos que se instalan a través de la publicación.

\section{Selección de los equipos}

Cada una de las estructuras: Ministerio de Planificación y Cooperación (MIDEPLAN), Fondo Nacional para la discapacidad (FONADIS), Servicio Nacional de la Mujer (SERNAM), presentan modos diferentes de estructurar los departamentos o secciones de trabajo.

Cabe destacar que al momento de establecer el contacto con el equipo de Sernam el 2000, este equipo contaba con una estructura diferente a la presentada al momento de la entrevista 2001, lo que se tradujo en nuevos contactos y entrevistas debido al proceso de reestructuración de la institución.

Para la selección de los equipos y personas claves a entrevistar se procedió a revisar la estructura organizacional de modo de determinar en ella el equipo encargado de la elaboración y desarrollo de lineamientos u orientaciones políticas en torno a las temáticas de las mujeres y personas con discapacidad. En la estructura de MIDEPLAN, se procedió a revisar la estructura de modo de definir los equipos o personas contraparte de las estructuras de FONADIS y Sernam en las temáticas específicas y su aporte en la elaboración de políticas sociales. Luego de definir la estructura se procedió a entrevistar a cada uno de los encargados de los departamentos seleccionados, para luego entrevistar a los equipos de trabajo.

Durante el proceso de acercamiento y entrevistas a los equipos se determinó como importante el contactar a los equipos encargados del tema comunicacional y de relaciones de las estructuras de FONADIS y SERNAM. Los equipos de cada una de las instancias entrevistadas en las estructuras señalaron como de vital importancia, los departamentos encargados del tema de las comunicaciones y relaciones, debido a que éstos por un lado han estado presentes en los procesos de instalación de las temáticas, así como también manejan la relación con los otros, el entorno, y contienen la responsabilidad de instalar y posicionar las temáticas en la opinión pública y en las estructuras estatales. 


\section{Entrevista}

Para el desarrollo del trabajo de indagación en torno a las representaciones de mujeres y personas con discapacidad, los procesos a través de los cuales las estructuras dan cuenta de los procesos así como de los elementos que dicen relación con la inclusión y exclusión de las mujeres y personas con discapacidad, se elaboró una entrevista semiestructurada que pudiera orientar la recolección de información.

A través de la aplicación de la entrevista semiestructurada, fue posible recoger desde los y las encargadas y los equipos, los elementos que para cada uno de ellos están contenidos y relacionados con los sujetos mujeres y personas con discapacidad. Cabe destacar en este nivel que las entrevistas realizadas en la estructura de Sernam sólo recoge la percepción de los equipos en torno a la temática de las mujeres, en cambio en la estructura de FONADIS la entrevista se orientó sólo al tema de las personas con discapacidad.

La aplicación del instrumento se desarrolló en forma libre acomodando las preguntas de modo de incorporar éstas en el proceso de ordenamiento y presentación de los discursos de cada una de las personas.

La entrevista por lo general tuvo una duración de 45 minutos a una hora, tanto en los espacios individuales con los y las encargadas así como con los equipos. Estas se desarrollaron en los espacios laborales, salas de reuniones o lugares escogidos por las propias personas o equipos para la realización de la entrevista. Se realizó un total de 10 entrevistas, las que fieron transcritas y pre - analizadas.

Cabe destacar que las personas en sus procesos discursivos, no separaban sus opiniones como personas públicas y privadas, es decir se referían en sus opiniones a las percepciones construidas en los procesos de acercamiento al tema de las mujeres y personas con discapacidad, no sólo en el ámbito laboral sino también social y personal.

\section{ANALISIS DE LA INFORMACION}

El análisis de la información permitirá referirse a los procesos a través de los cuales, los y las hacedores de políticas públicas, de los establecimientos o servicios indicados como casos; construyen representaciones de los sujetos, mujeres y personas con discapacidad, que definen como foco de sus intervenciones.

El estudio se ha propuesto el dar cuenta de los sujetos que han construido las estructuras estatales surgidas en la década de los noventa en Chile a través de sus políticas sociales. Por medio de un acercamiento de carácter exploratorio se presentarán a continuación las representaciones a través de las cuales las estructuras estatales dan cuenta de los sujetos hacia los que orientan sus políticas sociales (qué sujetos), se describirán los elementos a través de los cuales las estructuras estatales resignifican a los sujetos emergentes (cómo) y finalmente los elementos de inclusión/ exclusión que utilizan las estructuras estatales y las políticas sociales en los procesos y representaciones de sujetos emergentes (por qué).

Para el desarrollo de la investigación, como he señalado se han revisado material escrito, discursos públicos, así como el discurso de las personas que están involucradas, a través su trabajo en la estructura estatal, en el diseño, evaluación, difusión tanto de políticas sociales como de orientaciones metodológicas, evaluativas, énfasis temáticos. 
La aproximación, tanto a los materiales, como a las y los hacedores de políticas sociales; acercamiento de segundo orden, permite observar las distinciones de las personas que realizan políticas sociales, estas comunicaciones escritas, gráficas, y discursivas, reflejan los procesos representacionales de las políticas sociales. Es importante resaltar que la observación realizada es sobre la observación de los y las hacedoras de políticas sociales, no se observa a los sujetos, ni a las estructuras, sino son observaciones de las observaciones de los hacedores de políticas sociales, el Estado.

Los casos observados, perteneciente a la estructura dependiente del MIDEPLAN, ha sido el FONADIS y SERNAM. Para dar cuenta de los datos y antecedentes, me permitiré dividir la información obtenida en cada una de las estructuras de modo de establecer procesos particulares, que sin el afán de comparar podrán dar cuenta de aspectos particulares y que podrán indicar determinadas similitudes o diferencias entre cada una de las estructuras. Es importante distinguir que los resultados serán analizados separadamente considerando que existen diferencias que podrían ser recogidas en los procesos pero que no pretenden más que ordenar la información y no compararla.

\section{Análisis SERNAM}

A continuación me permito presentar el análisis de la información recogida en la estructura del Servicio Nacional de la Mujer, SERNAM. Para ello me referiré a los principales hallazgos los que serán graficados en una tabla resumen, luego de la cual se sintetizan los puntos principales para luego desarrollar cada uno de manera de profundizar en los aspectos relevantes.

De acuerdo a lo señalado en el capítulo, la información ha sido analizada separadamente con el objeto de dar cuenta de los elementos que están presentes en cada una de las instituciones, a partir de lo cual será posible indicar las particularidades de ellas. Es importante destacar una vez más que la separación de la información responde más bien a la posibilidad de detallar las especificidades, sin tener con ello la intención de comparar los datos.

La información ha sido recogida a través de entrevistas realizadas a los equipos que generan políticas orientadas a las mujeres; a la comunicación de los programas así como también a la revisión y análisis de los principales materiales y discursos generados por estos durante la década del noventa.

El análisis de la información dará cuenta de los sujetos que han construido las estructuras estatales surgidas en la década de los noventa en Chile a través de sus políticas sociales. El acercamiento como he señalado, es de carácter exploratorio, para ello se presentará a continuación las representaciones de mujeres a través de las cuales las estructuras estatales dan cuenta de los sujetos hacia los que orientan sus políticas sociales (qué sujetos); se describirán los elementos a través de los cuales las estructuras estatales resignifican los sujetos emergentes (cómo) y finalmente los mecanismos de inclusión/ exclusión que utilizan las estructuras estatales y las políticas sociales en los procesos y representaciones de sujetos emergentes (por qué).

(i) Representaciones a través de las cuales las estructuras estatales dan cuenta de los sujetos hacia los que orientan sus políticas sociales. (qué sujetos)

\section{Tabla resumen:}




\begin{tabular}{|c|c|c|}
\hline REPRESENTACIÓN & ANTES DE LOS NOVENTA & $\begin{array}{l}\text { DECADA DE LOS } \\
\text { NOVENTA }\end{array}$ \\
\hline $\begin{array}{l}\text { Desde el Estado, la política } \\
\text { social }\end{array}$ & $\begin{array}{l}\text { Política del bulto } \\
\text { No se toleran diferencias. Se } \\
\text { busca homogeneizar } \\
\text { Carencia } \\
\text { Marginalidad }\end{array}$ & $\begin{array}{l}\text { Emergen temas } \\
\text { Focalización } \\
\text { Reconocimiento de la } \\
\text { diversidad, heterogeneidad } \\
\text { Potencialidad } \\
\text { Vulnerabilidad }\end{array}$ \\
\hline $\begin{array}{l}\text { El entorno - lo social y } \\
\text { cultural }\end{array}$ & $\begin{array}{l}\text { Invisibilidad } \\
\text { ( no es sujeto social) } \\
\text { Temas ocultos } \\
\text { Lo privado } \\
\text { Insensibilidad (no se habla, } \\
\text { no se dice) }\end{array}$ & $\begin{array}{l}\text { Visibilidad } \\
\text { Reconocimiento sujeto social } \\
\text { Emergen temas } \\
\text { Lo público } \\
\text { Sensibilidad (se habla, se } \\
\text { dice, se ponen los temas) }\end{array}$ \\
\hline $\begin{array}{l}\text { Caracterización de los } \\
\text { sujetos mujeres desde los y } \\
\text { las hacedoras de políticas } \\
\text { sociales }\end{array}$ & $\begin{array}{l}\text { No conocen. No tiene } \\
\text { conciencia. Desconoce } \\
\text { No sabe } \\
\text { Participación subsumida en } \\
\text { demandas globales } \\
\text { Condiciones sociales, } \\
\text { económicas, culturales } \\
\text { ligadas a la pobreza } \\
\text { Debe obediencia al marido } \\
\text { Dependencia } \\
\text { No tiene derechos }\end{array}$ & $\begin{array}{l}\text { Mujeres se han hecho } \\
\text { conscientes } \\
\text { Mujeres saben } \\
\text { Genera opinión pública } \\
\text { Participa, exige derechos } \\
\text { Diversidad de condiciones } \\
\text { sociales, culturales y } \\
\text { económicas } \\
\text { No debe obediencia al } \\
\text { marido } \\
\text { Mayor autonomía } \\
\text { Se reconocen sus derechos }\end{array}$ \\
\hline
\end{tabular}

Respecto al sujeto mujeres en Chile, me referiré a los elementos que distinguen los y las hacedoras de políticas sociales orientadas a las mujeres, es decir las representaciones de mujeres que genera la estructura estatal. En un primer momento quisiera destacar que la situación política del país antes de los comienzos de la década marca un cambio importante respecto de las representaciones de las mujeres tanto desde el Estado como desde la sociedad en su conjunto. Antes de la década de los noventa, las políticas públicas estaban orientadas a un agregado de sujetos sobre los cuales no cabían distinciones de género, etnia, edad, etc. Posteriormente las políticas se orientaron sobre la idea de focalizar, para lo cual era necesario identificar determinadas características que establecieran diferencias significativas y que permitieran desde allí elaborar estrategias específicas de modo de hacerlas más oportunas y eficientes. Hoy se identifican las diferencias en el sentido de no sólo apuntar a las carencias sino también recoger las fortalezas de los grupos y sus características.

Asociadas a las representaciones de mujeres desde el Estado, son las distinciones respecto del entorno, de lo social y cultural. Me permito hacer una división entre las distinciones de antes y durante la década de los noventa, reconociendo en este ejercicio la posibilidad de simplemente, concentrar en la década determinadas características, lo que no significa que las representaciones sean exclusivas, ni se encuentren presentes sólo durante ese período. Quisiera destacar principalmente que los temas ligados a las mujeres antes de los noventa aparecen como temas de carácter privado, desde donde la situación cultural, social, política, económica de las mujeres parece invisibilizado y al albergue de otro, de quien se supone y atribuye una dependencia. Tendencia que cambiará, en la medida que las temáticas ligadas a 
las mujeres, son revestidas de un carácter público. En otras palabras, no sólo se hacen visibles como sujetos sino también se visibilizan las problemáticas, las situaciones sociales y culturales asociadas a esta invisibilidad. Las mujeres son identificadas como sujeto desde ellas y no en subordinación a una identidad que les es ajena o de dependencia (de y para otro).

Estas representaciones son coincidentes con las descripciones o caracterizaciones que los y las hacedoras de políticas sociales realizan respecto de las mujeres. En la década de los ochenta las mujeres en tanto representaciones aparecen como dependientes de otros en su situación social y económica, las mujeres deben obediencia a los maridos, las mujeres se encuentran como otros en situación de pobreza, sus derechos son asociados o encubiertos, subsumidas en las demandas de otros. Ya en la década de los noventa esta situación se transforma, emerge la idea de que existiría mayor conciencia de su condición de mujer, sus derechos. A su vez la representación de ellas surge desde una mayor autonomía, con derechos y donde la obediencia civil, al marido es rota, lo que le permite constituirse en si misma como sujeto, con características propias.

A continuación desarrollaré los elementos destacados anteriormente, profundizaré en los aspectos que resaltan los hacedores de políticas sociales respecto de los sujetos, mujeres; es decir daré cuenta de las observaciones de las observaciones que realizan éstos.

\section{Representaciones de las mujeres desde el Estado y las Políticas Sociales.}

Cabe destacar que a partir de las entrevistas y del material recogido es posible establecer esta división aparente en el proceso de elaboración de representaciones enmarcado en un momento histórico determinado por la democracia y antes de ésta.

Para los y las hacedoras de políticas sociales, en los años ochenta la política social, es definida como la política del bulto. Es decir, a través de la intervención, se homogeneiza la problemática social y con ello a los sujetos en que se pretende concentrar és ta. Las diferencias no son toleradas ni asumidas por el Estado, no se trabaja sobre ellas. Esta situación, el desconocimiento de las particularidades de las diferencias, acrecienta la marginalidad, existen sectores que quedan fuera, que no son alcanzados por las políticas generales. La homogeneización de la problemática impide establecer distinciones que orienten las acciones y recursos diferenciadamente, "...si tú piensas en las políticas sociales de antes eran políticas sociales que eran para el bulto, digamos, o sea casa pa' todos, salud pa' todos, vacuna pa' todos, educación pa' todos".

Es decir el Estado no construye distinciones respecto de las personas a alas que dirige sus acciones. Con ello las mujeres son incorporadas sin diferencias a las distinciones que se elaboran respecto de la pobreza y de la población hacia la que se dirigen las políticas sociales.

En los años noventa se identifica un quiebre, marcado principalmente por la emergencia de los sujetos. La política social es definida a partir de las diferencias, las mujeres en este período emergen como sujetos de política social. El Estado se abre, abre las distinciones que permiten un acercamiento diferenciado a los sujetos de acuerdo a categorías de edad, sexo, diferencias (discapacidad - indígena), "entonces empieza a surgir la diversidad: que la educación tiene matices respecto de las mujeres, cuándo tienen las mujeres problemas o los pobres".

Desde las distinciones elaboradas e identificadas a través del material recogido, es en los noventa que surge la diversidad, es decir se produce el conocimiento de las diferencias existentes entre sujetos sociales. Es decir, el reconocimiento de que no existe un solo tipo de 
mujer sino las mujeres, presentan sus características particulares, ellas mismas requieren ser diferenciadas, particularizadas, "yo creo que hay varias, yo creo que no hay una sola mujer. Porque realmente que la situación económica, el grupo etáreo, todo eso marca grandes diferencias, yo creo que no es la mujer, yo creo que son las mujeres en situaciones distintas". Desde el discurso es posible afirmar que las distinciones se centran en que sobre el reconocimiento de un sujeto mujer, se suma la identificación de aspectos que determinan la diversidad y multiplicidad de estas mujeres. Estos aspectos se refieren principalmente a elementos relacionados con el acceso a educación, trabajo, condiciones de pobreza. Además se identifica la necesidad de establecer en los "mismos grupos" las diferencias que pudieran ser determinantes, por ejemplo: identificar las diferencias, en cada uno de los quintiles, identificar las necesidades y la situación de las mujeres, se habla de las brechas existentes, tanto entre las mujeres que presentan o comparten determinadas características y entre ellas y los hombres en situación similar.

Esta apertura establece la necesidad de instalar formalmente mecanismos que permitan profundizar en las condiciones y caracterización de las mujeres, para ello se plantean investigaciones, se socializan experiencias de trabajo desarrolladas tanto por las ONG, Centros de investigación, académicos, etc., es decir discusiones que posicionan, resitúan y también permiten reconstruir nuevas representaciones de mujeres.

Es decir el proceso está marcado por la necesidad de conocer, e identificar al otro en sus diferencias para desde allí construir estrategias de intervención acorde a las realidades que se identifican como diferentes.

Se produce un cambio de conceptualizaciones desde el Estado, el concepto de marginalidad es cambiado por el de vulnerabilidad, a lo que se suma la posibilidad de operar desde las políticas sociales sobre realidades y necesidades específicas y diferenciadas. Ahora bien, resulta interesante detenerse en el concepto de vulnerabilidad asociado a las mujeres durante la década de los noventa. En este concepto está contenida la idea de que puede ser lesionado, que puede ser herido, representa la condición de indefensión de las personas a las que se orienta la política social en un inicio de los noventa. En otras palabras se referido a sujetos sin derechos, en condiciones de alto riesgo y baja protección, es desde donde se reconstruye este concepto mujeres.

El Plan de Igualdad de Oportunidades para las mujeres 1994-1999 como instrumento socializador y orientador no sólo de la política orientada a las mujeres sino también de las representaciones contenidas en éste, da cuenta de este proceso de diferenciación, a inicios de los noventa, de la sociedad a través del reconocimiento de las mujeres, "se ha formulado una Política de lgualdad de Oportunidades destinada a generar los espacios y posibilidades de desarrollo de todas las personas, otorgando un reconocimiento a la igualdad de oportunidades y derechos a hombres y mujeres" (44), desde esta afirmación es posible destacar que se produce un reconocimiento de otro y que a su vez este sujeto se iguala social y simbólicamente en cuanto le son reconocidos sus derechos.

Este Plan recoge la caracterización de la situación de las mujeres de acuerdo a criterios de vulnerabilidad en los que fueron centradas las políticas sociales de inicio de los noventa. El documento da cuenta de las mujeres en relación a diversos ámbitos y su relación con las instituciones.

El documento establece estas relaciones refiriéndose principalmente a los cambios constitucionales y jurídicos, de modo de resguardar los derechos de las mujeres; respecto de la 
familia, en torno al resguardo de los derechos y oportunidades para mujeres y hombres considerando las diversidades de familias, respecto a la educación se reconoce un importante impacto no sólo en el refuerzo de imágenes/ estereotipos y roles a través de los programas y textos escolares sino también en los modos de establecer las relaciones entre profesores/ as y alumnos/ as; respecto al trabajo, la situación de salud de las mujeres; acceso y participación social y política de las mujeres. Un aspecto importante que se destaca en el documento es la necesidad de instalar y fortalecer la institucionalidad pública en la evaluación de políticas de igualdad de oportunidades.

\section{Representaciones de las mujeres desde el entorno: social y cultural.}

Para las hacedoras de políticas sociales las representaciones de las mujeres respecto al entorno social y cultural, se construye en un constante proceso de cambio, las mujeres son representadas respecto a otro, ocultadas a la visibilidad y el reconocimiento como sujetos sociales. Cabe destacar que para efectos de graficar las representaciones serán situadas respecto a un tiempo determinado sin que esto necesariamente signifique que las representaciones sean exclusivas de un momento histórico determinado y por tanto pueden darse simultáneamente.

Antes de la década de los noventa, de acuerdo al análisis del material obtenido, las mujeres son distinguidas respeto a b privado, dependiente. Es desde esta construcción que los temas sociales, económicos, culturales que les afectan se explican y abordan desde otro. Las mujeres son asociadas al mundo privado de la familia, la casa, el hogar. Principalmente a los roles de cuidado, afecto, reproducción.

A partir de esta representación, la discriminación de las mujeres aparece como normalizada, tanto desde las mujeres como desde el entorno.

Es posible interpretar que la invisibilidad está asociada a la imposibilidad no sólo de ser/ hacer, sino también de conocer, de tener/ obtener conocimiento respecto a si misma y a otros. Desde allí las mujeres, no pueden sentir, pensar, decidir, querer, en la medida que no conocen, no se re - conocen desde el ser y el hacer. La invisibilidad, normaliza el desconocimiento. Estas representaciones están asociadas a la concepción que las mujeres no se encuentran capacitadas de decidir sobre ellas mismas.

El tema de la insensibilidad es planteado por las entrevistadas, respecto a la percepción del entorno respecto de las mujeres, "...en el principio yo creo que uno de los grandes temas fue el tema de la insensibilidad", es decir, el entorno ha perdido el sentido, no es capaz de percibir, de sentir. La dificultad para construir representaciones estaría instalada en la dificultad para percibir al otro.

Las hacedoras de políticas sociales señalan, reconocen en el entorno la dificultad para producir aperturas que permitan el reconocimiento de las mujeres, lo que favorece la normalización de la negación y circunscribir a ésta a lo privado.

Como contraparte en la década de los noventa, las mujeres, son visibilizadas, reconocidas en su carácter de sujeto social.

Para las entrevistadas esta visibilización, la posibilidad de ser vistas, aparece referida desde dos distinciones, desde las distinciones que las propias mujeres harían de sí mismas y aquellas que el entorno haría respecto de ellas, "se han ido visibilizando, o sea se han hecho 
patentes, porque las mujeres se han hecho más conscientes de cuáles son sus derechos".

La ruptura, marca un limite relacional, se produce una relación entorno sujeto. El reconocimiento de las particularidades, problemáticas, derechos, la emergencia de la mujer como sujeto social, y público. Se le visibiliza como sujeto respecto a un entorno y el entorno establece distinciones que regulan la incorporación de ésta en el mundo social.

Desde las distinciones realizadas por las entrevistadas, estas señalan que son las mismas mujeres las que a partir de un proceso de organización y demanda social ponen el tema,“...la mujer primero necesitaba ser reconocida como un sujeto social, pero esto siempre hablando como una elite que apoyaba y presionaba", sin embargo la presión social ejercida para que esto se produjera, provenía de un grupo que presenta un discurso y un proceso consciente de demanda y que asume la presión social en nombre de las mujeres, es decir este proceso de visibilización de reconocimiento de ser y hacerse consciente es un proceso gradual en el que algunas, aquellas que acceden a otras distinciones son capaces de identificar y de movilizarse.

Se reconoce un cambio de posición de la temática en el mundo público, "lo que hasta ayer estaba silenciado en la intimidad de millones de mujeres, aquello que parecía ocupar la sección de variedad de los medios de comunicación, 0 el apéndice concedido graciosamente en agendas y programas, es hoy un tema crucial que se instaló en el pensamiento y en la acción del mundo contemporáneo." Se rompe el silencio, lo que aparece resguardado por la intimidad, por lo privado e invisible, la transformación no es sólo discursiva, sino también pública, en la transformación de las acciones, los modos de representar la temática.

Al mismo tiempo en esta afirmación está contenida la idea de que las mujeres son asociadas y construidas en una imagen de mujeres que sólo ocupan espacios marginales o anexos a temáticas de mayor importancia. La temática en si misma no parecía sostenerse en si misma con independencia de otros temas.

La representación que las hacedoras de políticas sociales respecto al entorno señalan que la construcción de distinciones se sitúa en el proceso de reconocimiento de las mujeres como sujetos sociales, desde la comprensión, reconocimiento y valoración de los aportes de estas no sólo en lo privado sino también en lo público. Este reconocimiento se sitúa en el Estado en la medida que se produce una representación de las mujeres desnormalizando la invisibilidad y discriminación, es decir sobre la base de que "la mujer se constituyera más en un sujeto social y pudiera hacer aportes en la vida pública, así como había hecho durante toda la historia mucho más en lo privado, como aportar en lo público". Sin embargo cabe señalar que el discurso de transformación de las representaciones de mujeres, parecen retornar al mundo social para legitimar e instalar transversalmente estas nuevas representaciones de mujeres.

En este sentido, se señala que las mujeres se han hecho más conscientes de sus derechos. Con ello cambia la relación del entorno, lo modos de mirar y establecer juicios respecto a los actos o vivencias de éstas, el tema del acoso sexual y de la violencia de que son objeto resultan ser ejemplos relevantes del cambio en las distinciones realizadas no solo por los otros m mujeres sino también por las mismas mujeres, quienes deben incorporar una nueva representación de si mismas. 
En este punto cabe señalar que las distinciones de las hacedoras de políticas sociales indican que las representaciones de mujeres, la idea de visibilización de éstas aparece estrechamente ligada a la idea de "hacerse" y de "conciencia", es decir como un proceso que esta situado en las comunicaciones entorno - mujeres y en las propias distinciones que las mujeres elaboran sobre sí mismas. El conocerse y ser reconocidas será un proceso que parece ser potenciado por las intervenciones sociales.

Es a partir de los cambios en las representaciones de normalidad, respecto a los derechos de las mujeres; que las mujeres reposicionan sus propias distinciones sobre sí mismas y por tanto estructuran un reconocimiento público de esta nueva representación de mujeres. Ejemplo de ello es la implementación de la ley de violencia intrafamiliar, que para las hacedoras de políticas sociales establece un límite entre las distinciones de antes (mujeres invisibilizadas, negadas, dependientes, incapaces, etc) y después de los noventa "las mujeres comienzan a acudir masivamente y empiezan a darse cuenta que no es normal que les ocurra eso..." esta afirmación da cuenta de el impacto social del cambio en las representaciones de las mujeres.

El desarrollo de campañas de sensibilización, de puesta pública de nuevas representaciones ligadas a los derechos, genera aperturas, éstas permiten al sistema abrirse al otro, al reconocimiento de necesidades y presencia del otro. El otro permite ser visto, reconocido.

Desde el discurso de las hacedoras se puede afirmar que estas reconocen un proceso dinámico de construcción de representaciones. La apertura del entorno permite poner en la agenda pública, en la discusión los temas relativos a las mujeres. Desde esta apertura los programas cambian su foco de atención, las políticas sociales son dirigidas, en un inicio de los noventa a grupos vulnerables. Las aperturas producidas en un inicio sitúan como ya he señalado, a las mujeres respecto a su condición de vulnerabilidad. En este marco se habló de la superación de la pobreza, estos temas se incorporan en la agenda de gobierno, en el entendido de disminuir las brechas de género y de pobreza de la población, esto queda reflejado en la estructuración del Plan de lgualdad de Oportunidades 1994-1999, parte importante de la definición de estrategias y medidas tendientes al cambio comunicacional, institucional, así como legislativo y judicial está contenido en el documento, que centra su foco en las mujeres en condiciones de vulnerabilidad y además centra su atención en estrategias de cambio en los ámbitos educativo, laboral, familiar de salud.

\section{Representaciones de las mujeres: Caracterización de los sujetos mujeres desde los y las hacedoras de políticas sociales.}

A continuación profundizaré, desde los materiales recopilados y desde el habla de las hacedoras de políticas sociales las representaciones de mujeres elaborados por ellas. Resulta de importancia destacar que las distinciones que serán referidas, contienen en si mismas las representaciones que ellas mismas distinguieron provenir de parte del Estado y del entorno y las cuales fueron identificadas anteriormente enfatizando procesos de acuerdo al momento histórico en el que se sitúan.

Los aspectos que los y las hacedoras de políticas sociales destacan respecto a las mujeres, que antes de la década de los noventa, las mujeres son identificadas respecto de otros, es decir, las representaciones de éstas están subsumidas en las definición de problemáticas sociales, o en la descripción de otros sujetos sociales. Esta percepción sufre un proceso de cambio hacia los noventa a partir de elementos que se relacionan por un lado con las demandas de los movimientos sociales que las reconocen y al mismo tiempo por un grupo de mujeres que desde sus propios procesos, personales e institucionales se movilizan en torno a 
iniciativas de cambio de éstas, así como de la identificación y explicitación de las diferencias, se vive un proceso de reconocer a "otro" sujeto social, a la mujer y luego un proceso de identificación y diferenciación de "esa" mujer, hacia otros diferenciados "las mujeres".

Para las hacedoras de políticas sociales, en los ochenta, no se distingue a las mujeres, no se producen políticas diferenciadas, ellas están contenidas en la población identificada desde la pobreza, los recursos, las estrategias y las políticas sociales se orientan a la pobreza sin diferenciar especificidad de las necesidades.

En la década de los noventa se produce una reflexión crítica, se plantea la necesidad de identificar las especificidades de los grupos a los que se orientan las políticas sociales para asegurar la eficiencia de éstas, 'los mismos planificadores sociales ya se dan cuenta de que con estas políticas al bulto, digamos, no logran la superación de la pobreza, la superación de la discriminación".

Posteriormente se reconoce a las mujeres, “...yo creo que ha habido un avance en qué, en que la mujer se constituye más como un sujeto social."

Para los y las hacedoras de políticas sociales, las mujeres, han sido inconscientes, no han identificado ni comprendido la discriminación de que son objeto, esta situación cambió a través de un "proceso de convencimiento, de concientización", que ha permitido que las mujeres tomen conciencia, se apropien del conocimiento de su situación y se hagan cargo de ésta. La invisibilidad se liga a la idea de falta de conciencia.

Es la institucionalidad en la década de los noventa, quien se hace cargo de potenciar este cambio en las mujeres, es a través de la institucionalidad que se potencia el conocimiento de las mujeres respecto a sus propios derechos, "...el Servicio Nacional de la Mujer, muestra lo que existe, da nuevas alternativas y propone modificaciones a la Ley y se empieza con una fuerte campaña de derecho a partir del año pasado, o sea, para que las mujeres sepan: existe esto, existe esto otro, existe no sé qué, acá, y aquí es donde ustedes necesitan moverse para exigir que esos derechos se cumplan, porque hay cosas que las mujeres de repente no saben o no sabían, porque se promulgaron leyes, pero no hubo la suficiente discusión...". Se parte de la idea, de que las mujeres no saben, desconocen su condición de sujeto social, de sujeto de derechos; es la institucionalidad a partir de esta percepción elabora propuestas de modificación y de reconocimiento de derechos, como así mismo la promoción y conocimiento de éstos para que las mujeres, la sociedad se apropien de ellos, de ésta manera las mujeres saben, tienen conocimiento, exigen.

Es importante destacar que este proceso de cambio de las mujeres ha estado apoyado por una parte por los procesos sociales generados en el país, de reconocimiento de los derechos y el reconocimiento de las mujeres como sujetos sociales así como también a partir de las estrategias desarrolladas por la institucionalidad que han apuntado principalmente a devolverle la capacidad de ser/hacer a las mujeres, a través modificar la situación de pobreza de las mujeres, ejemplo de ello ha sido el programa de mujeres jefas de hogar, que luego fue implementado como política social, "....efectivamente el programa tiene un gran éxito que tiene que ver con el empoderamiento de las mujeres, con el aumento de la autoestima, con el aumento de su fuerza y de su entendimiento personal...". Es un proceso de ida y vuelta, en donde los sujetos mujeres son reconocidos, se les apoya, se les empodera, se les devuelven las capacidades, conocimiento, poder sobre ellas mismas, sólo en la posibilidad de interlocutar con un sujeto se generan intervenciones. 
A partir de esta representación de mujeres activas, conscientes, se espera que puedan constituirse en interlocutores de manera que participen y generen el movimiento social necesario que permita la identificación de las necesidades específicas, "“...desde hace algunos años (...) alrededor de cuatro años que se ha hecho como bastante énfasis en la participación de las mujeres, tanto las mujeres temporeras, las mujeres jefas de hogar, así de especializado y a la vez todas las mujeres también...”.

Los cambios en las percepciones la opinión pública, el movimiento que se produce es fuente de cambio, la presencia de las mujeres, la visibilización de éstas en lo social, en lo público genera transformaciones; "...empieza a generar opinión pública sobre lo que son las mujeres, cómo visten las mujeres, cómo piensan, cómo opinan, cómo van..."

La visibilidad, la presencia genera cambio en las percepciones del entorno, la que permite las aperturas en éste. “...hay mujeres que sin ser organizadas y sin tener el respaldo de nadie, sin embargo por el cargo que ha ocupado y por la responsabilidad que tiene empieza a tener visibilidad y empieza a generar opinión pública; o sea, de que repente una empresaria, una gerenta general de la empresa no sé cuánto y $\mathbf{n}$ convoca a nadie, 0 sea jamás tendría ningún poder de organización, pero por el cargo que ocupa y por la importancia que eso tiene...".

Resulta interesante destacar que las distinciones realizadas por las hacedoras de políticas sociales orientadas a las mujeres señalan que tanto los temas de participación y autonomía han estado presentes, sin embargo resulta interesante destacar que esto no ha sido suficiente como para instalar la temática, ni tampoco instalar las aperturas necesarias para ello, "...el tema de la participación y ciudadanía estuvo siempre, el tema de autonomía económica de la mujer estuvo siempre, el tema de ejercicio del derecho estuvo siempre."

El reconocimiento de las mujeres como sujetos sociales ha significado cambiar la imagen de dependencia respecto de otro, que fue una característica importante en la década pasada, “...las mujeres ya no le deben obediencia al marido, porque se cambió....”.

Este cambio se evidencia en que las mujeres se permiten volcarse sobre si mismas, generar identidad desde, para y por si mismas, "....yo creo que las mujeres que realmente trabajan consigo mismas como mujeres y que no están compitiendo con el hombre, ni están tratando de quitarle el puesto, sino que ellas paradas sobre sus propios pies... o sea, si todas aunáramos fuerzas y realmente trabajáramos, sería un viraje pero espectacular, espectacular." Desde el discurso se infiere una nueva distinción de mujeres, que se encuentra en proceso de construcción y que se elabora a partir de la imagen que las propias mujeres generan desde si mismas, reconociéndose el valor de este proceso de diferenciación y distinción tanto en lo objetivo como subjetivo.

Las hacedoras de políticas sociales distingue a mujeres diversas "yo creo que hay varias, yo creo que no hay una sola mujer. Porque realmente que la situación económica, el grupo etáreo, todo eso marca grandes diferencias, yo creo que no es la mujer, yo creo que son las mujeres en situaciones distintas".

Las hacedoras de políticas construyen imágenes variadas de mujeres, “...la imagen de la mujer es una imagen diversa, todo tipo de mujer: mujer pobre, mujer de clase media, ejecutiva, etcétera...", estas diferencias son construidas desde las condiciones 0 características de las mujeres respecto a si mismas o sus entornos y las relaciones que establecen con otros sistemas. 
Estas mujeres se distinguen en base a los diferenciadores sociales, culturales, económicos, subjetivos, etc, y éstos a su vez pueden se recategorizados "...es que me cuesta hablar de una sola imagen, yo creo que hay muchas, muchas, muchas, en estas tres grandes categorías hay subgrupos distintos..."

La autonomía parece constituirse en un aspecto relevante, como he señalado anteriormente las mujeres han sido definidas respecto a otro, sin embargo a fines de los noventa desde los y las hacedoras de políticas sociales las representaciones de mujeres asociadas a lo económico se construyen y reconocen en dependencia de otro. La imposibilidad de que las mujeres, independiente de la condición social en la que se encuentre cuente con la autonomía económica y social "...de repente hay mujeres que aparentemente son del nivel socioeconómico más alto, pero dependen de que el marido le ponga la plata en el banco y esa mujer no es plenamente sujeto social." Para ellas se requiere un quiebre que permita completar el proceso de autonomía de las mujeres.

En los procesos de construcción de sujetos desde las hacedoras de políticas sociales, se reconoce que las políticas sociales han estado orientadas a un determinado grupo de mujeres, atribuyéndoles a ellas ciertas problemáticas, sin embargo a fines de los noventa se produce la necesidad de incorporar nuevas distinciones que den cuenta de la complejidad y diferencias de esta diversidad que ha sido reconocida en un inicio, "Yo creo que con las mujeres de clase media y las mujeres de clase alta, esas faltan digamos."

Finalmente respecto a las construcciones de sujeto, se identifica la necesidad de generar un cambio de visión, dejar la conceptualización de vulnerabilidad que centra las diferencias en las carencias, en el daño de que puede ser objeto, “... las mujeres no pueden ser vistas desde su marginalidad, sino que deben ser vistas desde su potencialidad, y eso de alguna u otra manera cambia el concepto de cómo llega a las mujeres, no desde la vulnerabilidad, sino desde sus potencialidades, porque si parte de la vulnerabilidad está partiendo con un handicap en contra...", se requiere avanzar en el reconocimiento de éstas como sujetos integrados, con potencialidades, capacidades de ser y existir, desde el poder y las facultades de ellas.

(ii) Elementos a través de los cuales las estructuras estatales resignifican a los sujetos emergentes. (cómo)

Tabla resumen:

\begin{tabular}{|l|l|l|}
\hline Elementos significativos & $\begin{array}{l}\text { Elementos del proceso en } \\
\text { el ESTADO }\end{array}$ & $\begin{array}{l}\text { Elementos del proceso en } \\
\text { la SOCIEDAD }\end{array}$ \\
\hline Antes de los noventa & $\begin{array}{l}\text { No es prioridad } \\
\text { Dependencia } \\
\text { No estaba en el gobierno } \\
\text { Sujetos, mujeres } \\
\text { invisibilizadas en la política } \\
\text { del "bulto" }\end{array}$ & $\begin{array}{l}\text { No es prioridad } \\
\text { Dependencia } \\
\text { Está más en lo privado. Hay } \\
\text { vergüenza de ciertos temas } \\
\text { Participación política } \\
\text { Preocupación de la situación } \\
\text { de las mujeres en ONG, } \\
\text { organizaciones, etc. } \\
\text { Movimientos sociales }\end{array}$ \\
& & a los temas ye pone el tema en lo \\
\hline
\end{tabular}




\begin{tabular}{|c|c|c|}
\hline & $\begin{array}{l}\text { situación de las mujeres. } \\
\text { Pasa a ser un tema del } \\
\text { Estado crea } \\
\text { El Estado } \\
\text { institucionalidad } \\
\text { Conciencia } \\
\text { Se pone el tema en la } \\
\text { agenda pública } \\
\text { Posicionamiento al interior } \\
\text { de la estructura } \\
\text { Se apunta a un cambio } \\
\text { cultural } \\
\text { Voluntad política } \\
\text { Se reconoce diversidad, } \\
\text { heterogeneidad, se visibiliza } \\
\text { Reconocimiento } \\
\text { constitucional } \\
\text { Se elaboran leyes } \\
\text { específicas } \\
\text { Falta comprensión de la } \\
\text { situación de las mujeres } \\
\text { Focalización de las políticas } \\
\text { sociales (mujeres + pobreza) }\end{array}$ & $\begin{array}{l}\text { político } \\
\text { Tema internacional puesto } \\
\text { en la agenda mundial } \\
\text { Se pone el tema } \\
\text { socialmente. Se amplifica } \\
\text { radio de acción } \\
\text { Prioridad/abre al entorno } \\
\text { Rompe mito privado/público } \\
\text { Se instala en el sentido } \\
\text { común de las personas } \\
\text { Mujeres pierden vergüenza } \\
\text { respecto de ciertos temas } \\
\text { Mujeres pasan a conformar } \\
\text { el Estado } \\
\text { Se reconoce diversidad, } \\
\text { heterogeneidad }\end{array}$ \\
\hline Fines de los Noventa & $\begin{array}{l}\text { Sensibilizar- estructura del } \\
\text { Estado (cambio cultural) } \\
\text { Permea los medios de } \\
\text { comunicación (cambio } \\
\text { Cultural) } \\
\text { Transversaliza el tema } \\
\text { Mayor comprensión de la } \\
\text { situación de las mujeres } \\
\text { Enfasis y ampliación de las } \\
\text { políticas sociales (mujeres+ } \\
\text { trabajadoras+ clase media, } \\
\text { alta) } \\
\text { Se promueve la autonomía } \\
\text { económica } \\
\text { Comisión interministerial. } \\
\text { Enfasis en política social con } \\
\text { perspectiva de género } \\
\text { Intersectorialidad/trabajo } \\
\text { conjunto. }\end{array}$ & $\begin{array}{l}\text { Tema de todos: } \\
\text { Traspaso a otros actores. No } \\
\text { es un problema individual } \\
\text { sino social } \\
\text { Cambio cultural } \\
\text { Falta mayor interlocución del } \\
\text { Estado con la sociedad civil. } \\
\text { Micromovimientos, } \\
\text { globalización }\end{array}$ \\
\hline
\end{tabular}

En términos generales los elementos de resignificación de los sujetos emergentes observados por los y las hacedoras de políticas sociales dirigidas a las mujeres, están contenidos en los procesos de resignificación contenidos tanto en las distinciones observadas al interior del Estado como en la Sociedad.

Respecto de los elementos a través de los cuales los hacedores de políticas sociales dan cuenta de las mujeres; es posible identificar procesos que aparentemente se retroalimentan y 
van generando transformaciones tanto en el Estado, como en la sociedad y viceversa; estos elementos se elaboran dialécticamente generando un proceso.

En este sentido las representaciones de las mujeres en los años ochenta, aparecen sustentadas en la invisibilidad de las mujeres como sujetos, a los que podríamos asociar el tipo de estructura y de política social que se desarrolla, la política del bulto como he señalado anteriormente. Las mujeres no ocupan un lugar tanto dentro de la estructura del Estado como tampoco son distinguidas en las diferencias (45). Socialmente se produce algo similar, la demanda respecto de los derechos, se sumerge en la demanda de la sociedad en general, demanda de los derechos de las personas para el restablecimiento de las condiciones de libertad y democracia. Los temas ligados a las mujeres quedan en la esfera de lo privado. En este contexto las ONG orientan su trabajo hacia las mujeres, en donde determinados temas, como la situación social, económica, de salud, son tratados, se interviene, desde este punto se articulan procesos que dejan de manifiesto la diversidad de realidades de las mujeres.

Con la recuperación democ rática, el Estado se abre al tema, lo incorpora en la agenda pública, apunta a un cambio cultural, creando institucionalidad para hacerse cargo de la temática de las mujeres. Se proponen cambios legislativos, reconocimientos constitucionales orientados a a elaboración y trabajo. En este contexto se reconoce que al interior de la propia estructura del Estado y de los gobiernos, falta sensibilidad y conciencia respecto de la situación de las mujeres. Las políticas orientadas a las mujeres son focalizadas a la superación de la pobreza de las mujeres.

Este cambio en las representaciones al interior del Estado, tiene un correlato social, en donde las distinciones se orientan a que el tema de las mujeres, es instalado en la agenda pública, se abre la discusión. Desde las hacedoras de políticas sociales se identifica en el correlato social una propuesta del tema en lo público, pasa a ser un tema público, político y se produce un cambio en el sentido común de las personas.

Los elementos presentes en los ochenta, tanto en el contexto social, político, como estatal, potencian las condiciones de demanda social articulada, la que a inicios de los noventa permite situar en el Estado parte importante de estas demandas. A partir de esto puedo afirmar que se producen dementos de resignificación que en conjunto generan un proceso dialéctico de resignificación tanto estatal como al interior de la sociedad. Es decir es posible identificar elementos potenciadores así como también obstaculizadores tanto internos como externos al Estado que van configurando las distinciones de mujeres.

Ya a fines de los noventa, los procesos asociados a las mujeres, tanto dentro del Estado como en la sociedad, se transversaliza, permeando la estructura, intentando un cambio cultural, se orientan políticas sociales con un enfoque de género. Socialmente se produce un mayor reconocimiento del tema, como tema de todos, la transversalidad, la toma de conciencia, se amplía. Al mismo tiempo se reconoce desde la institucionalidad la necesidad de contar con una mayor interlocución y control social de los procesos de resignificación y políticas que se generan desde el Estado. El tema de las mujeres, tanto para los generadores de políticas sociales, como para la sociedad no se restringe a la pobreza, es un tema que atraviesa la sociedad, nacional y también internacional así como los espacios locales.

A partir de los elementos señalados anteriormente quisiera detenerme en cada uno de ellos con el objeto de dar cuenta de la articulación de elementos que construyen resignificaciones en las estructuras. Como he indicado, en el cuadro anterior se resumen algunos elementos con objeto de dar un orden, detallaré algunos aspectos respecto de los momentos en que estos son 
elaborados y a la vez daré cuenta de la relación existente entre articulación de elementos de la propia estructura y de la sociedad que construyen un proceso articulado de construcción de representaciones.

\section{Elementos antes de los noventa}

Desde el material recogido, se identifica un elemento importante que define este momento, la situación de las mujeres no es reconocida como un prioridad por parte del Estado ni por las políticas sociales. En este período se asume desde el Estado la política del bulto, la política social es orientada a la población pobre, a través de programas con el fin de paliar la situación de pobreza de éstos sin diferenciaciones sociales, regionales, culturales, de género.

Desde las distinciones señaladas por los y las entrevistadas, destaca que la imposibilidad de atender a las diferencias se debe a un contexto social, político que no sólo está presente en el país sino también en Latinoamérica, la presencia de dictaduras, deslegitimaría las diferencias, y establecería estrategias para abordar la pobreza desde acciones masificadas orientadas a mantener y sostener las transformaciones económicas, los procesos de ajuste implementados en la región. Desde esta lógica se hace imposible la construcción y reconocimiento de diferencias desde al aparato público.

En la sociedad el tema no reviste de importancia, excepto para aquellos grupos o núcleos que desarrollan un trabajo con las mujeres (universidades, ONG, etc). Socialmente las mujeres están/ son invisibilizadas, encubiertas por la problemática social y de derechos humanos que afecta al país. Las organizaciones no gubernamentales, así como la intelectualidad, la academia tiene un rol importante en, por un lado, recoger las discusiones internacionales, así como también las demandas y realidad de las mujeres al interior del país. Se constituyen en una ventana, desde donde se percibe y estructura una realidad que aparece invisibilizada.

Para las entrevistadas, el papel de articulación y de apertura jugado por las organizaciones no gubernamentales es prioritario, “... las ONG tuvieron un papel fundamental, o sea, si no hubiera sido por las ONG de verdad que las mujeres no hubieran tenido ninguna ventana para abrir y las ONG lo ponen en el tapete nacional, pero también en el tapete internacional...". El espacio que se abre desde la discusión nacional e internacional permiten de alguna manera, la apertura, respecto del tema de las mujeres como un tema revestido de particularidades. La discusión, los estudios e intervenciones realizadas, orientan un reconocimiento a que las mujeres han sido distinguidas, respecto a otro, cumpliendo roles sociales, se pone en la discusión pública las acciones que se ejercen sobre ellas desde las políticas sociales.

Este período está marcado por la invisibilidad de las mujeres, contenida en la política del bulto, invisibilidad que se rompe desde lo y en el inicio de la década por la democratización de las relaciones. Este período también se sostiene en los procesos propios de los sujetos, “....se han ido visibilizando, o sea se han hecho patentes, porque las mujeres se han hecho más conscientes de cuáles son sus derechos, porque las mujeres no sabían cuáles eran sus derechos, no tenían idea, y ni siquiera sabían dónde podían acudir...". Orientados a la toma de conciencia, conocimiento, apropiación de los derechos de las mujeres en la década de los noventa.

El movimiento de mujeres, el movimiento feminista logra, a nivel internacional, poner ciertos temas que luego se instalan en las discusiones y tratados internacionales lo que repercute a nivel interno. 
Socialmente los temas relativos a las mujeres en los años ochenta, son identificados en el ámbito de lo privado. Desde el discurso de las hacedoras de políticas sociales los problemas que afectan a las mujeres son vividos como únicos, con vergüenza, ocultando lo que les sucede, sin comprender lo que les sucede, “...hay un grupo de mujeres que todavía vivían la situación de ser golpeadas por ejemplo como del ámbito muy privado, con vergüenza de decidirlo, entonces cuando se pone en el tapete empieza a haber como todo una toma de conciencia...".

A fines de los ochenta, la participación de las mujeres, permiten articular no sólo el enfrentamiento conjunto de situaciones de pobreza, desempleo, violencia, trabajo temporal, sino también permiten la elaboración de demandas y de estrategias específicas que son las que sostendrían a juicio de las entrevistadas el posicionamiento de la demanda de las mujeres en la década siguiente.

La movilización e instalación del tema fuera del aparato estatal son insumos importantes para la elaboración de una demanda clara y específica desde los movimientos de mujeres,“'...aquí, en el proceso de reconstrucción del tejido social en Chile, las mujeres fueron muy importantes y cuando se comenzó a acercar la posibilidad de ir hacia la recupe ración de la democracia, las mujeres negociaron, negociaron bien como... o sea, nosotros hemos puesto todo esto, nosotros les exigimos de vuelta a los partidos políticos de la Concertación que se genere este Estado, lo hicieron bien....”.

En síntesis, estos movimientos son incluidos en los trabajos de las comisiones de la concertación de mujeres por la democracia, trabajos que intentan posicionar e interpretar a una gama amplia de mujeres del país. A través de las propuestas se intenta elevar la problemática de las mujeres a la política nacional, de modo de sobre esta sustentar un programa de trabajo para el futuro gobierno democrático. Las reflexiones recogidas durante fines de los ochenta, se orientan a la focalización de las acciones, de políticas sociales, con el objeto de atender las problemáticas que afectaban a las mujeres. Las discusiones tanto nacionales como internacionales permitieron elaborar una propuesta desde el gobierno que se implementó en los noventa.

\section{Procesos a inicios de los noventa}

Como señalé anteriormente la generación de una propuesta elaborada desde los actores que contribuyeron a un trabajo con las mujeres durante los ochenta, intelectuales, universidades, ONG, militantes, partidos, permitieron; a partir de la experiencia nacional e internacional; construir una propuesta que orientará los primeros años del gobierno de la concertación, este proceso de articulación en las distinciones cobra un valor importante en el discurso de los responsables de elaborar políticas sociales.

Se reconoce que esta propuesta es incorporada por el Estado. Las mujeres organizadas en torno a la concertación proponen la construcción de procesos y estructuras que posibiliten el reconocimiento de la temática y los requerimientos de las mujeres, “...hasta el año noventa el tema de la mujer fue tratado por ONG, por organismos, o por grupos feministas de la sociedad civil, sin embargo, desde el año noventa y uno que se crea el Servicio Nacional de la Mujer, el tema empieza a ser un tema del Estado...".. Esta estructura, desde el habla 
de las entrevistadas es la propuesta transformada de las experiencias y estructuras presentes el país y que a su vez recogen experiencias de otros países democráticos y desarrollados.

Las condiciones internas, la instalación de un gobierno democrático, además de las condiciones y requerimientos de los países y organizaciones internacionales posibilitan las aperturas, por un lado hacia "nuevos sujetos", a un modo diferente de orientar las políticas sociales, de focalizar, y al mismo tiempo la apertura estructural que incorpora en sus distinciones a nuevos sujetos. El trabajo realizado durante los ochenta, además de la experiencia acumulada sirven de respaldo para la construcción de este nuevo escenario, estos elementos "fueron demostrando que era necesario ir focalizando esos aspectos ....y cuando ya asume el primer gobierno democrático ya había casi como algo como semi armado, o sea, cuando se dijo: hagan la propuesta, fue como... no fue tan difícil armar una pequeña propuesta".

Estos primeros esfuerzos identifican a diversos actores sociales así como problemáticas emergentes, “...el Estado empieza a tener un foco distinto para mirar las políticas, que le llamaba como la política del bulto, 0 de la talla única que después empieza a diversificarse...". Es posible interpretar que el Estado se abre, se estructuran nuevas comunicaciones, relación sujeto entorno.

Para las entrevistadas la experiencia, ya detallada, se constituye en instrumentos de navegación, que otorgan claves; para la instalación y transformación estructural bajo condiciones nacionales e internacionales que establecen un marco.

La democratización del gobierno, la democratización de las relaciones, permiten asentar y generar procesos de reconocimiento de la otredad y una diferenciación en las prioridades, los objetivos que como país y sociedad se plantean. "Yo creo que en un momento al democratizarse las sociedades, han logrado ampliar también su agenda política...". Las prioridades políticas y sociales se centran en los grupos excluidos, como parte del reconocimiento de las diferencias.

Las aperturas no sólo institucionales sino también personales, las voluntades políticas e intelectuales, permiten la creación de una nueva institucionalidad.

Para las entrevistadas el contexto generado por los acuerdos internacionales adscritos por Chile, así como la voluntad política dispuesta a través del gobierno de la concertación, permite consolidar las iniciativas necesarias que garanticen la eliminación de todas las formas de discriminación firmadas en el CEDAW, el país requiere sustentar y consolidar política y estructuralmente la incorporación de las mujeres como sujetos sociales, como sujetos de derecho. Como he señalado anteriormente a fines de los ochenta y con fuerza a inicios de los noventa se decantan los esfuerzos realizados para un reconocimiento de los derechos de las mujeres. La constitución de la estructura del SERNAM, potencia la instalación del tema a nivel estatal y también social, "el SERNAM nace entonces como una necesidad como país que ha ratificado una convención internacional y que necesita un organismo que vele por esa convención internacional, entonces el SERNAM nace y de hecho empieza a hacer toda esta promoción de políticas (...) coordina y se empieza a mover y a agilizar y a poner el tema dentro del Estado".

La institucional tiene un doble rol, por una parte debe permear, socializar la mirada, las distinciones no sólo al interior del aparato público, sino también político, así también llevar o devolver, permitir nuevas distinciones desde la sociedad. A través del discurso de las entrevistadas se reconoce un proceso en donde en cada una de las etapas de los gobiernos 
se han instalado intencionalidades que permitan ir avanzando por la no discriminación de las mujeres, hacia el reconocimiento pleno de sus derechos, "...es un tema que está posicionándose, a mi modo de ver son procesos y que uno de los logros que esta institución ha tenido, es ponerlo en la agenda pública, y que sea mirado como un tema de política pública para hacer transformaciones concretas a través del Estado...". Esta nueva categoría social, obliga a la institucionalidad a revisarlo realizado, a reconocer la necesidad de que el tema se sitúe en la agenda pública, que permee al resto de la estructura estatal, jurídica, social.

Este posicionamiento requiere un activo apoyo por parte del Sernam, quien reconoce las debilidades de la estructura estatal, de sus funcionarios. El cambio que significa romper con la invisibilidad implica un esfuerzo y una evaluación de los avances, de las estrategias necesarias para implementar, 'los mismos sectores o ministerios, son muy débiles en asumir este tema, tanto desde el punto de vista teórico, como desde el punto de vista de su comprensión transformadora que esto tiene y... es un tema que está posicionándose a mi modo de ver, o sea que está introduciéndose en el Estado y que este es un proceso, precisamente porque significa cambios culturales, o sea, cambios culturales al interior de las organizaciones del Estado, como de las personas que hacen la política, como de los actores...".

El logro de la política de los inicios de los noventa es poner en la agenda pública, lo que se encontraba en la calle, aquello que aparecía como circunscrito a la vida privada de las personas, lo que se discutía en la vida cotidiana de éstas, "lo que está en la calle, lo que está en la discusión cotidiana", es decir se puso en la agenda institucional del gobierno, como prioridad el tema de las mujeres, debiendo reconocer en ello un esfuerzo importante desplegado por una parte a generar discusión, reconocimiento y valoración de la temática, así como también a la articulación y consolidación de discusión pública, de transformar el sentido común desde y en la ciudadanía.

Es importante destacar que las observaciones realizadas por los y las entrevistados dan cuenta de que el primer proceso de instalación de la temática de la mujer, significó un esfuerzo para poner en la conciencia, en el sentido común de la sociedad el tema, y también un esfuerzo interno, en la propia institucionalidad. Este esfuerzo también ha significado dar cuenta de las resistencias, mitos y prejuicios que operan tanto en la institucionalidad como en la sociedad, claro ejemplo de ello han sido las dificultades para la elaboración de leyes orientadas a la protección de las mujeres, tanto en el ámbito laboral, como familiar.

La identificación de esta temática como una temática transversal, de alguna manera queda reflejada en los diagnósticos y las intenciones del Plan de lgualdad de Oportunidades para Mujeres 1994-1999. Al menos dos elementos importantes que dejan en evidencia esta nueva mirada se refiere al tema de la instalación y reproducción de imágenes y estereotipos acerca de mujeres y hombres, a través de los medios de comunicación y los procesos educativos (46).

La ubicación de la temática de las mujeres en lo público, no sólo ha significado la instalación de un nuevo tema, de una nueva preocupación política y social para el país, sino también ha significado un reconocimiento de las resistencias sociales y culturales que requieren de un esfuerzo centrado en la generación y potenciación de cambios culturales orientados tanto a la propia estructura, la sociedad civil, como a los que hacen política social desde otros sectores, a los políticos, etc. Esta preocupación y énfasis de hace más evidente a fines de los noventa de acuerdo a lo señalado por las entrevistadas. 
Como hemos visto el proceso es más bien, este se constituye como un proceso que se define como permear tanto las estructuras como el tejido social. Este permear a las estructuras se enfrenta a dificultades que trascienden a las definiciones realizadas desde el Estado, este se enfrenta a dificultades en el correlato estructural y social. Es decir, se produce un desfase entre los avances y planteamientos de la estructura, en este caso el SERNAM y el resto de las estructuras, es un desfase en la mediación de las estructuras y las personas que son parte de esta estructura, se produce un nudo ciego, que entorpece los procesos, los detiene, que cuesta traspasar, penetrar y generar ciertas claridades.

Quisiera enfatizar que la prioridad del tema esta determinado por quienes establecen las distinciones es decir, el proceso de colocación la situación de las mujeres, depende de para quienes, tanto dentro como fuera de la estructura dificulten o favorezcan este proceso. Se produce un desfase entre: las políticas sociales, quienes operan las políticas sociales, los receptores de éstas, la sociedad civil.

Respecto del punto anterior es importante destacar la propuesta de promoción de una imagen social y plural y no discriminatoria de las mujeres tanto en lo cultural como comunicacional. Se plantea que las mujeres como sujetos sociales y culturales y su relación con los medios de comunicación tienen un impacto en el desarrollo y democratización del país. El documento Plan de Igualdades de la década plantea que los medios de comunicación social "son elementos fundamentales en la configuración del imaginario colectivo, en el cual están representados identidades, roles, actividades y relaciones que se establecen entre los diversos sujetos sociales. Entre estas imágenes se encuentran lo que son y lo que deben ser las mujeres, tanto en sus aspecto subjetivos como en lo que se refiere a su participación concreta en las diferentes actividades de la sociedad."

En la sociedad civil, el tema de las mujeres a inicios de los noventa, de acuerdo a lo recogido en las entrevistas, es un tema entre mujeres, que luchan, conquistan nuevos espacios. En la lucha contra la dictadura se ganan espacios. La transición, y la apertura de contextos de valoración del otro, de espacios democráticos permite el que las mujeres se hagan cargo y ocupen espacios en la institucionalidad que se abre desde el Estado. La estructura que emerge contienen en si misma la demanda y a los propios sujetos, mujeres.

Como elemento relevante, la generación de este nuevo Estado, desde las observaciones realizadas, es producto de la construcción de un tejido social que incorpora en su propia estructura como preocupación y como articulador a las mujeres. Éstas acercan desde el movimiento social en general, la demanda especifica y comprometen desde la negociación que realizan con los partidos políticos, la incorporación de la situación de las mujeres con el objeto de cambiar las condiciones de discriminación de las mujeres. Es desde este curso de acción que se incorpora en este nuevo Estado la diversidad, diversidad constituyente e invisibilizada por la sociedad.

\section{Procesos a fines de los noventa}

Quisiera volver sobre un punto que surge como relevante a fines de la década. A partir de la identificación del nudo ciego, (que se refiere a las dificultades que se producen al interior del sistema estatal, político, jurídico, la instalación del tema, en donde se dan contradicciones e incoherencias) la estructura define un cambio en las estrategias, desde el SERNAM, para permear a la estructura y a la sociedad desde diferentes ángulos. 
La identificación de "los nudos ciegos", permite definir desde las hacedoras de políticas sociales que no sólo es necesario poner determinados temas en la agenda pública, sino también, trasversalizar el tema de las mujeres, para ello se requiere la intervención en la propia estructura, así como también en el sistema comunicacional; de modo de complementar las estrategias y desarrollo de programas y políticas sociales que incorporen una mirada más clara de la situación de las mujeres y desde allí se orienten políticas diferenciadas.

A fines de los noventa las observaciones de los hacedores de políticas sociales es que el tema de las mujeres ha logrado permear, atravesar a distintos sectores, se afirma entonces que el tema no sólo está en la conciencia de los sectores de izquierda, sino también se ha instalado en los sectores de derecha, los temas están mucho más puestos.

La evaluación del proceso de instalación de la temática de las mujeres a fines de la década, incorpora un análisis crítico de la falta de un movimiento de mujeres que permita evaluar y retroalimentar la política dirigida a las mujeres. Se produce la constatación de una carencia en la interlocución con el mundo social de las mujeres, lo que limita la posibilidad de diálogo y discusión permanente con la institucionalidad, de manera de evaluar las políticas sociales implementadas.

Esta carencia en la interlocución es explicada como producto por una parte de que las mujeres que formaban parte de los movimientos y organizaciones no gubernamentales se incorporan a la institucionalidad y por otra parte, la disminución de instituciones no gubernamentales que se ocupen de temáticas relativas a las mujeres, lo que se traduce en la dificultad para elaborar nuevos discursos de las mujeres desde procesos de intervención, investigación, fuera del aparato estatal.

La nueva reflexión destaca también que las mujeres no sólo son objeto de acción, sino también que estas deben situarse como sujetos de procesos más allá de la estructura del Estado, de manera de evaluar las acciones y generar procesos hacia nuevas distinciones e intervenciones.

Al interior de la estructura se reconoce la necesidad de estar en permanente dialogo, como estrategias para permear la estructuras y al mismo tiempo para sostener la temática de las mujeres transversalmente, desde allí estas instancias pretenden sacarle las comillas al tema. Es decir, instalar el tema de modo de avanzar colectivamente, hacia una política pública que incorpore en su mirada y en su accionar una mirada de género que apunte al cambio en las relaciones sociales.

A fines de los noventa se identifica la necesidad de que el tema de las mujeres sea parte de los intereses, preocupaciones de los otros ministerios, se intenta que éstos asuman como propio distinciones que permitan políticas sociales desde el género. Los últimos esfuerzos se centran en que tanto las estructuras como los funcionarios se apropien del tema.

Desde el discurso se destaca la necesidad de transversalizar el tema, que este deje de ocupar un espacio especial o esté en manos de parte del Estado o sociedad, esta mirada beneficiaría a la sociedad en su conjunto "transversaliza a todo tipo de mujeres, entonces ahí, es en beneficio de la mujer en general" .

Desde las entrevistadas emerge la necesidad de generar por medio de diversas estrategias “...a nivel del Estado ... una masa crítica que nos ayuden a hacer estos cambios, porque (...) necesitamos transversalizar este tema....y solamente los van a tomar si tienen claridad de lo que hay que hacer con esos temas...". La incorporación de estos elementos 
se verá reflejada en las incorporaciones programáticas que se realicen, así como en las inversiones y presupuestos ministeriales.

Se destaca la necesidad de resituar el tema de género, el cual no sólo se circunscribe al tema de las mujeres de sectores específicos "entonces, si bien es cierto hemos estado como preocupadas de temas focalizados y estamos viendo una mirada como más universal para llegar a todas con sus expresiones particulares, pero que no sólo fuera en sectores chiquititos, sino que esto pudiera abarcar mucho más", en la idea de ampliar la mirada no sólo a la totalidad y particularidad de las mujeres, sino en la complejidad de las relaciones entre hombres y mujeres, abriéndose la reflexión respecto a la masculinidad.

Como he indicado desde la observación de las observaciones, esta mayor comprensión de la situación de las mujeres, implica una adecuación del sistema, de manera de sumar esfuerzos que permitan la transformación del sistema social, político, jurídico, estatal, para ello se identifica la necesidad de centrarse en los procesos de sensibilización, "de poner en la opinión pública, a través de un servicio comunicacional muy fuerte los distintos temas que tienen que ver con... la diferencia entre hombres y mujeres, la igualdad de oportunidades, etc." el ir permeando a la sociedad, a la opinión pública, hacia procesos que generen opinión pública, masa crítica, requiere, así mismo, permear los medios de comunicación.

Desde lo identificado en el estudio el enfoque respecto a la temática cambia, ya no se miden sólo los costos sociales, emocionales de la discriminación, sino "cómo hacer más eficientes lo de las platas, más que el tema de todos los otros costos, sociales y culturales que tiene el tema de la discriminación en estos mome ntos". Este es un elementos que emerge en la lógica de la época "que es este giro como en el tema del costo- eficiencia de la discriminación, y que yo creo que ese sí que ha sido un elemento agregado en esta última década".

Un elemento importante en el proceso de construcción de distinciones respecto a las mujeres, es por parte de la institucionalidad es el reconocimiento de una tarea orientada al cambio cultural. "SERNAM tiene una tarea de cambio cultural que es muy fuerte...", Se propone modificar, adecuar las construcciones sociales de modo de disminuir las brechas existentes. Se trata de llegar a alterar las distinciones de los sujetos, hombres y mujeres, en su vida cotidiana.

En este proceso dialéctico que es posible distinguir a partir del relato de las entrevistadas, es posible identificar que el la instalación de la temática responde a procesos que se han desarrollado en el mundo. Los temas de tolerancia y diversidad, son parte de las agendas públicas de los países, desde donde se valoran ampliamente los beneficios y repercusiones sociales, culturales y también económicas de éstas temáticas. La tolerancia, diversidad, el reconocimiento de los diferentes actores sociales, como parte de un discurso que requiere ser incorporado "aparece una cuestión valorada socialmente, porque yo creo que hace muchos años que se han estado tratando de poner, ....empieza a haber una valoración de estos temas, entonces también hace que tú dejes de ser moderno o de ser eficiente o de tener como connotaciones de exitoso, sino pones ese tema en la agenda pública...te estás quedando como fuera de esta gran ola de modernidad, de cambios, de información y eso yo creo que la presión desde lo más sociocultural muy potente en los países."

Un énfasis dado en los últimos años de la década ha estado orientado a generar transformaciones que hagan efectivo la autonomía económica de las mujeres. "...el mejoramiento de la calidad de vida de las mujeres como mujeres y en sus familias, mejorar la participación y acceso a toma de decisiones por parte de las mujeres y la 
autonomía económica que es superación de la pobreza. En eso SERNAM se va a jugar, la idea es que los departamentos funcionales: estudios, comunicaciones, relaciones internacionales, situación jurídica de la mujer, sean capaces de dar cuenta de los requerimientos que surgen en estos ejes..."

La autonomía económica desde lo señalado por las entrevistadas entregaría a las mujeres las facultades para constituirse en sujetos independientes "...hay un énfasis bastante más fuerte de parte de esta Ministra en todo lo que tiene que ver con mujer y autonomía económica...". Este es uno de los ejes importantes que se suman a los desarrollados a inicios de la década, respecto a superación de la pobreza, participación, mejoramiento de las condiciones laborales.

"El tema de tener autonomía económica, una cierta autonomía económica, que no significa, que quiera ser más o menos que el hombre, sino que el saber de que ella puede valerse, que no tiene que depender de otra persona; el avanzar cada vez nás a su autonomía yo creo que es muy importante para sentirse incluida socialmente; es muy distinta la parada de una mujer, de cualquiera sea el nivel socioeconómico...". La autonomía no sólo tendrá que ver con la percepción que la sociedad tenga de las mujeres sino también de las propias distinciones de éstas. Las autonomía se vincula a la posibilidad de acceder, de decidir, de ejercer derechos, de desarrollarse.

Quisiera volver atrás. Para las entrevistadas como he señalado se produce un problema de interlocución del Estado con la sociedad civil, lo que dificulta la evaluación y seguimiento de políticas sociales implementadas. Sin embargo, ellas destacan que en este proceso han sido significativos los aportes desarrollados por un grupo de mujeres, de organizaciones no gubernamentales las que han generado discusión y análisis de las estrategias desarrolladas a través de la generación de indicadores que dan cuenta de elementos que pueden permitir dificultar o facilitar cambios en las distinciones, "hay un movimiento que es una iniciativa que convoca a personas de instituciones sociales y políticas..... ellos han definido lo que se llama el índice de desarrollo de las mujeres... ellas generan todos los años un seguimiento a cómo está el gobierno, cómo está el Estado digamos en relación a las políticas ...han desarrollado un instrumento de control ciudadano para la mujer, se dice que fue una iniciativa de mujeres... tiene indicadores de participación ciudadana y acceso al poder, cómo están digamos, cuál era la meta, los indicadores de voluntad política, está la salud de la mujer, derecho sexual y reproductivo, autonomía económica de las mujeres. Así que ven todos los años cómo el gobierno se está poniendo con los temas que son de las mujeres..."

Parece interesante destacar este elemento en cuanto de alguna manera reconoce que el tema como tema social, no sólo le corresponde a la institucionalidad sino también se reconoce éste como una temática social, en donde se requiere ir generando condiciones de mayor interlocución Estado Sociedad. Sin embargo esta interlocución se ve mediada, a fines de los noventa, por condiciones de estructuración de micromovimientos en el contexto de la globalización y de la emergencia de movilizaciones que se constituyen en respuesta a determinados problemas. Se reconoce un cambio en el entorno social, "...empiezan a surgir micro experiencias que tienen un poder en el espacio de lo micro no más. Entonces de pronto que sé yo, las mujeres que son consumidoras .... tienen logros en función de esa demanda específica y todo, porque pelean y saben con quién peleai y negociai .... en función de una cotización de la demanda de la convocatoria y de la realización y eso pasa no sólo con las mujeres, pasa con todo..". Este cambio en el entorno podría constituirse como un facilitador de los procesos de interlocución y evaluación. 
Desde esta evaluación del entorno social y el reconocimiento por parte de las hacedoras de políticas sociales, de la necesidad de interlocución entre el Estado y la sociedad civil, emerge un nuevo desafío, en donde la política social, la situación de las mujeres, las relaciones sociales de género, se sitúen como temática social no sólo individual, para lo cual tendrá que establecer nuevos mecanismos para permear, posicionar y transversalizar la temática, "...yo pienso que también el Estado va a sufrir una revisión en su forma de hacer políticas, y en su forma de trabajar las políticas, porque las cosas se van a resolver en movimientos más locales, chicos y con actores sociales más... y de otra manera, con una malla social distinta, porque esos son los efectos de la globalización...". 
(iii) Elementos de inclusión/exclusión que utilizan las estructuras estatales y las políticas sociales en los procesos y representaciones de sujetos emergentes. (por qué).

Tabla resumen:

\begin{tabular}{|c|c|c|}
\hline RESPECTO DE & EXCLUSIÓN & INCLUSIÓN \\
\hline Condiciones políticas & $\begin{array}{l}\text { Años 80: Condiciones } \\
\text { políticas desfavorables: } \\
\text { dictadura } \\
\text { No está en la agenda/ no } \\
\text { existe política social/ no es } \\
\text { prioridad }\end{array}$ & $\begin{array}{l}\text { Años 90: condiciones } \\
\text { políticas favorables: } \\
\text { democracia } \\
\text { Se pone en la agenda } \\
\text { social/política/prioridad }\end{array}$ \\
\hline Situación de las mujeres & $\begin{array}{l}\text { No se conoce } \\
\text { No se registra/no hay datos } \\
\text { estadísticos. } \\
\text { No se sabe } \\
\text { Oculto/dependiente } \\
\text { Desprotegidas/sin derechos }\end{array}$ & $\begin{array}{l}\text { Se conoce. Investigaciones } \\
\text { Se sabe } \\
\text { Visible/autónomo } \\
\text { Protegida. Tiene derechos }\end{array}$ \\
\hline Asociado a discriminación & $\begin{array}{l}\text { Discriminación subyacente } \\
\text { Discriminación en la política } \\
\text { pública en el ámbito cultural } \\
\text { Barreras culturales sociales } \\
\text { Tratamiento de la } \\
\text { información y de la imagen } \\
\text { pública ligada a la crónica } \\
\text { roja }\end{array}$ & $\begin{array}{l}\text { Se abren posibilidades en lo } \\
\text { laboral } \\
\text { Acceso a lo público } \\
\text { Se derriban mitos } \\
\text { Cambio en las imágenes de } \\
\text { las mujeres }\end{array}$ \\
\hline Lo cultural y social & $\begin{array}{l}\text { Desigualdades, brecha entre } \\
\text { situación de hombres y } \\
\text { mujeres (laboral, político, } \\
\text { participación en el mercado, } \\
\text { etc) } \\
\text { Lo cultural y social: Lo } \\
\text { privado } \\
\text { Se normaliza, naturaliza } \\
\text { maltrato, discriminación, } \\
\text { subordinación } \\
\text { No hay conciencia de la } \\
\text { situación de las mujeres }\end{array}$ & $\begin{array}{l}\text { Lo cultural y social: se rompe } \\
\text { lo privado se hace público } \\
\text { Se problematiza y cuestiona } \\
\text { lo que aparece como natural } \\
\text { Mayor conciencia social }\end{array}$ \\
\hline $\begin{array}{l}\text { Respecto del sujeto: } \\
\text { mujeres }\end{array}$ & $\begin{array}{l}\text { No } \\
\text { sujeto/privado/dependiente } \\
\text { No ser = no hacer, no } \\
\text { acceso, barreras }\end{array}$ & $\begin{array}{l}\text { Sujeto/situación publica/ } \\
\text { Autonomía } \\
\text { Ser = hacer, acceso, sin } \\
\text { barreras }\end{array}$ \\
\hline
\end{tabular}

En esta parte del análisis me referiré a los elementos contenidos en las estructuras estatales que dan cuenta de la exclusión/ inclusión de las mujeres. De alguna manera se recogerán los elementos planteados anteriormente que configuran las distinciones respecto de las mujeres y que podrán ser articuladas tanto en las acciones como en la reflexión.

Es importante señalar que las distinciones, las comunicaciones que se establecen respecto a los sujetos mujeres, su situación, da cuenta de los procesos de inclusión/ exclusión primaria y 
secundaria así como de los procesos de integración social y los procesos de construcción de identidad. Es interesante destacar que este proceso es observado a través de las observaciones (documentos, discursos, habla) de quienes son responsables de desarrollar políticas sociales orientadas a las mujeres.

En términos generales los principales elementos que se presentan en el cuadro se refieren resumidamente a, como ya he señalado, los procesos sociales y políticos de los ochenta se cierran al reconocimiento de las diversas realidades de los sujetos. El cambio que marca la diferencia, se produce con el retorno de la democracia en donde la sociedad y el Estado se abren a la diversidad, incluyéndola en sus procesos de desarrollo, estructura y prioridades.

Desde el habla de las hacedoras de políticas sociales la exclusión es identificada en cuanto se reconoce una carencia en el conocimiento y registros que se refieran a la situación de las mujeres. Las mujeres no son diferenciadas en los registros y estadísticas en el análisis 0 producción de las distinciones. En la década de los noventa, se reconoce esta carencia y la necesidad de contar con registros que permitan dar cuenta de las condiciones de vida y la situación de las mujeres. Se produce una toma de conciencia que implica una apertura a conocer y visibilizar a las mujeres, lo que permite sostener e implementar intervenciones diferenciadas.

Como he afirmado anteriormente, la invisibilidad de la situación de las mujeres las desprotege, a lo que se suma la inexistencia de una estructura que permita asumir la problemática, ejemplo de ello el maltrato dirigido a las mujeres. El conocimiento de la realidad social de las mujeres abre la valoración social, política y legislativa del tema desde donde las mujeres en procesos de inclusión diferenciados acceden a derechos y a posibilidades de resguardo.

La invisibilidad es sustentada en lo cultural, social y estructuralmente, en la medida que se naturaliza la problemática de las mujeres, es decir, en la medida que las condiciones de exclusión son justificadas y entendidas como connaturales. La situación se revierte en cuanto se pone en lo público, se abre y rompen las concepciones que condicionan y refuerzan la exclusión.

La discriminación de las mujeres como distinción de exclusión de lo social. Las barreras sociales y culturales, así como el tratamiento de una imagen de mujer se identifican como elementos asociados a la exclusión. Sin embargo, a partir de los procesos de apertura, se derriban mitos respecto a las mujeres así como también se producen aperturas sociales y estructurales que permiten la incorporación de éstas en lo público.

Finalmente respecto al sujeto mujeres, la exclusión estaría marcada fundamentalmente por la dependencia de éstas a otro o a otros, las barreras y el no acceso de éstas a lo público y a un desconocimiento de éstas como sujetos sociales. Esta situación tiende a cambiar en la medida que se reconocen los derechos de las mujeres, y se les valora como sujetos sociales, sujetos visibles, que tienen acceso, que son/ están y que hacen.

Sin embargo es posible afirmar que la dependencia de las mujeres se traslada a la estructura, éstas a fines de los noventa dependen de las distinciones que la estructura realice para recibir un reconocimiento simbólico ya que la apertura de la estructura no es capaz de asumir a cabalidad la necesidades que éstas requieren cubrir para la generación de procesos de individualización. En otras palabras si bien las distinciones permiten identificar a las mujeres, en sus características, el sistema no es capaz de asumir los costos de los procesos de individualización de estas, ocurriendo un traslado de la exclusión de las mujeres, es decir un 
procesos de individuación de la exclusión en la exclusión a individuación en la inclusión de la exclusión, ejemplo de ello lo constituyen el reconocimiento de las mujeres jefas de hogar.

Respecto de los procesos de exclusión e inclusión que observan los hacedores de políticas sociales, me detendré a detallar los elementos planteados resumidamente hasta este momento.

A continuación me referiré a los elementos que permiten dar cuenta, desde los discursos (habla, documentos, discursos) elaborados por los hacedores de políticas sociales orientadas a las mujeres; de los aspectos relacionados con la exclusión/ inclusión de los sujetos mujeres.

\section{Condiciones políticas}

Es importante señalar que para efectos de comprender y graficar los procesos de exclusión/ inclusión, ha sido necesario establecer, de acuerdo a las distinciones de las entrevistadas, que el tema de la exclusión y la inclusión no resultan ser procesos rígidos ni estáticos o determinados por un momento histórico, sin embargo a partir de las diferenciaciones más marcadas es posible profundizar y asociar estas a un momento histórico determinado.

Desde las observaciones de las observaciones es posible señalar, como se ha determinado en los puntos desarrollados anteriormente que los sujetos mujeres, no son distinguidos por la estructura estatal, ni por las políticas sociales. Es decir las mujeres accederán y no todas, a los servicios sociales desde la lógica de la pobreza los sujetos mujeres se encuentran sumergidos en las distinciones de pobreza y de políticas masivas

De esta manera, el contexto resulta desfavorable para el reconocimiento de sujetos. Desde la estructura las mujeres son sujetos inexistentes, no están por tanto en las agendas políticas, ni en las prioridades.

El sistema social y político ha reproducido las distinciones respecto de los sujetos mujeres, que no reconocen en éstas su condición de sujetos "...qué año... mil cuatrocientos no sé qué, todavía se discutía al interior de la Iglesia si las mujeres teníamos alma o no....si no teníamos alma qué es lo que éramos, o sea éramos animalitos... no éramos seres humanos, no éramos personas...".

La emergencia del tema de las mujeres responde como he señalado en un inicio a las condiciones internas como externas que se generaron éstas son referidas por las entrevistadas como un reconocimiento al "cambio fundamental que vivió América Latina en el siglo XX con la emergencia de las mujeres como actor social relevante, que avanzó en derechos ciudadanos, en participación en el mundo del trabajo en la conquista de autonomía personal y familiar. Reconoce también el rol protagónico que tendrán las mujeres en el siglo XXI, como poderoso y nuevo motor del desarrollo con equidad al que aspira nuestra Región latinoamericana." Es en el siglo XX donde las mujeres alcanzan ciudadanía.

En este contexto la institucionalidad entiende que "El lenguaje es una realidad. ...en el sentido de que el lenguaje utilizado en la legislación debe evitar cualquier forma de discriminación motivada en las diferencias de sexo. Es un compromiso con nuestra historia y un compromiso con la comunidad internacional." La transformación de las relaciones de discriminación estarán impulsadas por las formas de designar, de definir al sujeto.

Desde el Estado se promueve la instalación el posicionamiento del tema, un rol importante asignado a los medios de comunicación en este proceso esta definido en uno de los objetivos 
del Plan de Igualdad e Oportunidades que señala" Promover, a través de los medios de comunicación, la incorporación en la agenda pública de las diversas realidades y aportes de las mujeres a los distintos ámbitos de la vida social, cultural y económica, respetando la diversidad de las identidades, calores y experiencias de las mujeres" (47); en este sentido se le atribuye a los medios un rol importante en la transformación de las representaciones de sujetos y por otro lado en la instalación de las temáticas de las mujeres y las diversidades de sujetos no sólo en la agenda pública sino también en la opinión pública.

La instalación pública e institucional del Plan de Igualdad de Oportunidades marca un hito importante en la consolidación del discurso y la acción respecto al tema de las mujeres, "La preocupación por los problemas de las mujeres tiene su historia en nuestro país; pero todos estaremos de acuerdo que en los últimos años han adquirido una particular relevancia en la conciencia de la ciudadanía y en el Estado...pues forma parte del corazón de su misión que es contribuir a la formación de una sociedad más justa, democrática, humana y solidaria, y que se expresa en el Proyecto de Ley que consagra la igualdad de hombres y mujeres." La temática de la igualdad se instala estrechamente asociada a los procesos democráticos, al reconocimiento de los derechos de los sujetos sociales y en la transformación de sus estructuras y legislación. Con la institucionalización del SERNAM no sólo se instala públicamente la preocupación y la acción respecto al tema de las mujeres, sino también el Servicio Nacional de la Mujer, que nació como un compromiso con la profundización de la democracia, con la no discriminación de la mujer y con la igualdad de oportunidades", instala el concepto de igualdad como aspiración compartida para las mujeres.

El proceso de apertura del sistema político, social nacional, potenciado por los acuerdos y organizaciones internacionales permiten en los noventa, incorporar en la estructura y en los discursos de la estructura y el gobierno a nuevos sujetos y demandas. Sin embargo este proceso de apertura, presenta sus resistencias, en los núcleo más duro del aparato público, lo que se traduce no sólo en la instalación de una estructura, en los discursos, en las agendas y prioridades del gobierno, sino significa un reconocimiento de las temática como un tema vinculado a la eficiencia del sistema económico social del país. La temática de las mujeres se incluye en las decisiones no sólo desde una perspectiva social, sino también económica.

Desde el habla de las entrevistadas se requiere además un proceso paralelo de instalación de la temática no sólo estructural, sino también comunicacional de manera de impactar hacia un cambio en las sensibilidades y representaciones de quienes toman decisiones a nivel gubernamental, “...el Estado tampoco asume per se el tema de la igualdad de oportunidades, porque resulta que Perico Pérez que es el Ministro de tal cual encuentra que esto no tiene ninguna importancia y que las mujeres están pataleando por las puras..."

Un aporte importante en la instalación y reconocimiento de las mujeres fue la elaboración e implementación del Plan de Igualdad de Oportunidades de las Mujeres, que regula el período 1994-1999, este se basa en el concepto de igualdad como ideario constitutivo de la democracia, un primer paso que se plantea en el desarrollo y aplicación de cambios constitucionales, en donde señala que "deben contemplarse normas que, en los distintos niveles, no se limiten sólo a establecer propósitos de igualdad, sino que operen como efectivos instrumentos de cambio, ya sea en la vía de la prevención y sanción de situaciones de discriminación, de la eliminación e obstáculos para la efectiva libertad e igualdad de las personas o de estímulo a conductas igualitarias" (48). La elaboración de cambios normativos, de acuerdo a lo señalado en el 
documento pretende impactar no sólo a cambios estructurales sino también culturales, que se traduzcan en la conducta cotidiana inclusiva de los sujetos.

\section{Situación de las mujeres}

Las diferencias en el reconocimiento de las mujeres como sujetos sociales, transversaliza la sociedad, y al Estado. El camino llevado por las mujeres para ser reconocidas como interlocutor, se traduce en la lucha por los derechos y reivindicaciones en los ochenta y por las aperturas necesarias en la estructura social, política jurídica y estatal en los noventa.

Las mujeres están ocultas en las estadísticas de pobreza, o en las interpretaciones que se realizan sobre los datos. En los ochenta, la lógica de la pobreza y de la represión no permiten establecer distinciones diferenciadoras, que promuevan demanda social desde las mujeres.

Las mujeres son vistas desde su dependencia a otro, al marido, la pareja, lo padres, se entiende y describe a las mujeres dependiendo de otros social y simbólicamente, "...las mujeres le debían obediencia al marido.”. En ese contexto no existe legislación que permita proteger ni resguardar los derechos de las mujeres, no cuentan con derechos propios.

Sin embargo, la movilización social, no sólo permitió instalar la demanda social durante la dictadura, sino también posicionar en ciertos sectores, principalmente ONG's, universidades y centros de investigación, temáticas relativas a las mujeres.

Las distinciones de las mujeres y las nuevas representaciones de ellas permitieron, generar procesos de inclusión de estas en la estructura. La estructura, le reconoce en sus diferencias, desde allí también reconoce que las mujeres son sujetos que presentan realidades y necesidades particulares las que no son construidas al alero de otro.

Se reconoce que las investigaciones y estudios elaborados abren procesos de inclusión. La situación de violencia como he detallado en puntos anteriores viene, luego del diagnóstico que hace público el tema, a poner la temática de la violencia desde la necesidad de ser tratado como un tema que no sólo afecta a las mujeres, en el ámbito familiar, sino como "fenómeno se produce en todos los estratos socioeconómicos, y está evidencia plantea la urgencia de tratarlo como problema social objeto de políticas sociales", desde la incorporación de la temática en el primer Plan de lgualdades, se considera el tema de la violencia contra las mujeres como un tema que no sólo involucra a algunas familias (49).

A fines de la década el reconocimiento de las mujeres, incorpora una nueva distinción un cuestionamiento, "... las mujeres no pueden ser vistas desde su marginalidad, sino que deben ser vistas desde su potencialidad, y eso de alguna u otra manera cambia el concepto de cómo llega a las mujeres". No sólo basta un reconocimiento, la visibilización de éstas sino se requiere cuestionar desde donde se establecen las distinciones, si estas son elaboradas desde la carencia, desde la vulnerabilidad se parte de una distinción discapacitante, que impide la individuación de los sujetos.

\section{Asociado a procesos de discriminación}

Es importante destacar que los procesos de exclusión identificados por los y las hacedoras de políticas sociales, indican que la situación de las mujeres comienza a ser valorada en la medida que se establecen distinciones y comunicaciones respecto a los costos económicos más que en los costos sociales que conllevan la discriminación. 
La valoración de la violencia contra las mujeres, por ejemplo, como problema social, toma valor en la medida en que la temática cobra un giro, es decir, la problemática no sólo es traducida en términos sociales y culturales, sino también en términos de costo-eficiencia económicos. Este es un nuevo parámetro sobre el cual se sustenta la evaluación de la exclusión, en la medida en que su traducción se plantea desde una evaluación económica del impacto que esta conlleva. Las mujeres son incluidas a partir de las distinciones que realiza el sistema económico.

Lo anterior es reforzado en la medida que los organismos internacionales, los bancos mundiales no sólo desde el ámbito social, cultural, sino también económico, establecen prioridades, enfoques y obligaciones que incorporan la temática de las diferencias. Establecen nuevas comunicaciones que se refieren a las diferencias y la inclusión de éstas, la "visibilidad pública ha llegado a ser de tal importancia social, económica y cultural, que hace imposible ignorar sus demandas."

A fines de los noventa es posible afirmar que las mujeres y la sociedad en general tienen mayor conciencia de la discriminación (50), esta es incorporada en las distinciones a través de las cuales las mujeres se refieren a si mismas, "yo creo que cada vez es más difícil que una mujer te diga que no son discriminadas" y el reconocimiento de esta por la sociedad y la estructura.

La discriminación esta vinculada a la construcción de estereotipos y a la reproducción de éstos. El que la sociedad se refiera a los sujetos discriminados da cuenta de mecanismos que operan para mantener la inclusión de los sujetos al sistema, aquellos que no den cuenta de la discriminación serán excluidos de las conversaciones por lo "...que hay una discriminación muy solapada ahora es políticamente correcto hablar del tema de la mujer porque está como de moda desde los organismos internacionales, pero que sin embargo persisten".

Los medios de comunicación, estructuran, refuerzan y elaboran distinciones, imágenes. Crean imagen y crean realidades, serán estos quienes permitan o dificulten determinados procesos de cambio cultural. Es decir, para los las hacedoras de políticas sociales, los medios de comunicación potenciarán, dificultarán o reproducirán los procesos de inclusión/ exclusión en la medida que estos contribuyen a cambiar o reforzar las imágenes que tenemos; por ejemplo de los roles que hombres y mujeres debemos realizar en nuestra sociedad.

Desde el reconocimiento del importante papel de los sistemas de información, de comunicación, la institucionalidad, se han planteando la necesidad de trabajar con ellos de modo de permitir, de crear imágenes nuevas de mujeres, desde donde las mujeres puedan reconstruir, redefinir las imágenes de si mismas, sus identidades. En este sentido las imágenes de mujeres permitirán la inclusión o exclusión de éstas en determinados campos sociales, las que potenciaran o dificultarán los procesos.

La inclusión de las mujeres está revestidas de dificultades en el ejercicio de nuevos roles y la incorporación diferenciada de éstas en nuevos campos. En ese nuevo territorio las mujeres deben establecer mecanismos para estructurar relaciones y realizar comunicaciones, “...las mujeres que tienen puestos de poder medianos necesitan saber ejercer mejor ese poder, que no lo saben tanto..."

Un elemento importante señalado a través de las entrevistas es el hecho de que las mujeres se incorporen al mercado laboral. Es la incorporación en este espacio el que le otorgaría mayor 
inclusión, en la medida que cuenta $\infty n$ dinero, desarrollo, personal y profesional, se logra autonomía.

Existe una relación entre discriminación, construcción y reproducción de estereotipos, y una serie de barreras o dificultades que se presentan para, no sólo el cambio sino la inclusión social de las mujeres, las barreras son obstáculos que no permiten el desarrollo y la incorporación real de las mujeres, "obstáculos reales para la incorporación al mundo laboral, etcétera, entonces hay muchas leyes que las favorecen ... pero el ámbito cultural, el ámbito de políticas públicas, todavía también permanece discriminada la mujer. Por ejemplo, en el tema de la salud, en el acceso a la salud privada, la mujer es obviamente discriminada en su etapa fértil, quiera o no...".

\section{Asociado a procesos sociales y culturales}

La exclusión de las mujeres no es vista, no se ven ni valoran la participación social, laboral, política y pública de éstas, "El tema por ejemplo de la desigualdad de la remuneración entre los hombres y las mujeres, la brecha salarial es enorme".

Las diferencias entre hombre y mujeres, como explicitaciones de exclusión, son asociadas a aspectos culturales y sociales que van más allá de la realidad del país y que es compartida por otros "...esto es un problema cultural y mundial que en todos los países desarrollados existe este problema, acá lo tenemos mucho mayor digamos de las desigualdades entre hombres y mujeres.."

La estructura emergente en los noventa pone, coloca, sitúa en la mesa de discusión, en lo público el tema de la mujer. Con ello en el último período de la década logra no sólo hacer una apuesta a la inclusión de las mujeres, también con ello reubica la discusión en torno a la relación hombres mujeres.

Se producen aperturas en los sistemas que permiten ampliar y re situar las relaciones y los procesos sociales de hombres y mujeres respectos de los roles históricos, lo cotidiano, los microespacios, como también una discusión respecto a los macro espacios, la transversalidad de la discusión de lo cotidiano a lo político y social.

Son las mujeres que se vuelcan sobre sus distinciones para generar un cambio en ellas. Desde el habla de las entrevistadas es posible distinguir un cuestionamiento a las distinciones que construyen o refuerzan procesos de exclusión o inclusión "...las propias mujeres tenemos instalado en nuestro archivo computacional una serie de cosas que trancan una mejor evolución: la crianza de los hijos no siempre está ordenada como debe ser, todavía hay mamás que igual de repente la hija es la que está haciendo la cama, es la que está barriendo y el cabro está jugando a la pelota en la plaza...". El esfuerzo institucional está orientado a potenciar estos cambios transversalmente para provocar una modificación en las construcciones sociales.

Sin embargo en las distinciones de las hacedoras de políticas sociales es posible observar construcciones que refuerzan los mecanismo de exclusión de las mujeres, "...todavía hay un peso de la tradición y esto no alcanza tampoco a todos los grupos sociales, el sector socioeconómico de menores ingresos es mucho más tradicional, mucho más machista, las mujeres asumen como lo normal que el hombre es buena persona, las ayuda, no lo exigen...", desde esta afirmación es posible desprender que el machismo no aparece como una construcción transversal sino más bien ligada a un grupo social, lo que redunda en las 
dificultades para observar y describir bajo categorías similares la situación de las mujeres de otros grupos sociales. En otras palabras, sabemos que la situación de discriminación no es un problema propio de cierto grupo, sino una situación que en todo el mundo tiene manifestaciones y construcciones diversas que responde a la lógica de desigualdad en las relaciones de poder entre hombres y mujeres.

Las transformaciones culturales y sociales requieren, desde lo recogido en las entrevistas, un esfuerzo que apunte a cuestionar los diversos ámbitos que reproducen prácticas de exclusión. Ejemplo de ello, es el cuestionamiento de las mujeres en las empresas, 'derribar mitos y creencias como ... que las mujeres son más caras porque tienen hijos. La media de hijos ...es un uno punto siete, o sea, en cuarenta años de vida laboral, las mujeres tienen dos hijos y además el período de embarazo lo paga la seguridad social, el único costo que tiene la empresa es el del reemplazo, entonces cuando tú empiezas a hacer visible eso, estás derribando mitos y creencias y vas instalando el tema y das verdad".

El cuestionamiento respecto de la exclusión social de las mujeres resitúa socialmente las imágenes de sujetos mujeres y hombres así como los roles y las relaciones, en lo público y privado de la vida de los sujetos, "...yo creo que seguir machacando con el cambio cultural, ... es lo único que pesa realmente... cuando en una oficina todos saben ...que no se puede ... ejercer el acoso sexual y que no sea necesario que sólo haya una ley, que no te vaya a los tribunales, sino que sepan los funcionarios y las funcionarias, ni entre hombres ni entre mujeres, o sea, yo creo que eso es básico."

Es interesante desatacar que la política implementada, las distinciones y cuestionamiento de las relaciones entre hombres y mujeres en la última década desde lo público, sin embargo requiere, desde las entrevistadas esfuerzos por cuestionar a los individuos "...necesitamos hacer cambios internos potentes y empezar a discutirlos más profundamente, o sea hay una cosa general que tiene que ver con el Estado y el gobierno, pero también hay una cosa individual, personal".

\section{Respecto de los sujetos mujeres}

Como he señalado y a modo de síntesis en los puntos anteriores, las construcciones de sujetos, están vinculados a la elaboración de estereotipos. La discriminación está asociado a procesos de inclusión/ exclusión.

Las mujeres como he señalado han sido distinguidas respecto a otro. El no reconocimiento, la invisibilización de éstas como sujetos sociales, las ha mantenido en procesos de individuación secundaria. Excluidas en la exclusión, o incluidas, por ejemplo a través de su participación en movimientos sociales y de organización social, incluidas en la exclusión.

El proceso de generación de opinión, el romper las barreras o las construcciones respecto de quienes son, que necesitan, como viven, con quienes se relacionan, sus intereses, etc. logra generar construcciones diferenciadas. El reconocimiento de estas construcciones como limitaciones y barreras para ser/ hacer/ estar, se traducen en la instalación de nuevas comunicaciones institucionales, así también entre sistemas. En un inicio esta apertura significó, una amenaza para el orden establecido. El proceso se inclusión de las mujeres es comparado con el proceso de reconocimiento políticos de las mujeres "(Las mujeres) han conquistado el derecho al sufragio...". Los logros en los avances de las acciones implementadas se cuentan como procesos de inclusión de las mujeres a la vida social. 
“...Te diría que la mujer fuera más sujeto, más incluida”, el reconocimiento de la condición de sujetos de las mujeres, genera procesos de inclusión y de construcción de identidades diversas. Los procesos de inclusión/ exclusión no son el resultado sólo de las aperturas del sistema estatal, sino social, de los diversos mecanismos privados y públicos para articular la transformación en estos procesos, "hay un común denominador: así como pedimos dignidad para la mujer en la casa, pedimos dignidad para la mujer en el trabajo. Y porque pedimos dignidad en la casa y en el trabajo, también pedimos dignidad para la mujer en su persona. Y por eso aquí, la campaña "Sonrisa de mujer", tiene que ver con lo más profundo, que es la dignidad del ser humano para sonreír, y sonreír con fuerza y con ganas." La inclusión de las mujeres se reconoce posible desde la construcción de identidad.

La incorporación de las mujeres al mundo social, se traduce en la inclusión de éstas a un mundo del cual no participaban, "cuando las mujeres nos incorporamos al mundo de la política, ése no era un espacio que estaba vacío, era un espacio que estaba lleno, estaba lleno por los hombres, y por lo tanto ha significado ir abriéndose el espacio, haciéndose el "huequito", con inteligencia, con la pelea, con la lucha, cada una lo hace de manera distinta, de acuerdo a las posibilidades que tiene,."

Desde las entrevistadas este proceso de inclusión conlleva un esfuerzo, una pelea por abrirse un espacio que aparece cerrado. Las mujeres se encuentran en el mundo cerrado de la exclusión.

Los procesos de exclusión/ inclusión son vistos no sólo desde la incorporación de las mujeres a un nuevo espacio, sino también en la posibilidad de generar aperturas genéricas. Que sitúen a mujeres y hombres en nuevos espacios, "En el tema laboral también empiezan a tomar conciencia que mal que mal si están haciendo el mismo trabajo deben... y se empieza a tomar crecientemente conciencia que el compartir la vida laboral y familiar es un tema que no pueden ellas seguir asumiéndolo todo, desde que lo empiezan a ayudar un poco entre comillas, hasta decir oye compartamos un poco...". Se propone resituar los procesos de inclusión de manera de ver estos transversalmente y a la vez incorporando no sólo a mujeres sino también a los hombres.

En otras palabras en la medida que ambos ocupan diversos espacios sociales, públicos y privados se provoca una reestructuración de las relaciones, "...compartir lo privado realmente así como está la mujer compartiendo lo público, entonces ahí ha habido una evolución, pero una evolución por las jóvenes y jóvenes que están presionando por nuevos sistemas de vida, que se comparte mucho más"

Finalmente quisiera detenerme en la necesidad de autonomía de las mujeres. Desde una visión crítica, las entrevistadas señalan la necesidad de profundizar en los mecanismos de autonomía de las mujeres "yo creo que las mujeres necesitan trabajar, porque como las familias se han diversificado las mujeres necesitan ser autónomas, y para eso necesitan que el Estado se preocupe y les de las garantías de poder dejar a sus hijos y poder acceder al mundo del trabajo, y que además se les paguen los mismos sueldos...". Se requiere garantizar las condiciones que permitan la apertura e inclusión de las mujeres en los espacios laborales.

La inclusión de las mujeres no sólo pasa por el acceso de ellas al mundo laboral, sino también a condiciones salariales que les permitan la autonomía, lo que se asocia al ejercicio de los derechos "...una mujer que no tiene platita en el bolsillo es una mujer que está disminuida la pongas donde la pongas y con los derechos que tenga así como en las leyes, si no 
tiene platita en el bolsillo va a estar siempre excluida, siempre se va a sentir discriminada.". La autonomía, la no dependencia de las mujeres de otro permiten la inclusión y la posibilidad de ésta de generar procesos de individualización.

Otro aspecto ligado a la autonomía es la emergencia del concepto de autodeterminación de las mujeres. La comprensión de las diversas necesidades y características permiten señalar que se requiere garantizar la inclusión social de las mujeres, y al mismo tiempo garantizar el respeto a la determinación de sus propias vidas, "que la mujer sea autodeterminante de sus derechos sociales, culturales, reproductivos, sexuales...", a garantizar el respeto y el derecho a las decisiones de éstas sobre si mismas.

\section{Análisis FONADIS}

A continuación me permito presentar el análisis de la información recogida en la estructura del Fondo Nacional para la Discapacidad. FONADIS. Para la presentación de los hallazgos he realizado un cuadro resumen por cada punto correspondiente a los objetivos específicos planteados. A continuación de cada cuadro presento un breve resumen de este para luego continuar con el detalle de la información y análisis de las categorías identificadas.

(i) Representaciones a través de las cuales las estructuras estatales dan cuenta de los sujetos hacia los que orientan sus políticas sociales. (qué sujetos)

Tabla resumen:

\begin{tabular}{|l|l|l|}
\hline \multicolumn{1}{|c|}{$\begin{array}{c}\text { REPRESENTACIÓN } \\
\text { ligada a }\end{array}$} & \multicolumn{1}{|c|}{ AYER } & \multicolumn{1}{c|}{ HOY } \\
\hline Diferencia & $\begin{array}{l}\text { Minusvalía - lo medico } \\
\text { Carencia- falta de. } \\
\text { Anormalidad- enfermedad } \\
\text { Limitación }\end{array}$ & $\begin{array}{l}\text { Discapacidad - lo social } \\
\text { Se integra al entorno, el } \\
\text { entorno discapacita }\end{array}$ \\
\hline $\begin{array}{l}\text { El entorno - lo social yociado al consumo } \\
\text { cultural }\end{array}$ & $\begin{array}{l}\text { Asociadreras } \\
\text { Símbolo }\end{array}$ & $\begin{array}{l}\text { Barrencias } \\
\text { Diferenos } \\
\text { Derechos }\end{array}$ \\
\hline Situación del sujeto & $\begin{array}{l}\text { Invisibilidad } \\
\text { Vergüenza } \\
\text { Ocultamiento } \\
\text { Pobreza } \\
\text { No ser - no hacer } \\
\text { No ocupa espacio social/ no } \\
\text { ocupa espacio }\end{array}$ & $\begin{array}{l}\text { Visibilidad } \\
\text { Deseos de ser } \\
\text { Personas } \\
\text { lgualdad de oportunidades } \\
\text { Ser - hacer } \\
\text { Se apropia del espacio } \\
\text { social/ ocupa espacio }\end{array}$ \\
\hline
\end{tabular}

Las categorías que contiene el cuadro resumen y que serán detalladas más adelante se refieren en términos generales a los siguientes aspectos, desde los relatos y material revisado es posible señalar que las y los hacedores elaboran distinciones que podría afirmar, se sitúan en un antes de los noventa y después de éste. Respecto de ello los sujetos con discapacidad 
en un primer momento, son básicamente distinguidos desde la discapacidad, desde la falta de una capacidad o función física que los hace distinguibles respecto del resto de las personas.

Luego en un segundo momento, marcado por el cambio político que vive el país, así como el establecimiento de un marco legal respecto de las personas con discapacidad, el discurso relativo se sitúa en torno a los sujetos, como tales y de éstos con relación a una situación de discapacidad, siendo la calidad de sujetos la que les define. Se produce un reconocimiento de los sujetos.

Lo anterior se refuerza en la idea que el entorno está definiendo la situación de los sujetos, es decir, es éste el que determina las distinciones de que se dan cuenta. En otras palabras en un primer momento las personas con discapacidad son distinguidos desde la discapacidad, es ésta la que genera un reconocimiento o ésta es distinguida socialmente. Los sujetos se transforman en símbolos, desde su condición de no sujetos, en un símbolo en la medida en que realizan esfuerzos súper - humanos para acercarse a la posibilidad de ser personas. La Teletón pone en lo público el tema de la discapacidad (51).

En la década de los noventa, la distinción se realiza desde la idea de sujeto con discapacidad. Este en un primer momento es visto, luego se distingue la limitación que presenta el sujeto en lo social. Las dificultades no provienen de su condición de discapacidad, sino más bien, esta condición, es definida desde las limitaciones que pone el entorno. La lectura que se realiza, es que el entorno es quien define desde sus posibilidades o imposibilidades la apertura para que los sujetos sean parte del entorno o del sistema social. Para reafirmas lo señalado, las distinciones se centran en las dificultades o las barreras, las dificultades que socialmente y culturalmente ponemos para no permitir el acceso, la igualdad de oportunidades a las personas como sujetos de derecho.

Los elementos señalados anteriormente, pueden observarse en las representaciones que son asociadas a los sujetos con discapacidad. Los sujetos con discapacidad no son considerados como sujetos, en la medida que no están en condiciones de ser/ hacer, es decir no se incorporan a la educación, al trabajo, espacios de integración y construcción de identidad social y cultural. Se mantienen invisibilizados, desde las familias, la sociedad, sólo sus diferencias son visibles, (éstas avergüenzan), son estigmatizadas, escondidas, no se habla de ello. A lo anterior se suma que las distinciones realizadas antes de los 90', están asociadas a la condición de pobreza, es decir se refuerza la idea de carencia, (una habilidad, condición física, mental o social), su falta se amplia más allá de su cuerpo.

El cambio se produce, desde la distinción de sujeto de derecho, por tanto visibilizado en su condición de sujeto social. Desde el reconocimiento de sus derechos, de igualdad de oportunidades, puede acceder a educación, trabajo, puede construir identidad también puede hacer. Se visibiliza, se le reconoce en su condición de desear, querer, de ocupar un espacio social. Las distinciones que los y las hacedoras de políticas sociales, realizan es que los sujetos con discapacidad son vistos, ellos pierden la vergüenza, es decir se apropian de lo publico, se les ve.

A continuación quisiera extenderme, explorar las categorías identificadas, las observaciones de las observaciones que los y las hacedoras de políticas sociales realizan respecto de los sujetos con discapacidad.

\section{Desde la representación centrada en la diferencia.}


Como he señalado en un principio la representación de los sujetos con discapacidad ha estado centrada fundamentalmente en la discapacidad, representaciones respecto de la condición de discapacidad.

Estas al centrarse en la discapacidad se refieren principalmente a las diferencias, desde la carencia, la falta de capacidad, función física que los hace dispares respecto del resto de las personas. Estas distinciones se modifican, en un segundo momento, marcado por el cambio político que vive el país, transformación producida por el establecimiento de un marco legal respecto de las personas con discapacidad, el discurso relativo se sitúa en torno a los sujetos, y de éstos con relación a una situación de discapacidad. Se produce un reconocimiento de los sujetos como tales. Ahora bien la distinción sobre la discapacidad se transforma también, la discapacidad no es constitutiva del sujeto sino más bien está definida desde el entorno, es decir, la discapacidad se relaciona con la traducción de la diferencia en lo social, como ésta inhabilita, limita, restringe, no entrega identidad a los sujetos.

Como he afirmado, en el discurso de las personas entrevistadas al referirse a una persona con discapacidad se recoge la imagen de la falta de algo, carencia. Pérdida que el otro, el que observa, identifica y produce en la distinción desde la diferencia (persona sin discapacidad), “...pensando en que ellos en estos momentos, pensando en una persona por decir alguna cosa que le falta una pierna, él no se siente enfermo, sino que le falta algo." Esta falta hace la diferencia, sitúa al sujeto en desigualdad, limita su movimiento, sus posibilidades de hacer, de ser.

Esta carencia se refiere a la situación social en que se encuentran las personas, se ubica en lo social, en el entorno, en las imposibilidades de las personas para cambiar la situación en que se encuentran, se sitúa en el acceso de éstas a tratamientos, rehabilitación o programas que permitan un cambio en las condiciones de los sujetos. El acceso como figura afirma la idea de la posibilidad de acercarse, ir hacia lo que otros tienen, es también la figura de la entrada, la no existencia de limites, la factibilidad de que la persona con discapacidad cuente con el espacio y la acción que le permitan estar "dentro de".

Otra forma de estructurar representaciones, corresponde a las imágenes que se construyen respecto de las personas con discapacidad estructuradas en comparación con otros sujetos, en contraste con aquello que es definido como lo normal, lo que no presenta limitaciones (52). La discapacidad entendida como la capacidad dferenciada, desde la percepción de las/ los hacedores de políticas sociales las personas con discapacidad se identifican en el reconocimiento de una capacidad diferenciada, se reconoce que es la resolución social de ésta la que anula.

Quisiera volver sobre la idea de la limitación. La limitación construida desde lo social, desde donde se define la normalidad. Es decir, la limitación física que determina a una persona al uso de una silla de ruedas, "la silla de ruedas, esa es la discapacidad", en este ejemplo se percibe la ayuda técnica, la silla de rueda, es la persona, se constituye en la representación del impacto que significa para el que observa, el modo más evidente de hacer explícita la falta. Lo que limita es la evidencia desde la percepción de los otros, es la percepción, la distinción de la discapacidad, "es lo que tú puedes ver" la persona con discapacidad se visibiliza en la medida que nos impacta "ese es como la imagen que queda todavía más fuerte del impacto con respecto a la discapacidad".

Resulta contradictoria la idea de que aquel sujeto que no se ve, invisibilizado por la discapacidad, estaría más integrado en la medida que es menos evidente la discapacidad, 
cuando se dice "Los ciegos están mucho más integrados, sordos, con lectura labial no te puedes dar ni cuenta tú", la integración se construiría desde la invisibilización de la discapacidad desde el entorno. En otras palabras la limitación está puesta desde la distinción que otro realiza sobre un sujeto; por tanto en la medida en que la diferencia no es evidente, no impacta, se subentiende desde allí que el sujeto con discapacidad(auditiva, verbal principalmente) estaría más integrado, su falta no es lo que lo define en una primera aproximación (lo que no implica que sea evidente en un segundo momento).

Resulta posible afirmar entonces que las personas con discapacidad son percibidas desde el impacto, percepción visual, que produce su condición o situación de discapacidad, desde allí entonces aquellas personas que presentan una discapacidad, que no es "visible" o evidente al otro permanece oculta. Estos antecedentes (53) reafirman que a pesar que la discapacidad para oír es la más recurrente en la población, la percepción de los otros es que las discapacidades físicas son las más frecuentes, lo que refuerza la idea de que éstas son las que impactan, "... hay discapacidades todavía que no se consideran tanto, la discapacidad psiquiátrica, o sea uno no lo ve en la calle puntualmente..."

La incidencia de determinadas representaciones es el reflejo del impacto que la percepción de la condición de discapacidad tiene en las personas. El valor de reconocimiento está puesto en el daño a las capacidades y a la evidencia de éste, es decir aquellas discapacidades que afectan las capacidades sensoriales son menos "valoradas" en comparación con las que presentan un daño físico, "las sensoriales y las físicas, que son las que tienen más presencia también y que son más fáciles también obviamente de consultar." Se sitúa como ya he afirmado en la visibilidad de éstas, sino lo distinguimos, no existe, "entonces van a la escuela especial, la visibilidad no es tan evidente". La condición de discapacidad ha sido ocultada, avergüenza no sólo a la familia al propio sujeto sino también al entorno, como respuesta se crean estructuras que no hacen más que ocultar, invisibilizar, redundando en la exclusión de los sujetos.

Las distinciones construidas socialmente han ido cambiando respecto no sólo de la forma de tratar o explicar las discapacidades sino también en los modos de referirse a ellas en lo cotidiano, esto se observa en la valoración que los calificativos contienen "Cuando... al menos cuando yo era chico, (...) uno hablaba de cojito, cieguitos, curcunchos, manquitos...". Las distinciones sobre la discapacidad es la que sigue construyendo distinciones.

Los cambios en las distinciones también han contenido los modos de categorizar a los sujetos, elaborando distinciones que dan cuenta de los énfasis sobre los que se construyen “... del lisiado, pasamos al minusválido y del minusválido pasamos al discapacitado. $Y$ ya, digamos, etimológicamente hay un cambio en la conceptualización de la persona ¿ya?. La evolución de las distinciones, van desde el centrarse en la "imperfección orgánica", luego en la determinación de una menor valía en lo social, para luego centrar las distinciones sobre las personas. "Incluso muy centrada en la preocupación de lo peyorativo que pueden ser los adjetivos para calificarlos, ...por ejemplo, cuando se decía lisiado se hablaba porque la máxima visibilidad que había de personas era por el tema físico y la silla de ruedas, lo cual Teletón en este país en eso se ha enfocado", es importante destacar una vez más que la Teletón a través de sus modos de operar ha instalado distinciones.

A partir del material recopilado se identifica que el sistema de salud y educación quienes de alguna manera se "hacen cargo" o a quienes se les asocia la temática "... antes el que era discapacitado era enfermo ¿ya? Y no se salía de ahí." a través de la creación de espacios, en los cuales se institucionaliza o trata a las personas en sus diversas discapacidades, ejemplo 
de ello son los hospitales psiquiátricos, las escuelas especiales, a ellos se suman las organizaciones de padres o familiares quienes se agrupan para resolver de manera solidaria el tratamiento de la problemática que afecta a sus familiares "...se asociaban para crear ciertas instituciones para ellos mismos, qué sé yo, el COANIL para tratar a los niños limitados cierto y otros grupos que se crearon fue por cosas bien específicas."

A través de estas concepciones se reconoce que a la persona con discapacidad, se le hacía sentir anormal, enfermo, se centra la problemática en alteración en la salud de la persona, hacían sentir enfermo, no es que la persona con discapacidad quien elabora distinciones sobre si mismo desde la discapacidad - enfermedad, sino es el entorno el que sostiene estas distinciones, "Antes se sentía... lo hacían sentir enfermo, él era un enfermo que no podía trabajar, que no podía hacer esto y no podía hacer esto." La enfermedad, está puesta en el no hacer, la imposibilidad de poder hacer.

La condición de enfermedad los deja fuera, se refuerza esta exclusión a través de crear espacios que confinen e invisibilicen a las personas y sus problemáticas, se les encierra, pierden derechos, “.... antiguamente en todo el ámbito de la discapacidad... por eso decíamos que era un poco médico, (...) había que internarlos, sacarlos de la casa, dejarlos internados en alguna parte y de repente ir a verlos qué sé yo, pero eran enfermos." La imagen de relegar, confinar esta asociado a la idea de enfermedad, de proteger a los otros no discapacitados.

Se institucionaliza, "La historia ha dicho...que la persona con discapacidad era una persona que estaba mu como escondida, se trataba en forma muy asistencial...". La asistencialidad, darle al otro lo que yo desde una condición de superioridad identifico como necesidades relevantes.

Las acciones asistenciales, refuerzan relaciones de dependencia, redundando en la sobreprotección, exclusión de las personas, "las generaciones anteriores de discapacitados tienen la actitud, digamos, más pasiva, ya, producto de que están también incluso más avanzados en la edad y producto de que están mucho más frustrados..."

Posteriormente el concepto de "minusválido", persona que vale menos que otro, que es básicamente la noción europea. Y es bastante peyorativo, digamos, se supera el tema de hablar de lisiado y de pensar de que sólo las personas que andan en silla de ruedas tienen problemas, por lo menos el mensaje del concepto, dejando afuera a los ciegos, los sordos, no es cierto, todos los deficientes mentales, etcétera. Ya la condición de minusvalía los integra, pero en una condición de menor valor (...) a través de la incorporación de éste concepto intenta una reflexión más cercana al reconocimiento de las dificultades desde lo social asociadas a la discapacidad.

Finalmente se avanza hacia el concepto de "discapacidad", es decir, ya no sólo interesa la deficiencia o patología, sino que interesa cómo esa deficiencia, limitación, está en un contexto.

Representaciones ligadas a lo social y cultural.

Las personas con discapacidad han sido situadas en ámbitos de invisibilidad como ya he señalado y también se les ha instalado como iconos, ubicándolos en relación a virtudes especiales o diferentes que los convierten en no sujetos, o sujetos no humanos en la medida que son símbolos "Por un lado es niño símbolo y por otro es que se sobre pone a todas las limitaciones que ha tenido y se convierte en Tarzán..." . Me parece importante destacar 
que las distinciones construidas por la Teletón lejos de instalar en lo público el tema de la discapacidad, refuerzan la idea de la diferencia, en cuanto las personas generan esfuerzos supra-humanos para sobreponerse a sus limitaciones, se tiende a la normalidad. En síntesis se re centra la distinción en la diferencia respecto al otro.

Esto se ve reforzado con creencias, mitos que se elaboran en torno a las personas con discapacidad. Ejemplo de ello es que a la hora de incorporarles a espacios laborales, se les exige sobre parámetros diferenciadores, se sostiene la idea que los sujetos con discapacidad podrán trabajar o rendir más que el resto, o bien que requieren de mayor supervisión que el resto, etc. Los mitos y percepciones son reafirmadas a través del uso abusivo de determinadas imágenes, que instalan una vez, desde lo visual, como único mecanismo de conocimiento del mundo y del otro.

Las estrategias utilizadas por los medios de comunicación, para sensibilizar en torno al tema de la discapacidad han recurrido principalmente a imágenes de personas con discapacidad física, mental, niños/ as con síndrome de Down, "se ha abusado visualmente de algunas discapacidades, lo que implica por supuesto ser invisibles a otras, pero si uno lo piensa, tampoco hay una voluntad técnica de privilegiar una u otra discapacidad, más bien de aprovechar todos los elementos de discurso para poner el tema en el plano." La instalación y uso de imágenes sitúa a determinados sujetos a costas de ser (hacer) invisibles a otros. Se plantea que las acciones desarrolladas no han tenido la intención de relevar una discapacidad sobre otra, se han desarrollado estrategias diversas para situar a las personas y difundir la situación de éstas de acuerdo a las diferentes discapacidades “...entonces en esos términos no importaría tanto cuál es la discapacidad que se privilegia sobre otra. Cuando en términos de difusión también hay acciones para todas las discapacidades incluso personas sordas..."

Para reafirmar lo anterior, en las revistas "Atrévete" (54), es posible constatar el uso abusivo de imágenes de personas con discapacidad principalmente física y mental, "....el uso del Down es intensivo como icono fotográfico, por cierto" y de niños/ as principalmente, lo que instala desde lo visual a determinados grupos.

A partir de las distinciones recogidas se señala que las personas con discapacidad desde las distinciones que pesan sobre ellos, hacen uso de su condición de discapacidad con un propósito más bien utilitario, para obtener beneficio, sin embargo este uso de la relación de desigualdad estaría en proceso de cambio "yo creo que se les ha olvidado un poco, han cambiado un poco, pero también lo que decía yo al comienzo, en todos los ámbitos y en todos los niveles de personas que uno conoce: profesionales, no profesionales, qué sé yo, de alguna manera tratan de sacar provecho de su situación.". La condición desventajosa les permite en el contexto de la desigualdad, obtener beneficio.

Para los hacedores de políticas sociales la discapacidad es la imposibilidad social de integración, las limitaciones no surgen desde ellos, sino más bien desde el entorno en la medida que plantea barreras al desarrollo, reconocimiento y ejercicio de derechos.

\section{Respecto de la situación de los sujetos.}

Como ya he señalado la situación de los sujetos con discapacidad es representada desde la carencia, lo que marca el limite entre lo visible/ invisible. Esto asociado a la idea de ocultar de no mostrar, crear espacios que ocultan la discapacidad circunscrita a lo privado, a la familia, en la vergüenza del sujeto. 
También me he detenido en la representación del sujeto con discapacidad, representación que refuerza la imagen de un sujeto que no se tiene, no tiene propiedad de si mismo. Por el contrario éste es más bien propiedad de otros. En contraposición, emerge la idea, la representación de los sujetos con discapacidad, pierden la vergüenza, rompen las barreras, las dificultades que se levantan desde el entorno.

Las personas con discapacidades son reconocidos en que tienen deseos de ser, es decir a acceder, en su propia motivación para constituirse en sujetos “...son personas que (...) además tienen deseos de ser reconocidos, tienen deseos de incorporarse y tienen deseos de participar igual que el resto en todas las actividades, pero (...) son un poco a lo mejor todavía... cómo se dice la palabra... que a uno también le pasa de repente... no confían plenamente en sus capacidades todavía. (...) creo que ya no se sienten rechazados, creo que no, que ha pasado felizmente esa connotación que ellos mismos se daban antes, de ser estigmatizados, de ser rechazados por la sociedad". No es menor destacar que sería también resorte de ellos el cambio en las distinciones que el entorno construye sobre ellos.

Las distinciones construidas sobre la condición física, refuerza la condición de desigualdad, los hacedores de políticas sociales, intentan a fines de los noventa un reconocimiento de la capacidad del sujeto para representar a las personas con discapacidad desde su condición de representante de si mismo, esa persona también es sujeto actor, se representa en su calidad de persona “...yo no puedo hacer una distinción paternalista por sólo su condición, es decir, ... esa persona también es sujeto actor de su destino... la deficiencia no lo limita en lo intelectual, no lo limita ya, si es física, no lo limita en lo intelectual”.

Cabe destacar que las representaciones respecto a la discapacidad, varían determinadas por el contexto en que se adquirió la discapacidad. Desde los hacedores las personas que queda discapacitado en el fin de semana presentaría características diferenciadoras, atribuidas a su condición normalidad anterior y que es rota externamente, “(...) ha estado facilitado con un cambio generacional, los discapacitados jóvenes de hoy, el que queda discapacitado en el fin de semana, producto de un carrete, ya, tiene mucho más fuerza producto de su condición, o sea, la semana pasada yo era normal, hoy día quedo en esta condición, y la semana pasada era ejecutivo, hoy día no me puedo quedar... no me puedo echar a morir y esperar a que venga alguien a resolverme los problemas, tienen una actitud mucho más cuerda." Se entiende que las personas intentarían mantener un marco de autonomía y de no asumir relaciones de dependencia, desde el entorno habría una re construcción diferenciada de la idea de discapacidad, estas personas no pierden la condición de sujeto, sólo deben reconstruir su identidad.

Desde esta afirmación la normalidad sería más bien una condición, que es posible perder, en cuanto aumentan los riesgos en la vida urbana/ rural y la vulnerabilidad de las personas “...el grupo etáreo joven hoy día es tremendamente un grupo de alto riesgo, producto de los accidentes de tránsito, en moto.. ¿ya? La zona urbana ....o sea las complicaciones de la vida urbana generan mayores riesgos para desarrollar enfermedades que pueden dejar a una persona en condición de discapacidad: el estrés laboral que se vive en la zona urbana, el estrés acústico, digamos, los shock acústicos, junto con los de tránsito son condiciones bastante desfavorables. Y en la rural también: la escasa prevención de riesgos, digamos, ya sea en la agricultura, en la pesticida, en la minería, ya, eso es tremendamente importante considerarlo para darle este carácter al tema discapacidad, un carácter prioritario dentro del país, dentro del desarrollo del país." 
El riesgo es lo que pone en lo público y sitúa la discapacidad como un tema compartido sujeto/ entorno "o sea... tú lo ves en las noticias la cantidad... todos los accidentes, eso significa aumento de la población de personas con discapacidad: se cae la cornisa en Valparaíso, le cae a.... muere gente y los otros quedan... significa posibles personas con discapacidad, atropellos, carretes en la noche, etc."

Como ya he señalado las distinciones se realizan desde la relación con la falta, la diferencia, la contraposición que marca limites y define desde ello, identidades. Otro elemento que surge en el habla de las personas entrevistadas dice relación con que las personas con discapacidad son definidas desde percepciones que establecen limites relacionales entre la institución, a través de los proyectos y los sujetos, es decir a través de as distinciones que se elaboran para elaborar el acceso. "...no hay una característica así: este es el grupo como más característico, sino que se relaciona más que nada con los temas de proyecto, o las líneas de acción que nosotros abordamos, más que un grupo específico." Estas líneas de acción reflejan en si mismas las distinciones que se realizan desde los y las hacedoras de políticas sociales. Es decir, si observamos los proyectos que se han abierto desde la institucionalidad, a inicios de los noventa, es posible establecer diferencias en las distinciones; en un inicio las acciones se centraron en abrir espacios, recursos orientados al acceso de los sujetos con discapacidad a ayudas técnicas, atención, centrado en lo médico, en la carencia, en la entrega de posibilidades en la medida que se iguala al sujeto con discapacidad, se le normaliza. El cambio es observable en el proceso de definición y apertura del sistema a distinciones que incorporan por ejemplo, acciones orientadas al cambio cultural, al empoderamiento de los sujetos, las agrupaciones, el que éstos se visibilicen, ocupen espacio público. Además el sistema se abre, distingue la discapacidad como un riesgo posible de afectar tanto a personas mayores a jóvenes, a trabajadores, etc, es decir, como una posibilidad un riesgo al cual se expone al sujeto sin discapacidad, que lo vulnera en su condición de sujeto e identidad.

Los hacedores/ as de políticas sociales identifican a las asociaciones o agrupaciones asociadas a la discapacidad desde el proceso de posicionamiento y modo de construir la discapacidad, “...evolución que tiene el mundo asociativo... los dirigentes algunos se pueden diferenciar porque son sólo crítica, algunos que son más propositivos, más cercanos a trabajar en conjunto con las instituciones, otros más lejanos, ... pero eso depende también de marcos o de epistemologías propias de las instituciones..." La forma en que se conoce y construye la discapacidad establece el modo de construcción de la organización.

Las organizaciones son vistas desde la posibilidad de definirse como cuerpo social. Puedo afirmar, que son distinguidas en la potencialidad de apropiarse de los espacios, la agrupación se hace, es decir se sitúa como sujeto social, en sujeto de derechos en la medida en que es consciente de ello, se apropia del hacer, para ser; "en este momento, la agrupación se hace principalmente ...desde el punto de vista político porque de repente... es un grupo importante de gente...". Como sucede a las personas con discapacidad, las organizaciones son parte del entorno en la medida que son distinguidos por el.

El espacio social, así como el espacio particular, esta definido desde el movimiento de la voluntad orientado hacia algo, al deseo de participar, de sentirse y de hacer, estos elementos entregan identidad social también individual, “... tal vez lo que más los caracteriza es ese deseo de participar, de sentirse y de hacer a la gente hacerlos sentirse parte de la sociedad en general. Les gusta mucho sentirse reconocidos, apoyados, por los otros...". Esto se reproduciría en lo social, en la interacción que le devuelve al otro su calidad. 
Esta apropiación no sólo pasa por los espacios sociales, del conocimiento de si mismos, de la condición propia. "...muchos colectivos piensan que el hecho de tener la discapacidad van a saber de mejor forma cómo trabajarla, qué necesidad hay...”. Esta distinción pone de manifiesto el que la condición de discapacidad, no implica (para las/ los hacedores de políticas sociales) conciencia respecto a la discapacidad y la multiplicidad de factores asociadas a la condición de los sujetos. Es decir, en la medida que los colectivos han reproducido las distinciones y representaciones de los sujetos con discapacidad en sus propios espacios, estos al igual que el entorno, deben trabajar para un reconocimiento de estas construcciones de modo de construir una alternativa que no reproduzca la exclusión, o la exclusión en la inclusión.

La visibilidad es elemento que define la demarcación entre lo que podrá estar dentro o fuera del sistema. El limite de la inclusión en la exclusión. La frontera se establece desde las diferencias. Esta exclusión es apropiada (o no) por las personas con discapacidad, me explico, se rompe la no presencia a través de la presencia que es hecha suya, apropiada. En otras palabras las personas con discapacidad hacen de ellos un lugar que no les pertenece. Por medio de la participación toman los espacios que no les pertenecen, o son utilizados por los otros, "entonces eso sí yo creo que hay en ese sentido visibilidad social o cultural, las personas se empiezan a ver más porque se empiezan por así decirlo a apropiarse de los espacios, de los espacios... por así decirlo del espacio urbano, ahora uno los ve más en la calle, ahora que estamos en el centro a mí por ejemplo me sigue Ilamando la atención la cantidad de personas en silla de ruedas que circula...". Se produce un acto paradójico, las personas con discapacidad, son vistas, desde la discapacidad, son visibles en la medida que ocupan espacios, a pesar de sus discapacidad, espacios que son referidos a otros, espacios públicos, que los sitúan en una relación diferente.

El proceso de delinear al otro va evolucionando, después cambia la cosa, en la medida que se incorporan otras observaciones, otras distinciones desde las relaciones y comunicaciones que se establecen "Después cambia la cosa, el discapacitado no es solamente enfermo, sino que hay tiene otras... hay otro aspecto también que lo discapacita, entonces hay que tratarlos en forma más global, multiprofesional, multidisciplinario..." En otras palabras el habla de los/ las hacedores de políticas sociales da cuenta de que las distinciones acerca de las personas con discapacidad son elaboradas en un proceso de apertura, desde donde se valora la necesidad de establecer otras distinciones, que permitan ver, intentar dejar fuera la fragmentación, a través de ésta renuncia volver a integrar en un sujeto

(ii) Elementos a través de los cuales las estructuras estatales resignifican a los sujetos emergentes. (cómo)

Tabla resumen:

\begin{tabular}{|l|l|l|}
\hline PROCESOS & ESTADO & SOCIEDAD \\
\hline Antes de Ios noventa & No asume- no sabe & Teletón: golpea - vende \\
& No sujeto - no política social & Sujeto/objeto de caridad \\
\hline Inicio de los Noventa & Estado asume: saca a la & Sociedad global- levanta una \\
& reaz/visibiliza & realidad. \\
& Elabora marco legal & Tema internacional puesto \\
& Elabora marco institucional & en la agenda mundial. Pone \\
& Instala un tema/trabaja & parámetro. \\
& política social & Prioridad/abre al entorno \\
& Prioridad/focaliza & Familia/sujeto pierde temor a \\
\hline
\end{tabular}




\begin{tabular}{|c|c|c|}
\hline & Sujeto de derecho & lo público \\
\hline \begin{tabular}{|l|} 
Fines de los Noventa \\
\end{tabular} & $\begin{array}{l}\text { Sensibilizar- estructura del } \\
\text { Estado } \\
\text { Traslada el tema /estrategias } \\
\text { diferenciadas para la } \\
\text { inclusión }\end{array}$ & $\begin{array}{l}\text { Tema de la discapacidad: } \\
\text { traslado al campo de la } \\
\text { igualdad de oportunidades } \\
\text { Tema de todos: } \\
\text { intersectorialidad/trabajo } \\
\text { conjunto. Traspaso a otros } \\
\text { actores. } \\
\text { Cambio cultural }\end{array}$ \\
\hline
\end{tabular}

A continuación me referiré sintéticamente para luego desarrollar cada uno de los elementos que están presentes en los procesos a través de los cuales los/ las hacedoras de políticas sociales han construido representaciones de los sujetos con discapacidad. Para ello me referiré en un primer momento a algunos elementos que aparecen en el habla de éstos y que se refieren al proceso de construcción de representaciones de sujetos con discapacidad, anterior a la década de los noventa.

La década de los ochenta marca de alguna manera el proceso tanto dentro del Estado como en el ámbito social, respecto de la temática de la discapacidad. Un elemento importante es que el Estado no asume, no reconoce a los sujetos con discapacidad, lo que se traduce en la no existencia de políticas sociales dirigidas a éstos, ni a un reconocimiento ni preocupación en torno a ello. Es la sociedad, quien a través de la caridad y al levantamiento y mantención de estructuras privadas de caridad o filantropía se hace cargo del tema. Las agrupaciones de familiares, padres, pacientes, asumen desde su propia posición estructuras que permitan abordar la temática. Los sujetos son objeto de caridad y de ayuda de acuerdo a las posibilidades que éstas abren. En los ochenta, la Teletón, amplía este concepto, elaborando una estrategia de choque, asociando un determinado grupo de sujetos con discapacidad a la caridad ampliada a través del consumo de bienes que se traducen en un "aporte indirecto". El Estado ha apoyado principalmente instancias cerradas de acogida a la discapacidad a través de educación y salud, validando espacios de segregación como acogida.

Posteriormente, en la década de los noventa la temática de la discapacidad es reconocida, como elemento de cambio ha sido la democratización de las relaciones al interior del país lo que implicó un reconocimiento de la diversidad existente. A lo anterior se suman la realidad mundial, que obliga al reconocimiento a través de la firma de convenios y acuerdos internacionales respecto del tema. Puedo afirmar que la sociedad se abre, las personas con discapacidad "ocupan espacio" se apropian del espacio social.

Otro elemento es la apertura del Estado quien para estructurar la política social, se abre, focalizando sobre lo que llama grupos vulnerables. La sociedad como he señalado de alguna manera distingue y se abre a las diferencias, la demanda social se diversifica, en cuanto ésta estaba contenida en la demanda de retorno a la democracia. Ahora bien, la política en un inicio desde los aspectos destacados por los entrevistados/ as, está centrada en compensar aspectos técnicos que favorezcan el acceso de los sujetos con discapacidad a tratamientos o ayudas técnicas específicas, así como a la cuantificación de la realidad chilena respeto del tema.

A partir de las entrevistas se destaca que las representaciones cambian lo que se traduce en una transformación en la orientación de la política, se identifica la necesidad de un cambio cultural, un cambio relacional. Para ello establece estrategias de conocimiento orientado a elementos más bien subjetivos de la cultura de la discapacidad, así como a un análisis de ella 
en relación a los sujetos sin discapacidad. Desde allí establece la necesidad de sensibilizar a la población, a la propia estructura del Estado de modo de incorporar la realidad de la discapacidad transversalmente en la política social. Por su parte las familias, los sujetos con discapacidad ocupan, se apropian de espacios sociales, salen al mundo.

Si bien el tema de la discapacidad afines de los noventa, aparece perdiendo fuerza en la prioridad asignada en un primer momento, el tema se mantiene a fines de la década, se produce un proceso de redefinición de la inserción e inclusión social como elemento que permite una resignificación de los sujetos.

A continuación, desarrollaré las reflexiones señaladas, respecto del proceso de construcción a partir de los elementos que permiten una resignificación desde las estructuras estatales, de los sujetos con discapacidad,. Como he indicado anteriormente existe y se reconoce una relación estrecha, de aperturas desde el Estado y desde la sociedad, lo que aparece en los procesos de representación.

\section{Antes de los noventa.}

En un inicio di cuenta de las imágenes por medio de las cuales las personas hacedoras de políticas sociales representan a los sujetos, personas con discapacidad. Para ello se detallaron los aspectos relevantes desde sus propias observaciones, observaciones de los hacedores de políticas sociales de los sujetos, las caracterizaciones y la evolución o la historia asociada a la construcción de imágenes de las personas con discapacidad.

Ahora bien quisiera observar las observaciones de los elementos que los hacedores de políticas sociales identifican como relevantes y que forman parte del proceso de resignificación de los sujetos.

Resulta importante destacar que los sujetos como vimos en una primera parte son observados desde la carencia, se define como enfermedad, desde allí el proceso de reconocimiento desde el Estado estará más bien, destinado a acoger este aspecto y con ello se establecerá infraestructura y programas orientados a ello (55).

Es importante señalar que la evidencia de la presencia de las personas con discapacidad en Latinoamérica, en la región ha sido producto de una instalación reciente de la década de los noventa, basada en propuestas muchas de ellas, originadas y desarrolladas por los organismos internacionales: "así como nos obligan de alguna manera a tener una política económica, nos obligan a tener una política social que incorporamos ahí, nos guste de repente o no nos guste... y se trabaja de esa manera, entonces uno empieza a adoptar algunas propuestas de países que de alguna manera financian este proceso y se incorporó por eso yo creo, más que por una cuestión muy, muy absolutamente técnica" es decir desde lo técnico y financiero se presiona para la instalación del tema de la discapacidad en Chile, desde la relación que se abre con otros países, el Estado, se abre a otras distinciones. Estas nuevas distinciones pueden o no estar acompañadas de procesos internos, desde el Estado o la sociedad civil.

Desde el habla de los entrevistados, esta más bien se refiere a reconocer un aporte y presión importante desde los organismos externos lo que validó o instaló en lo nacional la temática.

Respecto del tema de la discapacidad, la Teletón antes de los noventa acogía el tema más visible, la discapacidad física, centrada fundamentalmente en los y las niñas; se elabora una 
estructura privada que se encarga del tema en la medida que esta población podría afirmar, se encuentra en mejores condiciones de cambio desde la falta, la carencia, la anormalidad, a la normalidad.

La relación social, que se establece desde la instalación de la Teletón, sitúa a los sujetos no discapacitados en un doble vínculo, que puede ser interpretado desde que este aporta, contribuye (comprando o depositando dinero) movido por el manejo publicitario que manipula los afectos, la culpa, el shock, la visibilidad repentina de la discapacidad, "... ese efecto Teletón, sobre todo manejado publicitariamente a la población no discapacitada, ... que yo tengo que dar un peso, mas que por ayudar, sino por la pena que me da o por la culpa que me genera ver a esas personas y yo no hacer nada, entonces yo creo que eso es bastante perverso." Las representaciones, las imágenes generadas desde la publicidad, se instalan socialmente, forman parte de la construcción del mundo, discapacidad no sólo asociada a caridad, sino a consumo, a discapacidad visible, a discapacidad recuperable. Con esta dificultad se encuentra el Estado en un inicio, por una parte y por otra éste también reproduce las representaciones generadas; la dificultad se concentra a fines de los noventa cuando se intenta establecer un cambio en las percepciones, en las distinciones y en el refuerzo de éstas a través de la propia política social. Significa un rompimiento de los elementos simbólicos instalados, la destrucción de las propias percepciones, de las verdades que han sido asentadas.

Puedo interpretar que la instalación del tema de la discapacidad desde la Teletón (institucionalización privada en torno a la discapacidad), descompromete a la sociedad, la vincula al tema desde la publicidad acotada a un momento y la desvincula de la vida cotidiana, se mantiene la relación en donde se espera que otro se haga cargo, se mantenga la invisibilidad y no se apunta a cambios en lo simbólico o relacional.

\section{Durante la década de los noventa}

Los noventa se caracterizan por constituirse en un período en que se reconocen o emergen determinados temas sociales. "... hasta antes del noventa el tema no estaba incorporado en la agenda social, eso está claro, no eran un grupo prioritario definido por el Estado." Un elemento importante es el contexto de cambios sociales, la recuperación de la democracia no sólo en el país sino también en la región, así como los procesos de consolidación del modelo económico, podría afirmar, aseguran la necesidad de situar a determinados sujetos y sus necesidades dentro de los focos de atención de las políticas sociales, lo que establecería elementos de estabilidad en el sistema social y económico.

A través del discurso de los entrevistados se señala que el cambio en la década se produce tanto por condiciones, aperturas internas como externas, es decir por condiciones internacionales que incorporan la temática desde lo técnico, político y económico. Las condiciones nacionales se relacionan con la democratización, la que permite el reconocimiento de otros.

La apertura a determinados temas estaría vinculado a un nuevo contexto socioeconómico y a un nuevo rol del Estado, la emergencia de temáticas relativas a los derechos de las personas y su relación con la economía, favorecen la incorporación de sujetos invisibilizados discriminados,“... el tema de la discapacidad empezaba a tener un peso asociado a un tema emergente, quizás en un plano similar a algunos temas de salud, a algunos temas de minorías étnicas, o sea el tema global de igualdad de oportunidades, de discriminación; entonces, en ese sentido como que pasaba a la idea de que desde el 
gobierno había una voluntad también de privilegiarlos respecto a la presencia que había tenido antes". Cabe indicar sin embargo, que se destaca no sólo un contexto que facilita la instalación prioritaria de la temática sino también la existencia de una voluntad política que recoge la posibilidad, de no sólo instalar el tema en la agenda, sino también privilegiarlo y generar estrategias que posibilitan abordarlo desde la política social.

En asociación a la emergencia de los temas, se vincula la idea de dejar de ocultar el tema, del sacar a la luz, de hacerlo público de desinstitucionalizarlo, ponerlo en lo social. Esta desinstitucionalización no sólo significa que el Estado se encargue del tema como un tema prioritario, sino también el posibilitar aperturas en el resto de la estructura estatal de modo de abrir el tema, en un inicio normalizarlo, y posteriormente, ampliarlo socialmente, generar espacios que permitan la inclusión de los sujetos con discapacidad.

Para los entrevistados no basta con que la estructura distinga a determinados sujetos. La relevancia o prioridad, el espacio que se le entregue al tema se determinará desde la ubicación que el tema ocupe en el discurso, por un lado, en las estrategias, y presupuesto que se designe así como el tipo de estructura que conlleva. "y también si se hace una historia de seguimiento de ese tema, que también empezó como programa y ahora ya está en vías de convertirse en un... o sea hoy día está en vías de convertirse en un Servicio digamos del adulto mayor, hay una preocupación que sí yo creo que se nota, desde el aparato del Estado". Otro elemento a destacar es la relevancia del tema que se mide en la propia estructura, desde el lugar que ocupa la problemática dentro del Estado.

En este proceso se distingue que la institucionalidad se vio retroalimentada con la participación y redefinición del rol y representaciones de las agrupaciones e instituciones asociadas a determinados sujetos con discapacidad. Éstas, por ejemplo, permitieron abrir distinciones a "nuevos" sujetos con discapacidad, se hace evidente por ejemplo la discapacidad psiquiátrica, auditiva, etc. en la medida que también las agrupaciones salen del mundo de lo invisible, de lo privado y se relaciona con el Estado a través de los proyectos o estrategias elaboradas para la generación de un trabajo conjunto que permitiera acoger y conocer, re - conocer la diversidad en el mundo de la discapacidad.

\section{A fines de los noventa.}

Como he señalado la instalación de la temática en la estructura del Estado reconocida por los y las hacedoras de políticas sociales, ha significado un cambio, al final de la década, ha un cambio en el propio sistema estatal con el fin de modificar la producción de indiferencia respecto del tema y de los sujetos con discapacidad, lo que significa un esfuerzo por establecer un cambio cultural, tanto al interior de la estructura como fuera de ésta, en una redefinición del sujeto con discapacidad, sobre la base del reconocimiento de éste en sus derechos y desde allí la elaboración de estrategias que en permitan efectivamente la inclusión de éstos. Es decir un cambio que apunte a la inclusión no sólo en la exclusión, sino efectivamente una inclusión al sistema, así como un cambio en los mecanismos asociados a la producción de indiferencia por parte del Estado.

Un elemento importante en la resignificación de los sujetos es el cambio que va desde la representación de los sujetos centrada en la discapacidad al reconocimiento de un sujeto que presenta condiciones de discapacidad, la diferencia fundamental no ésta en ellos sino en las posibilidades o limitaciones que el sistema permite en la medida que reconoce las diferencias entre los sujetos. En un inicio la estructura define la acción, el abordaje (el acercarse a la problemática) desde una distinción que sitúa a la discapacidad dentro de la condición de 
pobreza, asociada a otros aspectos como salud, educación “...yo podría abordar el tema de la discapacidad dentro de la pobreza, abordarlo desde del trabajo, desde la educación, desde la salud... y la variable discapacidad sería una más, que es lo que se propone hoy día..." esta afirmación grafica el proceso de incorporación de la situación de discapacidad desde la transversalidad del abordaje, si bien se focaliza en los sujetos, se debe elaborar una estrategia de conjunto de modo de optimizar y verdaderamente incluir a los sujetos con discapacidad en procesos de autodeterminación y no de dependencia.

El que la problemática sea abordada, asumida desde dentro del sistema, tiene su correlato social en donde se incorpora la temática en la sociedad. Se reconoce desde los entrevistados la resistencia social respecto a ésta, desde allí la necesidad de enfrentarla, desde un cambio cultural, en las representaciones de los sujetos con discapacidad, de modo de traducir efectivamente un reconocimiento de los derechos de éstos, "... lo otro es para la sociedad por así decirlo, el desafío...en primer lugar desde el punto de vista ético...nos encontramos con una serie de principios donde el principal podría ser el tema del respeto, respeto por esas personas....en términos de sus derechos."

En esta última etapa de la década, otro elemento a destacar es que la situación de las personas con discapacidad se visualiza desde dimensiones que se entrecruzan, la solución de las condiciones de vulnerabilidad de las personas con discapacidad es posible en la aproximación, coordinada de esfuerzos, que optimizarán los recursos disponibles, éstos en si mismos aislados y sin un cambio cultural, que apunte a un cambio en las relaciones de discriminación y exclusión no resuelven la situación de los sujetos con discapacidad, "...aunque tuviéramos millones y millones de pesos, si no hay trabajo coordinado con salud, con trabajo, con vivienda, no hay avance; estaríamos haciendo una acción muy desconectada y que a lo mejor sería un efecto inmediato, pero a largo plazo no genera las condiciones de desarrollo para las personas."

Cuando se produce un reconocimiento de los sujetos como sujetos de derecho (calidad de personas), se produce un reconocimiento de las necesidades se identifica y reconocen necesidades "similares" compartidas con sujetos sin discapacidad, "cuando estamos hablando de la situación de empleo que vive el país en general, afecta también a las personas en condición de discapacidad 0 a los microempresarios que son discapacitados. Lo mismo la educación". La dimensión del problema de la discapacidad es múltiple, por tanto la intervención no sólo es responsabilidad de un sector o estructura estatal, sino del conjunto de esfuerzos generados al interior del Estado.

La aproximación a la temática de la discapacidad desde el Estado continúa enriqueciéndose desde la experiencia desarrollada en otros países, “...creo que varias cosas tienen también un poco de la experiencia que ha ocurrido en países más avanzados que nosotros, también va apareciendo por ahí y la mayor parte de las cosas...".. Como ya he indicado éstas definiciones no sólo están sustentadas en lo técnico sino también en lo político y social, desde la evolución de las condiciones de la población, morbi-mortalidad y esperanza de vida de ésta, nuestro país requiere poner atención a ello en la medida que su población envejece y los indicadores tienen un comportamiento que permiten prever que el tema de la discapacidad es relevante.

Las propuestas que emergen en los últimos años de la década recogen la experiencia de los primeros años de trabajo en el tema, a lo que se suma el relevamiento y desarrollo de estrategias intersectoriales y estrategias de carácter integral que no sólo incluyen a los sujetos con discapacidad sino a todos los sujetos sociales. Los esfuerzos implican distinciones 
compartidas, tanto desde la definición de prioridades “... nosotros podemos proponer ciertas líneas de políticas, pero el Ministerio de Educación tiene otras ¿ya?. Y ahí es toda una cuestión de llegar a acuerdos, de llegar a consensos, pero eso depende de que el Ministerio de Educación quiera venir a hacerlo con nosotros, se basa más en los consensos y en los acuerdos que en las imposiciones ... de ciertas materias o líneas de políticas." Es decir, un elemento importante es resituar el tema como problema social que afecta a toda la población en cuanto potencial población con discapacidad.

La complejidad en la emergencia del tema de la discapacidad, forma parte de un sinnúmero de temas, un repertorio de temas que brotan, que salen a la superficie social, que emergen con el restablecimiento de la democracia, el sistema social, y el Estado se abre a nuevas distinciones e inicia un proceso de instalación, elaboración de nuevas distinciones como elemento característico. "Yo siento que en este gran repertorio de temas emergentes...hay algunos que tienen un ciclo de vida de mayor ficción que otros, supongamos el tema indígena...es un tema que desde el Estado no tiene una solución visible, como en el corto plazo, ni en el mediano, ni en el largo; no tiene un discurso muy positivo, posible, muy digno para el Estado, eso ocurre con algunos sectores también, en el tema cultural..."

Las observaciones de los otros, de los sujetos con discapacidad se va diferenciando en la medida que se incorporan otros elementos en ellas "...hoy día (la persona con discapacidad) está puesta digamos frente a la sociedad para luchar por una oportunidad de igual a igual y eso es producto... pienso que cada vez es más sorprendente que haya más igualdad entre los que tienen algún tipo de discapacidad y las personas que no tienen discapacidad." La observación es la de otro, un sujeto que se iguala, se iguala en su condición de sujeto, se visibiliza, se constituye en sujeto de derecho.

Al iniciar la entrevista con la pregunta: ¿ que prioridad cree usted que tiene el tema de la discapacidad?. Se abre un mundo de distinciones que van estrechamente ligadas a la experiencia no sólo laboral sino también personal de cada uno de los y las consultadas. La percepción de la relevancia o prioridad del tema está directamente asociada a quien habla y su ubicación en el sistema estatal.

Los y las entrevistadas coinciden en señalar que la temática y su ubicación prioritaria o no está determinada por contextos que van definiendo las conversaciones y la importancia o ubicación del tema en las conversaciones, distinciones que el Estado y el país realizan al respecto.

A fines de los noventa debido a la emergencia de otras temáticas y a la contingencia económica y social, existirían otros temas prioritarios para el Estado, de éste mismo modo, la prioridad, no sólo cambia al interior de la relación del Estado, sino también de ésta con la sociedad, “...no podríamos decir que es el tema en el cual el país esté preocupado..." Las prioridades son observables en las comunicaciones, los equipos dan cuenta de que el tema ha sufrido un cambio, el cambio es observable en las comunicaciones que se establecen tanto al interior del sistema estatal como también fuera de éste. En este sentido un elemento importante es el peso relativo percibido al interior de la estructura y en las decisiones políticas.

Para los entrevistados los temas que aparecen como socialmente relevante, están asociados a la contingencia del momento histórico y a su cobertura, por ejemplo, en los medios de comunicación. El posicionamiento en las comunicaciones ha ido cambiando pero aún se establecen tipificaciones relacionadas con elementos más de sensacionalismo, impacto en la noticia, etc. Lo que se busca a través de los medios de comunicación es encontrar un evento o suceso de carácter sensacionalista, que llame la atención, que mueva a las personas desde el 
golpe en lo afectivo, porque en si mismo no contiene valor para los medios, en la medida que no es un tema que se ve, "...uno percibe que los medios privilegian ese tema respecto de otro tema, que a lo mejor teniendo la misma importancia o un impacto social mayor, no viste tanto, no es mayor ficción. Pero en general nos cuesta un mundo poner el tema en los medios, en estos términos de sociedad o derecho..."

A partir de lo anterior, es posible analizar desde el discursos de los entrevistados que las tipificaciones, las representaciones de los sujetos a los cuales atiende el Estado repercuten en las distinciones que se realizan desde lo social, el entorno incorpora o re significa distinciones de los sujetos con discapacidad, "yo creo que en términos de la comunidad hay a lo mejor una ampliación del tema de la discapacidad desde el punto de vista de una demanda, yo creo que la demanda es mayor en términos de sociedad civil digamos, es mayor y un poco más, es a lo mejor una demanda que trata de ampliar el tema justamente a esa perspectiva, a la de igualarlo a un tema de igualdad de oportunidades, a un tema más de derechos políticos que de asistencia de planificación médica, más asociado al tema médico o al tema caritativo, que es el perfil que tenía antes..." Interpretar que este elemento de correlato en lo social, el cambio en las distinciones sociales provoca un cambio en las distinciones de los sujetos. Desde la sociedad, organización, desde el mundo ce la discapacidad realizan nuevas construcciones, comunicaciones y relaciones. Estas distinciones se posesionan socialmente, la visibilidad de los sujetos, se observa en la acción que estos mismos tienen en torno a la demanda de sus propias necesidades, éstas permiten articular un acercamiento distinto a los sujetos, lo que favorece a su vez la incorporación de nuevos aspectos a las tipificaciones. Es decir se produce una retroalimentación, redefinición de las observaciones de los sujetos y a su vez éstos establecen nuevas comunicaciones que los resitúa socialmente.

Los equipos distinguen diferencias a la hora de definir la prioridad del tema. La prioridad será definida de acuerdo a la percepción de involucramiento en el tema. Si las autoridades se comprometen esto se reflejará en el resultado del trabajo y de las iniciativas que se desarrollen. Por otro lado a las personas, a las cuales les afecta el tema este será relevante "...yo creo que habría que hablar desde el punto de vista de la población con discapacidad por un lado y de los que están cercanos o relacionados con ellos en algún momento, para los que el tema es altamente prioritario, y para el otro gran porcentaje de la población que de repente ve que hay otros problemas más importantes que el de la discapacidad". Quisiera señalar que las/ los hacedores de políticas sociales observan que la posibilidad de distinguir el tema como prioritario tendrá relación con la visibilidad de la temática y con la cercanía que se tenga a ésta, es decir la posibilidad de que sea visible permite la elaboración de distinciones. En la medida que el tema es invisible, "lejano" los sujetos no "ven" a los sujetos con discapacidad, los distinguen desagregados, fragmentados de su mundo, los ven fuera del sistema, desde allí se profundizan las dificultades para incorporarles en el sistema. Un ejemplo de ello lo constituye el desempleo que afecta a la población en general, problema que no es considerado como prioritario a la hora de relacionar el desempleo y discapacidad tema de empleo en estos momentos, el tema del empleo de personas con discapacidad no es tan prioritario, en este momento para los empresarios por ejemplo" Los equipos refieren que las distinciones que realizan los empresarios impiden vincular los problemas de empleo a la discapacidad, generando dificultades para la elaboración de estrategias que permitan la inclusión laboral de las personas con discapacidad.

Otro elemento es la observación de que la temática de la discapacidad se ha ido instalando en diversos espacios sociales identificando la complejidad de ésta, “... en general... si uno lo ve desde el Estado desde un lado, desde los empresarios por otro lado, y desde el resto de 
la sociedad yo creo que está presente en los tres actores de este triángulo importante... y... y tal vez a un nivel más o menos parecido...". Desde la institucionalidad se propone establecer alianzas que en un primer momento permitan aperturas, sociales como dentro del sistema, desde las sensibilidades establecer campos de acción colectivos, acciones que favorezcan la inter - institucionalidad y un abordaje integral de la temática, como reflejo del elemento de reconocimiento de la complejidad.

Los entrevistados al dar cuenta de la instalación y prioridad del tema de la discapacidad, dan cuenta de los sujetos, de la estructura, la relación que existe entre ambos. La relevancia va cambiando de acuerdo a la contingencia y a las propias percepciones de quienes dirigen la política. Se observa que desde sus inicios a la fecha, el tema de la discapacidad ha cambiado, a fines de los noventa no ocupa el sitio prioritario como en sus inicios “... yo no lo vería tampoco olvidado.... o sea está presente, todo el mundo aquí sabe que existe el tema, que se trabaja el tema, se incorporó en la encuesta CASEN de este año, del año 2000..., entonces está absolutamente vigente".

Otro elemento que distingue este proceso de resignificación de los sujetos es el proceso de transformación del tema, las y los hacedores de políticas sociales que este habría perdido prioridad y relevancia en la medida que el tema, es traspasado al sector privado por medio de la implementación de acciones específicas. "Yo creo que no ocupa en este momento un lugar preponderante, principalmente porque está... el FONADIS y porque se lo entregaron al sector privado también, hemos trabajado con ellos y justamente para ir traspasándole algunas... no responsabilidades, pero sí acciones, que desarrollan ellos y que hay en conjunto ... en base a lo que es el marco general de discapacidad, eso es claro".

(iii) Elementos de inclusión/ exclusión que utilizan las estructuras estatales y las políticas sociales en los procesos y representaciones de sujetos emergentes. (por qué).

Tabla resumen:

\begin{tabular}{|l|l|l|}
\hline \multicolumn{1}{|c|}{ RESPECTO DE } & \multicolumn{1}{|c|}{ EXCLUSIÓN } & \multicolumn{1}{c|}{ INCLUSIÓN } \\
\hline Condiciones políticas & $\begin{array}{l}\text { Años 80: Condiciones } \\
\text { políticas desfavorables: } \\
\text { dictadura } \\
\text { no está en la agenda/ no } \\
\text { existe política social/ no es } \\
\text { prioridad }\end{array}$ & $\begin{array}{l}\text { Años 90: condiciones } \\
\text { políticas favorables: } \\
\text { democracia } \\
\text { Se pone en la agenda } \\
\text { social/política/prioridad }\end{array}$ \\
\hline $\begin{array}{l}\text { Respecto del tema de la } \\
\text { discapacidad }\end{array}$ & $\begin{array}{l}\text { No se conoce } \\
\text { No se registra/no hay datos } \\
\text { estadísticos. } \\
\text { No se sabe } \\
\text { Oculto/sobreprotegido }\end{array}$ & $\begin{array}{l}\text { Se conoce. Investigaciones } \\
\text { Se cuenta con } \\
\text { registro/Casen } \\
\text { Se sabe } \\
\text { Visible/autónomo }\end{array}$ \\
\hline Asociado a & $\begin{array}{l}\text { Minusvalía: centrado en la } \\
\text { carencia, limitación, } \\
\text { enfermedad }\end{array}$ & $\begin{array}{l}\text { Centrado en el sujeto, con } \\
\text { capacidad diferente. } \\
\text { Integra al entorno }\end{array}$ \\
\hline $\begin{array}{l}\text { Respecto del sujeto con } \\
\text { discapacidad }\end{array}$ & $\begin{array}{l}\text { No sujeto } \\
\text { No ser = no hacer }\end{array}$ & $\begin{array}{l}\text { Sujeto } \\
\text { Ser = hacer }\end{array}$ \\
\hline
\end{tabular}


A continuación presento el análisis a través del cual me referiré a los elementos que desde el discurso están contenidos en las estructuras sociales que dan cuenta de la exclusión/inclusión de las personas con discapacidad.

El cuadro anterior muestra distinciones respecto de los mecanismos de inclusión/ exclusión de acuerdo a los procesos sociales y políticos que permiten o cierran la elaboración de distinciones, que se traducen en invisibilidad o visibilidad del tema, desde la estructura estatal así como también al interior de la sociedad. Estas distinciones asociadas a las capacidades, como señalé en un primer momento, centran las dificultades en los sujetos y desde allí las dificultades para la inclusión de éstos o no al sistema social.

Finalmente el reconocimiento del sujeto abre nuevas distinciones que favorecen pensar en un primer momento en la apertura del sistema, la generación de procesos de inclusión a su vez establecer nuevas distinciones, éstas se complejizan y aparece el mundo de la discapacidad y sus propios procesos.

\section{Condiciones políticas}

Como he señalado anteriormente los/ las hacedoras de políticas sociales identifican un antes después en el tema de la discapacidad. El contexto político social no permite aperturas hacia la distinción de los sujetos sociales durante la dictadura, los sujetos no son reconocidos como tales, las políticas sociales se operacionalizan en la lógica de grandes distinciones y no reconocen las diferencias de los sujetos a los cuales se dirige. En este sentido cabe destacar que la propia demanda de los sujetos que se oponen a la dictadura que luchan por el restablecimiento de las relaciones democráticas, así como del ejercicio de los derechos y las mejoras en las condiciones de vida, elaboran desde una demanda conjunta en que contiene particularidades el restablecimiento de condiciones democráticas. Lo anterior cambia en la medida que la Concertación realiza acuerdos previos y recoge necesidades específicas en la idea de fortalecer el proceso y encauzar éste, establece acuerdos previos en los que se compromete, en el entendido de ser éste el nuevo gobierno, a la generación de espacios y políticas que permitan la diferenciación de la población, así mismo la elaboración focalizada de políticas, desde donde intenta establecer nuevas distinciones con el fin de dar respuesta y optimizar recursos de acuerdo a las características y demandas propias.

La definición de un nuevo modo de abordar la problemática social, la focalización rompe los modos en que se desarrollaban las intervenciones desde el Estado, se requiere, en este nuevo contexto de un marco legal, regulación de las acciones y fondos destinados a grupos definidos como "vulnerables".

Como ya he señalado anteriormente los noventa se caracterizan como años en que se reconocen o emergen determinados temas sociales. “... hasta antes del noventa el tema no estaba incorporado en la agenda social, eso está claro, no eran un grupo prioritario definido por el Estado." El contexto de cambios sociales, la recuperación de la democracia no sólo en el país sino también en la región, así como los procesos de consolidación del modelo económico, podría afirmar asegura la necesidad de situar a determinados sujetos y sus necesidades dentro de los focos de atención de las políticas sociales, lo que establecería elementos de estabilidad en el sistema social y económico.

La apertura del Estado a la temática de la discapacidad, así como el reconocimiento de los sujetos con discapacidad, no sólo permea a éste sino también a la sociedad, se abren nuevos sistemas, no sólo por las necesidades de la nueva contingencia política y social interna sino 
también por procesos y requerimientos internacionales, un ejemplo de ello es la empresa, condiciones en la construcción, etc. Se establecen cambios en las estructuras, en las comunicaciones y relaciones no sólo desde la institucionalidad emergente y los sujetos, sino también de éstos con otras instancias como son los sectores empresariales.

Hasta antes del surgimiento de la estructura de FONADIS, la discapacidad era atendido como problema médico, social, etc. lo que se reforzaba en la representación de un sujeto enfermo, sin capacidades, limitado en éstas.

El cambio, permite un reconocimiento de un sujeto de derecho, que requiere la implementación de mecanismos que apunten a una mirada y abordaje integral de la temática, desde donde es posible la instalación de la estructura posibilita la canalización de iniciativas, recursos, y propuestas que van más allá de resolver o aportar en la mejoría de las condiciones de salud de las personas. Es decir, permite la comprensión del tema desde una mirada más amplia. La clave, en un primer momento, es el reconocimiento de éstos, personas con discapacidad, como sujetos de derecho. "...hasta el año noventa, ochenta y nueve, pongámosle noventa, todo el tema de la discapacidad es visto como un problema de salud, entonces el Ministerio de Salud era el que se preocupaba de eso, sin de repente ser necesario que él entrara a actuar porque el problema de las personas no es un problema de salud, sino eran otros los problemas de los discapacitados. Por otro lado, estaba qué sé yo el Ministerio de Educación, con lo que era la educación especial, pero no estaba una presencia del tema en lo que es la agenda política o la agenda social del momento." El cambio en la década de los noventa apunta a la visibilización de los sujetos lo que tiene una traducción en las agendas políticas/ sociales.

La voluntad política no sólo significa un cambio para la instalación del tema sino también la posibilidad de mantener la prioridad de éste, "....cambia también hasta cierto punto lo que era la forma de hacer política social hasta ese momento, y se centra más en grupos que en personas, entonces se definen cierto grupos de trabajo, grupos prioritarios y entre esos metieron al tema de la discapacidad, a las personas con discapacidad..."

Si observamos las observaciones éstas señalen que la institucionalidad permite la incorporación de la temática, en una estructura nueva en la década, para incluir a nuevos sujetos, elabora políticas sociales, incorpora y coordina la intervención y abordaje intersectorial de las temáticas. "MIDEPLAN siempre estuvo cercano, muy cercano a esto... y básicamente yo creo que, o sea, más allá de los compromisos también por una idea de avanzar en la política pública, o sea la política pública tiene que ir incorporando los temas emergentes para que pasen a tener una planificación un poco más regular, sistemática y... digamos y estable en el tiempo." Sin embargo, se distingue que el tema de la discapacidad es un tema que requiere ser instalado socialmente, para ello se generan estrategias "el Estado hoy día (en los inicios del FONADIS) se compromete, ...a realizar acciones... por lo tanto tenemos que asignar recursos, traspasar recursos a como de lugar, ...para instalar el tema, para levantar una realidad".

Las condiciones para as egurar procesos de integración dicen relación con el contexto que se abre a la discusión al reconocimiento del otro a través del dialogo, del reconocimiento o del conocimiento de las necesidades, o de las condiciones y características de cada uno. "... es posible establecer justamente la relación entre democracia por así decirlo e integración... el tema del respeto y los derechos de las personas, entonces eso ya empieza a funcionar de un modo un poquito distinto..., pero el paso, por así decirlo entre la dictadura y la democracia ... creó condiciones de ese tipo, condiciones políticas que después se 
pueden haber traducido en recursos, en condiciones sociales... en dictadura, justamente por el tema de otros contra valores, que se oponen al tema de la integración social de este tipo de colectivos, habían sido más desechables por así decirlos, más ninguneados, o más invisibles."

No basta con que la estructura distinga a determinados sujetos, sino la prioridad, que se le asigne al tema se determinará, desde los equipos entrevistados, desde la ubicación que el tema ocupe en el discurso, por un lado, en las estrategias, y presupuesto así como el tipo de estructura que implica. "y también si se hace una historia de seguimiento de ese tema, que también empezó como programa y ahora ya está en vías de convertirse en un... Servicio digamos del adulto mayor, hay una preocupación que sí yo creo que se nota, desde el aparato del Estado, ha tenido esa evolución y además en un lapso diría yo relativamente breve... la que lideró eso un poco fue otra primera dama con el tema del adulto mayor, esa fue como su banderita, y hoy día eso está a punto de convertirse en un Servicio si es que ya no está creado el Servicio. Entonces eso, como te digo te puede establecer una comparación en relación a cómo se prioriza, o a quién se prioriza". El problema gana visibilidad, se le considera problema social y la evolución en las formas de enfrentarlo estructuralmente como programa en un inicio, luego a constituirse en un fondo nacional y actualmente lo que esperan los/ las hacedoras que éste se constituya como servicio, lo que le otorga mayor incidencia y posibilidades en el abordaje de la problemática.

Un elemento que destacan los entrevistados es que el cambio de la estructura, por tanto el posicionamiento de la problemática en ésta, se ve asociada a la comprensión de la problemática en su actual magnitud, como un problema que afecta a las sociedades que se encuentran en proceso de envejecimiento de la población.

En síntesis la apertura a determinados temas estaría vinculado a un nuevo contexto socioeconómico y a un nuevo rol del Estado, la emergencia de temáticas relativas a los derechos de las personas y su relación con la economía, favorecen la incorporación de determinados sujetos, sujetos invisibilizados, discriminados "... el tema de la discapacidad empezaba a tener un peso asociado a un tema emergente...a algunos temas de minorías étnicas, o sea el tema global de igualdad de oportunidades, de discriminación...desde el gobierno había una voluntad también de privilegiarlos respecto a la presencia que había tenido antes".

\section{Respecto del tema de la discapacidad}

Como he señalado anteriormente los sujetos no son distinguidos, se les excluye, de las prioridades y focalización de la política pública. Esta exclusión se reproduce en el mundo de la discapacidad en cuanto se establece internamente una matriz para proteger de la discriminación, estrategia que se orienta a la sobreprotección, al ocultamiento de los sujetos.

Desde el discurso de las personas entrevistadas se afirma la idea de que las familias y el entorno favorecen o no procesos de inclusión / exclusión de las personas con discapacidad “... ese niño (al que representa la Teletón) bueno, también lo hemos observado en sus características, en esa cultura va creando más reticencia, una autoimagen más pasiva" .

Me permito afirmar a partir del análisis desarrollado que la sobreprotección como modo cultural del mundo de la discapacidad fortalece las relaciones de dependencia y dificulta los procesos de integración de las personas "a diferencia de un cabro que tiene el mismo problema, pero está en un gimnasio de rehabilitación en Renca, donde es mucho más 
pinganilla todavía, a pesar de su condición de discapacidad... obviamente afectan sus procesos de integración: para uno se les hace más difícil, para el otro es más fácil porque incluso es más canchero, pero yo creo que son realidades tanto o más complejas .... Si un cabro es sobreprotegido sin discapacidad obviamente genera comportamientos que en el mundo actual le trae mucho más problemas que a un cabro que es mucho más independiente", la sobreprotección relega y hace dependiente a la persona con discapacidad, la excluye doblemente, en cuanto también impediría la posibilidad de que esta se tomara los espacios, se apropiara de los espacios a los cuales no pertenece. Ahora bien es importante destacar que esta sobreprotección nace en respuesta de cuidado a la exclusión que son objeto no sólo los sujetos con discapacidad sino también las familias de éstos.

La distinción de las personas con discapacidad, se produce en un primer término en relación a la discapacidad y a la familia. Se les visualiza desde la falta de fuerza, la debilidad, "De cómo vemos las organizaciones o agrupaciones: " (las organizaciones de personas con discapacidad) también son como más débiles...", en la debilidad para resistir, escasa fuerza. Ahora bien a fines de la década de los noventa se produce un cambio en la distinción, no sólo desde la representación de si mismos como sujetos y familias con discapacidad, sino también un cambio en la relación con y desde los/ las hacedoras de políticas sociales, la organización no sólo plantea demandas de asistencialidad sino más bien de autonomía, de romper con la sobreprotección que excluye, es más bien orientar la demanda a un cambio relacional, comunicacional que implique un reconocimiento de las capacidades y derechos sociales de los sujetos.

No se sabe de los sujetos. Algo similar ocurre respecto a las organizaciones, estás emergen en relación a las carencias de los sujetos, como un modo de enfrentar la ausencia de políticas sociales, de compartir el conocimiento o acercarse a éste, pero en la exclusión que esta representa. En contraste hoy, desde una nueva representación de los sujetos estas organizaciones se plantean abiertas, en una relación, elaborando comunicaciones diferentes con el entorno, visibilizado a los sujetos, mostrándose como sujetos, familias con discapacidad, en la exigencia de derechos y de una relación igualitaria.

\section{Discapacidad asociada a:}

Como he señalado anteriormente la discapacidad en la exclusión está asociada a la idea de minusvalía, de capacidades limitadas, se produce un antagonismo entre normalidad y anormalidad, es decir aquel que es anormal, es excluido. La paradoja emerge cuando a pesar del esfuerzo que el sujeto haga, la inversión que intente hacia la recuperación de la normalidad, este se mantiene en situación de exclusión, ejemplo de ello pueden ser las escuelas especiales que establecen como fin el generar una educación acorde a las limitaciones del sujeto pero que no permiten que éste se integre socialmente la educación no se constituye en un vehículo de movilidad social.

Las estrategias desde la Teletón por ejemplo apuntan a un cambio respecto a la minusvalía los sujetos, es una inversión en aquellos aspectos de los sujetos que presentan dificultades, pero que no apuntan a un cambio en la relación Estado sujeto, ni a la relación sociedad personas.

La inclusión aparece con las distinciones que se centran en la condición de personas y donde la discapacidad se constituye en una característica más del sujeto, que por cierto requiere determinadas atenciones, sociales, de salud, educación, laboral, etc. las distinciones apuntan a las limitaciones que establece el entorno cultural, simbólico o físicas y que impiden o dificultan la inclusión. Es decir apuntan a un cambio en las distinciones de los sujetos con discapacidad, 
en el entendido que estos son sujetos con derechos que deben ser respetados desde donde la política y las acciones deben ser orientados asegurando condiciones de igualdad de las personas.

\section{Respecto de las personas con discapacidad}

Volvamos atrás, sobre la idea de la invisibilidad de las personas con discapacidad. El sujeto con discapacidad es excluido en cuanto es cosificado, es distinguido desde la falta y no desde la condición de sujeto. A lo anterior se suma la respuesta de protección, que intenta salvar pero que termina excluyendo desde el mundo de la discapacidad a través de la generación de mecanismos de sobreprotección.

El sujeto no es, en cuanto no es distinguido, es representado desde donde no puede estar. No es en la medida que no accede a mecanismos de movilidad e identidad social como lo son la educación el trabajo. No accede, simbólica ni físicamente a éstos.

En los procesos orientados al reconocimiento de la calidad de sujetos, se produce un salto cualitativo al reconocimiento del otro desde sus capacidades, características, particularidades, desde sus necesidades. La representación de éstos se da en un vínculo con el entorno, en cuanto se requiere establecer nuevas comunicaciones para el reconocimiento de la calidad de sujetos, del ser y del hacer.

Desde este nuevo marco de distinciones se abren espacios que permiten pensar y construir estrategias orientadas a resguardar las oportunidades que favorecen no sólo a los sujetos con discapacidad, acceder a determinados espacios y derechos sino también el resto de la sociedad a abrirse a la diversidad y desde allí reconocer a los otros, a los sujetos en sus diferencias como posibilidad de enriquecer las identidades, las posibilidades de ser/ hacer.

Los hacedores de políticas sociales establecen distinciones diferenciando las necesidades de acuerdo a las características, por ejemplo etáreas de los sujetos con discapacidad "...dentro de las necesidades, hablar de los problemas de la gente dentro de las edades". Se identifica que niños y niñas tienen necesidades de integración, " la necesidad poder integrarse en su nivel, el tema de la educación, del proyecto de integración educativa". El discurso de los entrevistados se orienta a la idea de la integración, la idea de llevar a los otros (excluidos) a mi mundo, a compartir el mundo "hay que darle mucha importancia y que hoy día no se le está dando a... la integración yo diría tal vez infantil, primera infancia, segunda infancia, los más chiquititos..."

Las necesidades de los adultos están asociadas a la posibilidad de desarrollar una actividad laboral, 'En el adulto, el adulto joven hacia arriba, ver las posibilidades de integración laboral", desde esta necesidad se implementan acciones orientadas a mejorar y promover la integración de las personas con discapacidad "y hay muchos proyectos que están en línea de formación, capacitación e integración laboral para buscar la forma de buscar microempresas para buscar trabajo a discapacitados que es una las necesidades yo diría más importantes de este grupo etáreo, y en los adultos también el proceso integrativo...que los adultos permanezcan vigentes digamos en la sociedad y a través de grupos de adulto mayor o con actividades específicas que los mantenga..."

La inclusión en los espacios educativos y laborales, “....hay dos frentes básicos: la educación y el trabajo, dos etapas", se constituyen en la manifestación explicita de integración de las personas con discapacidad, "normalmente la inserción al trabajo yo siento que es como la 
culminación de un proceso de integración. Ahora bien la inclusión se dará en la medida que las estrategias estén dirigidas a incorporar a las personas con discapacidad en espacios ocupados preferentemente por personas sin discapacidad "una de las grandes aspiraciones de una persona con discapacidad, yo creo que es incorporarse a un trabajo...un lugar de trabajo donde comparta con personas sin discapacidad, donde pueda demostrar su potencial y convivir con sus limitaciones específicas". Cabe destacar que sin embargo se plantea la necesidad de la integración, al mismo tiempo subyace la afirmación de que las personas con discapacidad deben demostrar sus habilidades y posibilidades de convivir con la propia limitación.

Las aperturas a la integración vienen muchas veces asociadas a las experiencias personales, las que de alguna manera ponen a prueba los discursos y las ideas, desde la vida cotidiana respecto a la discapacidad "...yo por ejemplo en lo personal como dato no manejaba, no tenía claridad respecto a la importancia de la inserción laboral o de la integración en el colegio, por ahí me tocó conocerlo por el colegio de mi hijo, en el colegio en que ha estado hay integración...".

El trabajo y la educación abiertos a todos los sujetos de modo de que no excluir a partir de las distinciones que se han centrado en la negación, en la invisibilidad o codificación, "educación, integración educativa, es decir que realmente la escuela se transforme en un espacio para todos, que no excluya a los niños con discapacidad, sigue siendo importante el tema ahora de la integración, de la plena integración social, es decir, hoy día existen más elementos para exigir la plena integración: las normas, la aplicación de las normas, el cumplimiento de las normas..." la integración es la transformación de los espacios como espacios que incluyan las diversidades, en marcos que permitan regular ésta. En este sentido cabe destacar que la implementación de normas permitiría resguardar las acciones orientadas a la inclusión de los sujetos, desde sus derechos.

La inclusión era vista a través de la capacitación, luego por la generación de espacios laborales “... el trabajo sigue siendo (una necesidad), (...) pero ya no es el tema de la capacitación, derechamente a la colocación laboral, que la gente tenga trabajo, trabajo digno, competitivo y que se prepare, eso; o que genere su propia microempresa, eso." Sin embargo se señala que actualmente el traspaso de capacidades se orienta más bien a la autonomía, a la posibilidad de incorporarse al sistema laboral, o que genere sus propios mecanismos de integración por medio del trabajo.

La inclusión se presenta desde el entorno, es la empresa quien se abre “... incluso las empresas hoy día dicen: no, si los capacitamos nosotros, para qué los van a capacitar antes en oficios, en gasfitería, en mano de obra barata, y lo posicionamos en un tema realme nte digno, competitivo, productivo; pero por lo tanto hay que exigirle más, por lo tanto tiene que hacer también un clic la persona, el beneficiario de ese proyecto y decir: okey, me voy a tener que exigir más..." el posicionar a los sujetos, es entregarles, a partir del desarrollo de capacidades laborales un espacio de valoración social. A su vez esta incorporación en lo social exige un cambio relacional, se requiere no sólo un cambio en los espacios laborales.

Para los entrevistados la participación en b social, permitirá la inclusión de las personas con discapacidad 'Yo creo que más que asignar recursos para mejorar calidad de vida en términos de objetos, así, o de ayudas puntuales, la incorporación al medio social es un tope bien alto en las aspiraciones de las personas con discapacidad." El elaborar estrategias de desarrollo político destinadas a la integración se relaciona con la idea de sujeto. 
Estrategias aisladas no se constituirán en espacios de integración, sino estos deben construirse como estrategias coordinadas, los campos de acción deben coordinarse "En algún momento fue prioridad la educación, pero la educación no basta para integrarse socialmente; salud dijimos también, tampoco basta para integrarse socialmente".

Un elemento importante, relacionado a lo anterior es la idea de accesibilidad, la idea de acercarse a, de inclusión, como entrada o paso hacia lo social, hacia el reconocimiento "el tema de la accesibilidad, se llama, o sea, trabajo, educación y accesibilidad...". La rehabilitación como habilitación, el hacer capaz, subsanar desde la integración, desde el reconocimiento de aquello que antes no era visible. “... por todas estas necesidades, necesidades que van desde el trabajo, la rehabilitación, digamos en todos planos: física, funcional, integral, el trabajo y la educación como lo importante, pero... y además una serie de otros detalles por así decirlo, elementos como es la accesibilidad al medio físico, a las telecomunicaciones, etcétera..."

Las distinciones de los/ las hacedoras de políticas sociales, reconocen en el proceso de construcción de representaciones un proceso orientado a la identificación de las necesidades, las que pueden ser vinculadas a los procesos se inclusión/ exclusión, "yo creo que al principio se partió de que una de las necesidades prioritarias era por ejemplo (...) la formación, a partir de ahí se fueron observando a través de todos los concursos y todo lo que se iba desarrollando, que las necesidades son más allá que exclusivamente el acceso al trabajo ..." las acciones desarrolladas permiten en un primer momento, la visibilización, el reconocimiento de los sujetos, se produce un cambio en las representaciones tanto desde el Estado como desde lo el entorno social, e incluso dentro del mismo mundo de la discapacidad.

La integración de las personas con discapacidad, desde el habla de los/ las entrevistadas se produciría a través del acceso a "...la tecnología hoy día yo creo que es un elemento importante, la incorporación de tecnología de punta para las personas con discapacidad y todos aquellos que se relacionen con ellos." La tecnología, permite establecer nuevas comunicaciones "...uno ha ido sumando, por ejemplo en el tema de la comunicación o sea también las necesidades son amplias..."

La ampliación de espacios sociales, a través de la participación, "...falta como el tema de mayor protagonismo, no tienen como un espacio a lo mejor de participación", la participación permitirá la visibilidad social.

Para los entrevistados se requiere fortalecer la participación de las organizaciones, es decir la "expresión", la comunicación. Para ellos las agrupaciones, organizaciones permiten retroalimentar al Estado en la elaboración, gestión de políticas, a través de la implementación de proyectos de desarrollo, son ellas las que actualmente se reconocen como contraparte en la evaluación, elaboración de las estrategias que se implementan.

\section{CONCLUSIONES DEL ESTUDIO}

El presente estudio ha centrado la observación sobre las observaciones que contienen las representaciones de sujetos mujeres y personas con discapacidad elaboradas por quienes corresponde la responsabilidad de generar políticas sociales orientadas a las mujeres y personas con discapacidad. Sobre los elementos contenidos tanto en los discursos, materiales como publicaciones y habla de éstos, es que he podido dar cuenta de las características, 
mecanismos, procesos, representaciones, que están presentes o que operan en los procesos de inclusión /exclusión social de mujeres y personas con discapacidad.

Creo que este acercamiento permite arrojar reflexiones orientadoras de las distinciones y los modos en que estas operan principalmente en la década de los noventa, período que se relaciona estrechamente con la emergencia pública de determinados sujetos sociales. En otras palabras desde la identificación de nuevos sujetos se han originado procesos que han permitido instalar tanto legal, como estatalmente mecanismos que aseguran que estos sujetos ocupen un espacio desde sus problemáticas, en la estructura del Estado.

Así mismo es importante señalar que cuando me refiero a sujetos emergentes y a políticas sociales, también me estoy refiriendo a mecanismos de inclusión/ exclusión. Estos serán los que permitan dar cuenta o describir los procesos a través de los cuales los sujetos quedan fuera o dentro del sistema social. En este sentido, también es posible observar si las políticas en su definición u operativización estarán favoreciendo construcciones de inclusión/ exclusión de los sujetos a los cuales afirman querer incluir de acuerdo al orden social que se define para ello.

En términos generales quisiera detenerme conclusivamente en los aspectos que surgen del análisis de los datos tanto respecto a los sujetos mujeres y personas con discapacidad, el detalle de lo planteado se encuentra en los análisis desarrollado, por lo que a continuación me permitiré detallar los aspectos que aparecen para ambos casos sin que esto signifique una comparación de ellos sino más bien detenerme en los aspectos que surgen coincidentemente.

Respecto a las representaciones de sujetos mujeres y personas con discapacidad, es necesario destacar que las representaciones sufren un proceso de transformación antes y durante la década de los noventa.

Las representaciones de mujeres y de personas con discapacidad están marcadas por la invisibilidad, las carencias, a esto se asocia la pobreza como evidencia de las carencias. Son referidos también como sujetos que no ocupan espacio en lo social, lo político, económico.

Los sujetos invisibilizados, cosificados, "no son, no están no hacen". Posteriormente se produce la elaboración de construcciones que le otorgan a los sujetos una valoración como tal, a través de las representaciones que se elaboran se les atribuye el "ser/ estar/ hacer". Esta atribución que les devuelve el ser, está estrechamente asociada a la ciudadanía, al reconocimiento de derechos.

Tanto mujeres como personas con discapacidad han sido distinguidos como ciudadanos, en la medida que se les reconocen derechos. Ahora bien, es importante destacar que si bien en la documentación, discursos, sobretodo a fines de la década se incorpora y reconocen la diversidad de sujetos, esto no es reflejado coherentemente en las entrevistas, en las construcciones y lenguaje de los y las hacedoras de políticas sociales. Las diferencias de clase, étnicas, sexuales no son parte de las representaciones que surgen en las conversaciones. Sin embargo este "vacío" es menos evidente en los discursos los cuales parecen contener de mejor manera la diversidad a la que se alude, incluso parecen recoger las demandas y el discurso de los mismos sujetos.

La invisibilización, la negación de los sujetos es normalizada hasta antes de la década de los noventa. Al elaborar distinciones que incorporan las diferencias, esta situación deja de ser natural, se transforma en leyes, en nuevas comunicaciones al interior del sistema social. 
Como he señalado anteriormente si bien los sujetos mujeres y personas con discapacidad, son distinguidos sólo desde la carencia, el discurso de los noventa al reconocerlos los incorpora desde el ideario de la igualdad. Si bien la preocupación de la política en el discurso aparece orientada a la totalidad de los sujetos, estos son identificados de acuerdo a criterios de focalización, de auerdo a criterios de pobreza. Sin embargo, en la década se plantea la igualdad, en cuanto reconocimiento de la ciudadanía y el discurso se orienta hacia la tolerancia, más que al reconocimiento e incorporación de la totalidad de sujetos, a la diversidad.

En cuanto a la descripción de elementos que resignifican a los sujetos mujeres y personas con discapacidad en la estructura estatal, de manera de permitir la incorporación de éstos en la estructura y política social; es decir el como, los elementos principales y coincidentes a destacar son los siguientes;

En términos generales tanto para el Estado como para la Sociedad antes de los noventa los sujetos mujeres y personas con discapacidad, no son prioritarios, son invisibilizados, los sujetos no son, no están, o se les ve respecto de otro. Para la sociedad los sujetos mujeres a diferencia de las personas con discapacidad, se les representa respecto del mundo privado o son preocupación de las ONG/ academia/ movimientos sociales. Las personas con discapacidad son visibles respecto de la Teletón como institución de beneficencia y sólo asociado a la situación de los y las niñas con discapacidad, los adultos con discapacidad no son parte de este fenómeno que se asocia a la caridad y al consumo.

Tanto para los sujetos mujeres y personas con discapacidad los inicios de los noventa, marcan una trayectoria de visibilización, en donde el Estado "asume", se constituye en marco institucional, legal. Se posiciona a los sujetos en la agenda política y también pública. Ambas temáticas están instaladas en el extranjero, son parte de los acuerdos y convenios que suscribe el país para incorporarse en los procesos de globalización y en los procesos económicos. Internamente se produce una suerte de traducción de estas conversaciones que vienen de fuera y que se constituyen en una nueva forma de establecer relaciones en el escenario democrático y de globalización que impone determinados requerimientos y que a la vez produce aperturas en cuanto son valoradas socialmente. Desde este proceso la instalación de los sujetos en la sociedad, emerge como una "realidad", desde donde el entorno se abre. Desde los sujetos mujeres y personas con discapacidad se pierde el temor a lo público, se rompe la frontera privado- público. Se reconoce social y simbólicamente a mujeres y personas con discapacidad como sujetos sociales, como ciudadanos, se habla de diversidad, se plantea la igualdad de los sujetos.

A fines de los noventa el proceso ya iniciado, luego de instalado en el Estado, se plantea el permear las estructuras y transversalizar (institucional y socialmente) las temáticas, considerando en ello la situación de los sujetos. Se evalúa la importancia de generar cambios culturales asociados a las imágenes de mujeres y personas con discapacidad, como estrategias que permitan la inclusión de los sujetos. Para la sociedad las temáticas de las mujeres empieza a verse como una temática compartida, de todos, se evalúa como problema social, se reconocen otros sistemas importantes y relacionados como es el sistema laboral, el que se constituye en un mecanismo importante de generación de nuevas comunicaciones que otorgarían a las mujeres y personas con discapacidad autonomía. El acceso de las personas a lo social es el mecanismo que permitiría la igualación de los sujetos en su condición de sujetos sociales. 
Respecto a los elementos de inclusión/ exclusión que utilizan las estructuras sociales en los procesos y representaciones de los sujetos emergentes, es decir el por que, es posible identificar aspectos coincidentes tanto para mujeres como para las personas con discapacidad.

Se produce un proceso social y político tanto internacional como nacional que permite el desarrollo de nuevos discursos, que favorece determinadas aperturas. La construcción de la democracia se asocia a la igualdad de los sujetos, al reconocimiento de los sujetos como ciudadanos con necesidades y realidades diferenciadas. La relación de estos elementos permitirá en un primer momento el reconocimiento de las mujeres y personas con discapacidad en cuanto se estén condiciones para reconocer la diversidad del mundo social.

La exclusión de los sujetos antes de los noventa está marcada por la invisibilización. Los sujetos son "confinados" a la invisibilidad a la dependencia, a ser ocultados, desprotegidos y dependientes. Los procesos de inclusión tanto institucional y social se produce con la identificación de otro, de los sujetos mujeres y personas con discapacidad y la caracterización de éstos. Los estudios realizados para dar cuenta de las especificidades de las realidades de los sujetos emergentes, permiten un acercamiento a las características y particularidades de éstos. En la medida que se conoce, se identifica, es decir en cuanto se hace posible elaborar distinciones se posibilita la referencia a éstos.

Las desigualdades, las brechas existentes entre hombres, mujeres y personas con discapacidad, da cuenta de que no sólo los mecanismos sociales sino también culturales, los estereotipos, las representaciones operan para discriminar, limitar, centrarse en la carencia, en la normalización de la exclusión. Al romper desde lo social y cultural con las representaciones: que hacen menos válidos a personas con discapacidad; subordinadas a las mujeres, se producen procesos de modificación simbólica y social de los sujetos emergentes. Se produce una integración de los sujetos al mundo social, sin embargo operan mecanismos de diferenciación en donde los sujetos mujeres y personas con discapacidad son posibles de identificar nuevamente en la complejidad del binomio inclusión/ exclusión.

Finalmente y como un elemento radical en los procesos de distinción inclusión/ exclusión, es la no distinción, el no reconocimiento, el no ser, la exclusión desde la no distinción. La incorporación de las distinciones, las representaciones de los sujetos emergentes en el lenguaje, instituciones, comunicación, permite la inclusión de los sujetos; como sujetos desde el ser/ estar/ hacer, desde la eliminación de las barreras que marcan o establecen las limitaciones/ fronteras del sistema.

\section{ELEMENTOS CONCLUSIVOS DE ORDEN GENERAL}

A partir del análisis y del desarrollo del estudio parece pertinente detenerme en algunos elementos que se constituyen en una remirada del tema, se constituyen en una resignificación de los aspectos encontrados a partir de éste desde los elementos teóricos y analíticos, de manera de dejar situada una reflexión e invitación que permita nuevas interrogantes y respuestas a partir de lo desarrollado en el presente estudio.

1. En general es posible afirmar que la emergencia e identificación de los sujetos se asocia a la sensibilidad del entorno. Es decir, un entorno que es "cercano" o "sensible" a otros, a lo otro podrá establecer distinciones que den cuenta de nuevos sujetos. 
Respecto a las diferencias en las construcciones respecto a los sujetos en los cuales he centrado la mirada. A través del material recopilado ha sido posible identificar que la sensibilidad respecto al tema de la discapacidad estaría dado por la "cercanía", no así la temática de las mujeres, en cuanto el ser mujeres no asegura, en sí mismo la sensibilidad respecto del tema, en otras palabras, respecto al tema de género, el ser hombre o mujer, la cercanía, la vivencia, no se constituyen en garantes en sí.

2. La emergencia e instalación de los sujetos como sujetos sociales, esta asociado a la idea de derechos. Sin embargo esta nueva ubicación social, esta inclusión en el sistema, a través de la acumulación de mecanismos respecto a los sistemas funcionales, no los incorpora integralmente sino mantiene el ejercicio de parcelación de éstos. Las nuevas construcciones de sujetos se resitúan respecto al sistema económico, el modo en que el sistema económico, neoliberal establece relaciones y comunicaciones, que intentan mantener as relaciones sociales dentro de los marcos predeterminados.

3. Las temáticas, los sujetos emergentes son relevados institucionalmente, no sólo por cuanto sujetos, sino éstos como parte de la relaciones económicas del país. Los sujetos mujeres y personas con discapacidad, "son valoradas" en cuanto, parte importante y trascendente en los procesos de crecimiento económico y desarrollo de los países.

Las mujeres y las personas con discapacidad, discursivamente se sitúan como sujetos activos y relevantes en los procesos de desarrollo. La incorporación de estos pasa a ser, simbólicamente y económicamente relevante para las relaciones que el país establece con el resto de la economía mundial, por cuanto esto permite establecer/ mantener marcos de relaciones de poder/ comunicaciones y orden social.

El Estado se sitúa como articulador de identidades, en la medida que sus acciones no sólo presentan un impacto en lo social, sino también en los ámbitos subjetivos y simbólicos de las personas.

4. Un cambio importante en los procesos de inclusión de los sujetos emergentes es la instalación legal de las temáticas. Se produce la instalación y legitimación no sólo simbólica de los sujetos sino social, siendo la instalación económica de los sujetos la inclusión más tardía, pero determinante de los procesos de autonomía y autodeterminación.

La elaboración de leyes, estructuras, reafirma el reconocimiento de nuevos sujetos, incluso la determinación del peso político de éstos está dado, para los/ las hacedoras de políticas sociales, por los recursos que se les asigna a las estructuras e importancia que éstas tienen dentro de la misma. La construcción de leyes, la oficialización de los sujetos emergentes, reafirma la calidad de sujetos de derechos de mujeres y personas con discapacidad.

Sin embargo, es posible afirmar que las leyes no hacen sino reflejar los estereotipos/ representaciones y a su vez estos están estrechamente relacionados con las leyes. Un ejemplo claro lo constituye la ley de violencia intrafamiliar. Este punto es importante en cuanto las leyes si bien "abren" o permiten aperturas desde el sistema, éstas sólo son las que el sistema permite o puede sostener para asegurar su mantención autopoiesis. Esto se evidencia a la hora de contrastar las demandas de los sujetos y los "avances" respecto a determinados temas, tales como el divorcio, aborto, educación integrada, etc. En síntesis, las leyes permiten aperturas, pero éstas a su vez son posibles ya que se han establecido distinciones (construcciones) y viceversa. Las leyes serán una oportunidad, pero a la vez 
contienen una limitación, en otras palabras instala un tema pero lo instala sólo desde las posibilidades sociales del sistema existente, desde los que legislan, desde sus propias aperturas y construcciones.

5. Las significaciones forman parte de la vida cotidiana, están presentes en los espacios intersubjetivos. La intersubjetividad es posible a través del lenguaje. A partir de estas afirmaciones quisiera detenerme en el proceso de emergencia de los sujetos sociales.

Los sujetos como he afirmado son sujetos invisibilizados, no están, no son, no hacen. El cambio en el lenguaje, en las construcciones respecto de éstos forman parte de un proceso mayor y paulatino a través del cual se hacen posibles las interacciones. Es decir, el ver/ aprehender al otro estará dado por las posibilidades de interacción.

Este punto resulta particularmente relevante por cuanto la visibilización de los sujetos, no asegura el establecimiento de comunicaciones, ni relaciones, la apertura del sistema se constituye en la posibilidad de interacción.

La posibilidad de distinguir a los sujetos, mujeres y personas con discapacidad, no asegura en sí mismo la posibilidad de un cambio relacional, o en otras palabras, las distinciones no aseguran, el establecimiento de comunicaciones, de relaciones entre estos. Las leyes elaboradas en torno a la discapacidad y a las mujeres, permiten establecer distinciones, por sobretodo establecen un cambio comunicacional lo que hace que éstas a su vez se traduzcan en acciones que van complejizando las comunicaciones y relaciones, van ampliando las relaciones en el contexto de la vida cotidiana.

6. El uso de imágenes que posicionan determinadas discapacidades, como las físicas y las mentales, un ejemplo particular el uso abusivo de personas niños/ as con síndrome de down, reafirman visualmente (validado sistema de conocimiento) la existencia de personas con ese tipo de discapacidades, por tanto siguen invisibilizadas/ excluidas las discapacidades que no se traducen como un impacto para los otros. En otras palabras se reafirma la instalación social, percepción "tipos" de personas con discapacidad, y no dan cuenta de la totalidad y diversidad de personas con discapacidad.

Algo similar ocurre con las imágenes de mujeres que se han utilizado en la década, en un inicio estas recogían imágenes de mujeres que habían sido parte de los procesos sociales de transformación social y de mujeres con características de pobreza o mujeres que realizaban trabajo temporal. Las imágenes reflejaban las características de mujeres a las que se orientaban políticas y programas sociales por ejemplo: mujeres temporeras, mujeres jefas de hogar, adolescentes, mujeres que sufren violencia. Sin embargo sabemos que la política orientada a las mujeres resulta impactar de diferentes maneras a la totalidad de mujeres y por cierto las relaciones hombres mujeres, a la sociedad en su conjunto en un contexto cultural diferenciado, que dará cuenta de relaciones y procesos reproducción del poder/ comunicaciones.

Resulta interesante poder describir y seguir la transformación visual que ha tenido la temática de la violencia. Las imágenes no han podido dar cuenta de la amplitud de la problemática, restringiéndola en los primeros años a mujeres de estratos bajos o medios, hoy se han instalado imágenes que permitan amplificar las características de las mujeres, pero el mensaje sigue acotando la temática de la violencia a la agresión física, no pudiendo reflejar la complejidad y el impacto de la problemática en otros ámbitos. 
En síntesis se visibilizan, construyen determinados tipos de sujetos, por ejemplo se visibilizan cierto tipo de personas con discapacidad, o cierto tipo de mujeres, excluyendo con ello a otros sujetos que por presentar otro tipo de discapacidad o presentar determinadas características como mujer, siguen siendo mujeres y personas con discapacidad invisibilizadas, excluidas.

7. El lenguaje estructura tipificaciones, símbolos que connotan socialmente. Estos determinarán la normalidad de la vida cotidiana. Este lenguaje, estas imágenes estructuradoras, redundan, o recursivamente, dan cuenta de los sujetos y de los procesos de inclusión/ exclusión. Si las representaciones de discapacidad se centran en imágenes de niños y niñas con discapacidad, como si la discapacidad sólo afectara a este grupo etáreo, esto redundará en las dificultades para establecer aperturas de los otros sistemas, por ejemplo para la incorporación de sujetos con discapacidad al sistema empresarial.

8. Con relación a la construcción de imágenes y a los modos en que se distinguen determinadas temáticas y los sujetos relacionadas, es posible afirmar que en el caso de la temática de la discapacidad este no es abordado con un perspectiva de género y al igual que la temática de las mujeres no se incorporan en las representaciones las distinciones de clase, de discapacidad y las étnicas, lo que redunda en la invisibilización de determinados sujetos.

Es decir, si bien a través de las políticas sociales ha ocurrido una modificación de las situaciones de exclusión en la exclusión de los sujetos emergentes en los que he centrado el estudio, es posible afirmar que se producen procesos de exclusión/ exclusión (en aquellos sujetos que no son distinguidos, desde las características de género, clase, discapacidad, etnia) y la inclusión/ exclusión.

9. Socialmente se han generado sistemas y estructuras que están determinados por la normalidad de la vida, construcciones que asentadas en el sentido común, en estereotipos y lenguaje se han constituido como parte de las estructura de exclusión de los sujetos. La invisibilidad se trasforma en estructura y en instituciones, esta a su vez la reproduce, tal es el caso de las escuelas especiales, en donde se construye y reproduce invisibilidad.

10. Las construcciones de sujeto, el conjunto de tipificaciones que afectan las relaciones y que a su vez establecen un orden social; es decir, la alteridad, los sujetos mujeres y sujetos con discapacidad construida en los noventa, están contenidos y contienen a su vez las epistemes, el lenguaje de las políticas de la década.

Resultaría importante dar cuenta del origen y de los modos de establecer estos marcos o epistemes, en este sentido he señalado que la presión que se ha ejercido desde los organismos internacionales no ha sido menor en los procesos de descripción del entorno.

Respecto a lo anterior, las construcciones de sujetos están contenidos los observadores, las epistemologías de éstos y los sistemas de tipificaciones, éstas a su vez están contenidas en una estructura por tanto son discursos lenguajes elaborados por personas/ equipos/ instituciones, desde una posición de poder, desde una posición en relación al sujeto que es descrito.

11. Respecto a la estructuración de políticas sociales, en los ochenta, la alteridad, el otro, el sujeto no estaba contenido en ellas. Las políticas sociales eran más bien las "políticas del bulto", esta invisibilización, negación del otro, contiene en su distinción una negación del 
entorno, el poder y el conocimiento están autoimplicados, contenidos en la relación de poder Estado-Nación. En este sentido el discurso se hace efectivo como mecanismo regulador y organizador de las relaciones de poder.

En la década de los noventa el lenguaje, los discursos y tipificaciones incorporan la alteridad, a los sujetos sociales, resituándolos en una nueva relación de legitimación de sus derechos y de relaciones entre los sujetos y el Estado. Se visibiliza la heterogeneidad, sin embargo puedo afirmar que aún nos encontramos con dificultades para valorar la diversidad. Desde otro punto de vista, es posible afirmar que los sujetos emergentes son incorporados en las distinciones del Estado, se autoimplican por tanto en/ desde allí se resitúan las relaciones de poder. Los procesos de exclusión/ inclusión permiten conjugar la necesidades de los sujetos y las necesidades de control del Estado.

12. Los espacios que se abren desde la institucionalidad, se abren a nuevos sujetos y problemáticas. Cabe destacar que una diferencia importante es que la institucionalidad de FONADIS y SERNAM se diferencian en cuanto la primera se caracteriza por una apertura a la problemática, pero es la segunda quien en concreto no sólo se abre a la problemática sino también a los propios sujetos, es decir la estructura incorpora a las mujeres como parte de ésta. Es decir, es recursiva en cuanto contiene al sujeto que orienta su accionar. En este sentido, el proceso está marcado también por la propia evolución de los sujetos, es decir, los sujetos son institucionalidad y sociedad civil a su vez, lo que es evidente en los últimos años de la década de los noventa.

13. El rol asignado a los medios de comunicación desde la institucionalidad requiere ser destacado. Los medios de comunicación son considerados constructores y promotores de imágenes de sujetos, desde el reconocimiento de las diversas realidades de éstos así como también de los aportes y participación de los sujetos en los ámbitos sociales culturales, económicos. Se les sugiere, desde la institucionalidad, un respeto y reconocimiento de la diversidad e identidades, así como un reconocimiento a los valores, experiencias y culturas. Sin embargo cabe dejar abierta la discusión en torno a que imágenes y desde donde los medios de comunicación podrían desarrollar esta tarea; si reconocemos que por un lado ellos construyen y reproducen estereotipos e imágenes de sujeto, desde sus propias distinciones, son parte de los procesos de inclusión/ exclusión social, y a la vez reconocemos que los medios de comunicación albergan a sujetos que en su vida laboral y cotidiana son parte del mismo sistema de representaciones, es decir, ellos estarían contenidos en las imágenes de sujetos que producen/ reproducen/ invisibilizan.

14. Es importante destacar que si bien respecto a las mujeres hoy se elaboran construcciones que dan cuenta de las diferencias, las epistemologías que se utilizan para el reconocimiento de éstos sujetos contienen limitaciones; en otras palabras, se centran en parámetros establecidos los que se refieren a diferencias sociales y económicas, desde indicadores de carencia o de pobreza, principalmente.

Es importante señalar que desde este modo de conocer a las mujeres se dejan fuera aspectos que permitirían elaborar distinciones referentes a la totalidad de las mujeres. Si bien discursivamente se reconoce a fines de los noventa una heterogeneidad de las mujeres situadas en base a parámetros diferenciadores, por ejemplo de estrato social, educación, laboral, quedan fuera la evaluación de las potencialidades, de los aspectos sobre los que las mujeres construyen identidad. Un ejemplo claro de esta afirmación es que si bien hoy el discurso reconoce la diversidad y heterogeneidad de las mujeres, este no se refiere, ni tampoco contempla en lo específico a mujeres indígenas. Este parece ser un tema 
contenido en otra estructura dentro del MIDEPLAN. Desde esta mirada y extrapolando otros campos conclusivos: ¿quién se hace cargo de la situación de las mujeres indígenas?. Sin ir más lejos, ¿qué sucede, quien "ve" a las mujeres con orientaciones sexuales diferentes?. Cabe señalar que el Plan de Igualdad de Oportunidades entre mujeres y hombres 20002010, se refiere al tema étnico, diferenciación de clase, pero no cuestiona la necesidad de establecer nuevas distinciones respecto de las diferencias de género en el contexto de las culturas indígenas que habitan en nuestro país, pareciera asumirse que los procesos de inclusión/ exclusión son similares.

En síntesis las construcciones de otredad, de sujetos que ha elaborado la institucionalidad, nos permiten dar cuenta de las dimensiones relacionales que elaboramos en nuestro país.

15. Es importante señalar que las distinciones, las comunicaciones que se establecen respecto a los sujetos, a las mujeres, su situación, da cuenta de los procesos de inclusión/ exclusión primaria y secundaria así como de procesos de integración social y de construcción de identidad.

A lo largo del análisis de los datos recogidos es posible desprender y asociar las distinciones de sujetos que realizan los y las hacedoras de políticas sociales como elementos que se reproducen en las comunicaciones de sentido. Desde los propios sujetos también se produce un diálogo que desencadenará procesos de individuación de los sujetos mujeres y personas con discapacidad.

16. En la lógica anterior, las sociedades de riesgo, los sujetos están presionados a tomar decisiones, en donde los individuos parecen al centro de la sociedad pero no al centro de las instituciones. Desde allí se produce el quiebre, la estructura se hace recursiva en la política de la representatividad, esto es desde la afirmación de que las instituciones, el Estado ve sólo lo que es capaz de distinguir, se producen vacíos en las políticas sociales.

Se produce un traslado de las relaciones y comunicaciones que se "desean transformar", como es el tema del poder y las relaciones de desigualdad y discriminación que viven los sujetos y las mujeres con discapacidad. En donde aparece imposible conjugar los derechos individuales y las estructuras de representatividad.

17. La lógica que se desprende en el desarrollo de las políticas sociales, lógica que se mantiene a pesar de los cambios políticos y en los modos de distinguir a los sujetos sociales, es la lógica de políticas sociales dirigidas a superar la marginalidad y la pobreza a través de la incorporación de éstos al mercado.

Sin embargo, resulta importante establecer distinciones diferenciadas que permitan por un lado reconocer los procesos de individuación e individualización de los sujetos. De esta manera es posible identificar procesos dinámicos de inclusión/ exclusión de los sujetos sociales lo que permitirá profundizar en las acciones necesarias desde las políticas sociales y desde la construcción de estructuras. En este sentido no es menor la construcción de representaciones de los sujetos en cuanto estos determinan desde las estructuras los marcos de construcción de individualidad de los sujetos sociales.

18. Quisiera detenerme en un aspecto que aparece recursivamente en el tema de las mujeres. A través de la elaboración y trabajo desarrollado a partir de la aplicación del Plan de Igualdad de Oportunidades 1994-1999, se instala comunicacionalmente y en el lenguaje discursivo la temática de la igualdad. Me parece relevante en cuanto desde la mirada del 
binomio inclusión/ exclusión debiéramos detenernos un poco. Este Plan señala que su propósito es "promover la redistribución entre (56) los géneros de los recursos y tareas sociales, derechos civiles y participación, posiciones de poder y autoridad y valoración de las actividades que realizan hombres y mujeres". A partir de esta afirmación se parte de la base de que las desigualdades y la discriminación entre hombres y mujeres es vivida de igual manera, quedan fuera por tanto las diferencias que existen por identidad sexual, clase, discapacidad, etnia. A lo anterior se agrega que no se menciona ni en el Plan 1994-1999, ni 2000-2010 las diferencias que existen intragénero, es decir las situaciones de discriminación, relaciones de poder, exclusión, existente entre las mujeres de acuerdo a las características antes mencionadas. En otras palabras es posible señalar que a pesar de que los documentos han sido elaborados bajo mecanismos participativos, estos siguen recogiendo y recreando distinciones elaboradas por mujeres de clase media, blancas.

19. Respecto al concepto de igualdad, este parece estrechamente asociado a la idea o el ideario de democracia. Sin embargo este resulta más bien restringido a lo legal, en cuanto ciudadanos capacitados para los mismos derechos. Pero cabe la pregunta, ¿es posible acceder a los mismos derechos cuando existen diferencias culturales, físicas que requieren la determinación de distinciones precisas? Es posible hablar de igualdad desde un sistema que no distingue como entorno a los pueblos indígenas o a las personas con discapacidad, etc?

Finalmente quisiera detenerme en una invitación reflexionada, o más bien en una reflexión que invite. Como cientistas sociales requerimos de nuevos paradigmas que nos posibilite observar nuestras propias observaciones, así mismo realizar observaciones sobre las observaciones de otros. Esta "mirada" nos permitirá establecer nuevos marcos descriptivos y explicativos, de modo de generar evaluaciones, explicaciones, reformulaciones diversas o simplemente una toma de conciencia respecto de lo que somos capaces de generar desde la institucionalidad.

Las políticas sociales actualmente, navegantes de la globalización, sumergidos en las profundidades de la diversidad, requieren ser distinguidas de manera de dar cuenta de los procesos en que se construyen los mapas de navegación. Las orientaciones que nos han permitido establecer, el horizonte, las estrellas, los grandes astros no son más que líneas, o límites que marcan un entorno, un dentro/ fuera, que es más bien generado por quien observa, sabemos ya que nuestras propias distinciones, lo que somos, hacemos, es parte de lo que dejamos fuera o dentro; en otras palabras quien dice que las estrellas, los astros el océano, la tierra que está bajo nuestro zapatos, el aire que respiramos ya no son parte de nosotros mismos.

\section{Notas}

1) Esta tesis ha recibido el aporte de: Becas de financiamiento parcial de tesis de postgrado año 2000, del Departamento de Postgrado y Postítulo de la Vicerrectoría de Asuntos Académicos de la Universidad de Chile y el Programa de Intercambio FLACSO - CHILE, Universidad de Duke y Universidad de Carolina del Norte, año 2001.

2) De acuerdo al Diccionario llustrado de la lengua española Aristos (1997), Quídam es definido como: "Sujeto indeterminado. Sujeto sin importancia de poco valor cuyo nombre se ignora o no se quiere enunciar". 
3) MIDEPLAN: Ministerio de Planificación Nacional. SERNAM, Servicio Nacional de la Mujer. FONADIS, Fondo Nacional para la discapacidad. CONADI, Corporación Nacional de Desarrollo Indígena. FosIS Fondo de Solidaridad e inversión Social E INJUV Instituto Nacional de la Juventud.

4) Araujo, Kathya; Guzmán, Virginia; Mauro, Amalia El surguimiento de la violencia doméstica como problema público y objeto de políticas. Revista de la Cepal 70, abril 2000-06-11 Pág. 133145.

5) Bengoa, José. Políticas publicas y comunidades mapuches: del indigenismo a la autogestión.. Revista perspectivas en Política, economía y gestión. Volumen 3. Número 2-2000. Pág. 331-365. Depto de Ingeniería Industrial. Fac. de Cs. Físicas y Matemáticas. Universidad de Chile.

6) Godoy, Roberto. 1999.Participación ciudadana en el espacio local: hacia una nueva ciudadanía en Chile. Memoria para optar al grado de Magister en Gestión y Políticas Públicas,. Universidad de Chile. Facultad de Ciencias Físicas y matemáticas. departamento de ingeniería industrial.

7) Secretaría de Comunicaciones y Cultura. Chile. 1999. El enfoque social: para las grandes minorías. Zona Pública 34. Noviembre/ Diciembre. Paginas 4-11. Ver anexos.

8) Para efectos del proyecto siguiente entenderemos estructura institucional como las instituciones dependientes del Mideplan, que serán consideradas para efectos del presente estudio: FONADIS, SERNAM.

9) Discusiones, reflexiones de clases: Antropología de la Marginación Social. Fernando Robles. 2000. Universidad de Chile.

10) Estrategias de participación, definidas desde el diagnóstico, elaboración de propuestas de acción, ejecución y elaboración de marcos de acción, propuesto y ejecutados en especial a través de los programas de acción definidas desde el FOSIS. EI FOSIS en su esfuerzo dirigido a la superación de la pobreza, aporta enfoques metodológicos innovadores y complementarios a los otros organismos del estado y el marco de sus acciones a través del desarrollo de programas, dirigidos a microempresarios, adultos mayores, jóvenes, organizaciones urbanas rurales, de localidades pobres, productores rurales, pescadores artesanales, mujeres y niños/ as.

11) De Laire, Fernando; Saldaña, Lucía. Parte III, Por un enfoque integral y sistémico de política social: entre los sociopolítico y lo técnico. Las bases filosóficas e históricas de la equidad y los enfoques de política públicas sobre ésta. Proyecto conjunto Universidad Alberto Hurtado MIDEPLAN. 1999

12) Barros, P; De los Rios, d; Torche, F. Lecturas sobre la exclusión social. Oficina internacional del trabajo. Equipo técnico multidisciplinario para Argentina, Chile, Brazil, Paraguay y Uruguay. 1996

13) Barros, P; De los Ríos, d; Torche, F. Op. cit 
14) Apuntes clases. Antropología de la Marginación. Fernando Robles. Magíster Antropología y Desarrollo. Universidad de Chile. 2000.

15) Apuntes clases. Antropología de la Marginación. Fernando Robles. Magíster Antropología y Desarrollo. Universidad de Chile. 2000.

16) Luhmann, N. Capitulo 8. Inclusión y exclusión. En Complejidad y Modernidad. Ed. Trotta. 1998.

17) Luhmann, N. Capitulo 8. Inclusión y exclusión. En Complejidad y Modernidad. Ed. Trotta. 1998.

18) Luhmann, N. Op.Cit

19) Robles, Fernando. Op.Cit

20) Fernando Robles, Op. cit.

21) Fernando Robles, Op. cit.

22) Herzfeld, Michel. 1993. The social production of indifference. Exploring the symbolic roots of Western Bureocracy. University of Chicago Press Edition. United States.

23) Burchell, G.; Gordon, C, Miller, P. 1991. The Foucault Effect. Studies in Govermentality. With two lectures by and interview with Michael Foucault. University of Chicago Press. United States.

24) El autor señala, como ejemplo de lo anterior, la idea de la relación de consanguinidad. Este ha sido uno de los diferenciadores sociales, que opera en las relaciones sociales y también se institucionaliza cuando vemos que las leyes definen las relaciones de parentesco a partir de la relación de consanguinidad. Las relaciones de consanguinidad, el símbolo de la "sangre" como articulador de relaciones sociales y culturales no sólo se incorporaría a los procesos de inclusión sino también como articulador de procesos de exclusión.

25) Traducción libre del texto de Herzfeld, Michel, realizada por la autora.

26) Burchell, Graham; Gordon, Colin; Miller, Peter Editors. 1991. The Foucault Effect: Studies in governmentality. With two lectures by and an interview with Michael Foucault.

27) Traducción libre de la autora.

28) Adaptación libre del texto original en versión en inglés.

29) De Laire Op. Cit

30) "Breve Historia Administrativa del Ministerio de Planificación y Cooperación". Boletín informativo editado por la Biblioteca del Ministerio de Planificación y Cooperación: p.1

31) Texto actualizado de las normas que rigen al Ministerio de Planificación y Cooperación y a los Servicios Públicos relacionados con MIDEPLAN. Enero 1992. P.1 
32) "Breve Historia Administrativa del Ministerio de Planificación y Cooperación”: Op. cit, p:3

33) Texto actualizado de las normas que rigen al Ministerio de Planificación. Op. cit, p: 23

34) "Breve Historia Administrativa del Ministerio de Planificación y Cooperación": op.cit.p:3

35) http://sernam.cl/estudios main.html 08/07/2000

36) SERNAM. Plan de Igualdad de Oportunidades para las Mujeres. 1994 - 1999. 1996. Santiago.

37) SERNAM. Políticas Públicas para la Mujer. Seminario Internacional. 1996. Santiago

38) Plan de Igualdad de Oportunidades para las Mujeres 1994-1999. SERNAM.

39) Plan de Igualdad de Oportunidades entre Mujeres y Hombres. Lineamientos generales. 2000-2010. SERNAM

40) MIDEPLAN. 1999. Documento № 11. Situación de la mujer en Chile 1998. Resultado Encuesta de Caracterización Socioeconómica Nacional, CASEN 1998.

41) De Laire, Fernando. Saldaña, Lucía. Las bases filosóficas e históricas de la equidad y los enfoques de políticas públicas sobre esta. Parte III. Por un enfoque integral sistémico de política social: entre lo sociopolítico y lo técnico. Proyecto conjunto Universidad Alberto Hurtado MIDEPLAN.

42) Información Pagina Web. http://www.fonadis.cl/queesfonadis.htm 08-07-2000

43) No sólo el tema de la discapacidad no había sido incorporado en los sistemas de registro poblacional. Es a través de los múltiples mecanismos desencadenados que se incorporan temáticas que aparecen invisibilizadas en la problemática social. Al igual que el tema de género, edad, etnias, discapacidad surgen en el proceso de construcción democrática. Estos "sujetos se hacen visibles" a partir de las demandas y movimientos que hacen evidente la presencia y problemática asociadas. Se incorporan en el Censo 1992, lo étnico, y en 1996 en la encuesta Casen el tema de la discapacidad, constituyéndose en instrumentos en procesos de definición, pues han mostrado las dificultades en los mecanismos de registro e identificación.

44) Op. Cit

45) Cabe destacar que determinadas políticas sociales, especialmente las políticas de salud orientaron políticas de salud a las mujeres pero en el entendido binomio madre- hijo, desde donde las mujeres son identificadas en su función en el proceso de reproducción y en la medida que la intervención y cuidado sobre ella permite un mayor control de los indicadores de morbilidad-mortalidad de las mujeres y los hijos de éstas.

46) El sistema educativo es reconocido como un espacio en donde se producen conocimientos, cultura y se genera información que intervienen en las desigualdades sociales. En el diagnóstico de la temática se señala que la discriminación no sólo se produce por el desigual acceso al sistema, sino por la calidad y la modalidad de enseñanza, es decir no sólo los 
contenidos que se imparten sino los mecanismos que se utilizan para transmitirlos reproducirían estas desigualdades entre hombres y mujeres. Estas formas implícitas y explícitas estarían determinando las representaciones de si mismos de los sujetos y de la relación entre hombres y mujeres, a lo que me permitiré agregar las diferencias y reproducción de poder, entre alumnos/ as y entre estos y el profesorado, por señalar alguno.

47) SERNAM. 1996. Plan de Igualdad de Oportunidades para las Mujeres. 1994-1999.

48) SERNAM. 1996. Plan de Igualdad de Oportunidades de las Mujeres 1994-1999.

49) Esta apertura señala que en uno de cuatro hogares la mujeres es agredida físicamente y que en uno de cada tres hogares las mujeres son maltratadas psicológicamente en la Región Metropolitana SERNAM. 1996. Plan de Igualdad de Oportunidades para las Mujeres 1994-1999.

50) La discriminación se traduce no sólo en la imposibilidad de acceso de las mujeres, sino también en la imposibilidad que como estructura y sociedad tenemos de traducir y valorar a los sujetos. El tema de la discriminación de los sujetos sociales es un tema nuevo para la estructura y para la sociedad, es decir un replanteamiento de las significaciones simbólicas y materiales con que se definen a los sujetos.

51) Me parece importante reflexionar en torno a la instalación y refuerzo público de la relación de asimetría, la que se evidencia ante la representación discapacidad - caridad, la discapacidad estará asociada a la pobreza, a la imposibilidad de las personas de insertarse laboral, social, económicamente. Luego las personas son instaladas desde una condición de símbolo y objeto de caridad a partir de las acciones implementadas por la Teletón quien pone en lo público el tema de la discapacidad en la década de los ochenta. La idea de símbolo asociada al consumo, es decir se consume y a través del consumo se contribuye a que el niño/ a símbolo logre la meta; ser sujeto, en su esfuerzo por ser como los otros, dejar la condición de discapacidad, de anormalidad. La caridad es cambiada por el consumo asociado a imágenes símbolos; de esfuerzo, superación, de cambio de la anormalidad a la normalidad.

52) La idea de limitación, como un cerco, demarcación del territorio, este territorio sería establecido desde la carencia, desde la diferencia en la capacidad, entendiendo esta como la aptitud o la suficiencia para una cosa, en este sentido se "habla de capacidades diferentes".

53) Es por ello que a pesar de que los antecedentes dan cuenta que las discapacidades más recurrentes en la población son: en un 27,3\% discapacidades para oír, principalmente en población adulta. Discapacidad para ver de un 26,9\% y discapacidades físicas de un 21,2 \%. Los porcentajes disminuyen son relación a la discapacidad mental 13,1\%, discapacidad por causa psiquiátrica 5,9\% y discapacidad para hablar 5, 6\%. Es la discapacidad física la que pareciera concentrar las preocupaciones y distinciones desde el entorno.

54) Revista publicada por FONADIS, de distribución gratuita. Revisada y analizada ver anexo.

55) Desde las representaciones de sujetos centradas en las carencias, en las limitaciones, en la invisibilidad en que se sumerge, la traducción desde la estructura es la elaboración de mecanismos con el fin de crear espacios para personas "especiales", se les entrega educación "especial" acorde a sus características "especiales". Es decir se distingue la diferencia, desde ésta no sólo el sujeto, sino la familia es estigmatizada, reconocida desde ella. A partir de ello la acción estará orientada a ocultar, relegar, o anular las capacidades de las personas, 
haciéndolas dependientes, no sólo de las familias sino también de la institucionalidad, en la medida que se le distingue desde la no capacidad, el sujeto no es "capaz" de estar, de hacer, de ser.

56) Cursivas son mías. 
Revista Mad. No.7. Septiembre 2002. Departamento de Antropología. Universidad de Chile http://rehue.csociales.uchile.cl/publicaciones/mad/07/paper09.pdf

\section{Bibliografía}

ALVAREZ, S.; DAGNINO, E.; ESCOBAR, A. (1998) Cultures of politics Politics of cultures: re- visioninning Latin American Social Movements. Westview Press

ARAUJO, Kathya ; GUZMÁN, Virginia; MAURO, Amalia. (2000) "El surgimiento de la violencia doméstica como problema público y objeto de políticas". en Revista de la CEPAL. 6(11): 133-145. Abril.

BARROS, P.; DE LOS RIOS, D.; TORCHE, F. (1996) Lecturas sobre la exclusión social. Oficina internacional del trabajo. Equipo técnico multidisciplinario para Argentina, Chile, Brazil, Paraguay y Uruguay.

BAYOUMI, Moustafa; RUBIN, Andrew, (ed.) (2000) The Edward Said Reader. New York, Vintage Books.

BENGOA, José. (2000) "Políticas publicas y comunidades mapuches: del indigenismo a la Autogestión" en Revista Perspectivas en política , economía y gestión. Universidad de Chile, Depto de Ing. Industrial. Fac. de Cs. Físicas y Matemáticas. 3(2): 331-365

BERGER, T.; LUCKMAN, T. (1994) La construcción social de la realidad. Buenos Aires, P. Amorrortu Editores.

BLUMER, Helbert. The idea of social development. Barkeley. U. California

BRUNNER, J., et al. (1993) Paradigmas de conocimiento y práctica social en Chile. Santiago, Chile, FLACSO.

BURCHELL, G.; GORDON, C.; MILLER, P. (1991) The Foucault effect: studies in Govermentality with two lectures by and interview with Michael Foucault. Chicago, University of Chicago Press.

CHAVEZ, R. (1999) Políticas Publicas, igualdad de oportunidades y la participación social y política de las mujeres SERNAM (Chile 1990-1998). (Memoria para optar al grado de Magíster en Gestión y Políticas Públicas). Santiago, Chile, Universidad de Chile.

CORKER, M.; FRENCH, S., (eds.) (1999) Disability Discourse. Philadelphia. Open University Press Buckingham.

CORVALAN, J. (1996) Paradigmas de lo social y las concepciones de intervención en la sociedad. Santiago, Chile, CIDE. (Documentos №4)

CHILE. República de Chile. Servicio Nacional de la Mujer. [en línea), [ URL: http://sernam.cl/estudios main.html) , consulta: 08/07/2000

CHILE. República de Chile. Oficina de Planificación Nacional. Su acción abril de 1974. Santiago, Chile, ODEPLA. 
Revista Mad. No.7. Septiembre 2002. Departamento de Antropología. Universidad de Chile http://rehue.csociales.uchile.cl/publicaciones/mad/07/paper09.pdf

CHILE. Servicio Nacional de la Mujer. Plan de Igualdad de Oportunidades entre Mujeres y Hombres: lineamientos generales. 2000-2010. Santiago, Chile, SERNAM.

CHILE. Ministerio de Planificación. 1992. Texto actualizado de las normas que rigen al Ministerio de Planificación y Cooperación e a los Servicios Públicos relacionados con Mideplan

CHILE. Ministerio de Planificación. 1998. Situación de la mujer en Chile 1998. Resultado Encuesta de Caracterización Socioeconómica Nacional, CASEN 1998. Santiago, Chile, Mideplan, 1998.

CHILE. Ministerio de Planificación y Cooperación. Breve Historia Administrativa del Ministerio de Planificación y Cooperación". Boletín informativo

CRENSHAW, K. (1997) Intersectionaly and identity politics: learning from violence against women of color. From reconstracting political theory: Feminist Perspectives. Penn State Press.

DAVIS, L., eds. (1997) The disability studies reader. New York, Routledge

DE LAIRE, Fernando; SALDAÑA, Lucía (1999) Parte III. Por un enfoque integral sistémico de política social: entre lo sociopolítico y lo técnico En: Las bases filosóficas e históricas de la equidad y los enfoques de políticas públicas sobre ésta. Proyecto conjunto Universidad Alberto Hurtado - Mideplan.

ESCOBAR, A.; ALVAREZ, S., eds. (1992) The making of social movements in Latin America. identity, strategy and democracy. Oxford, Westview Press Boulder.

ESCOBAR, A. Antropología y Desarrollo. spi.

El enfoque social: para las grandes minorías. 1999. Zona Pública (34): 4-11. Noviembre/Diciembre.

FOCAULT, Michel. 1999. La arqueología del saber. 19ª ed. Siglo Veintiuno Editores.

FOCAULT, Michel. 1999. Las palabras y las cosas. Una arqueología de las ciencias humanas. 29a ed. español. Siglo Veintiuno Editores.

FONADIS (2001) Atrévete a ponerte en mi lugar. Santiago de Chile.

FONADIS. Bases concurso Nacional de Proyectos 1997- 1999

FONDO NACIONAL DE LA DISCAPACIDAD . [en línea), [URL:

http://www.fonadis.cl/queesfonadis.htm), consulta:

GODOY, Roberto. (1999) Participación ciudadana en el espacio local: hacia una nueva ciudadanía en Chile (Memoria para optar al grado de Magister en Gestión y Políticas Públicas). Santiago, Chile, Universidad de Chile. . Facultad de Ciencias Físicas y matemáticas. Departamento de Ingeniería Industrial. .

HALL, S. Espectacle of the other. spi. 
Revista Mad. No.7. Septiembre 2002. Departamento de Antropología. Universidad de Chile http://rehue.csociales.uchile.cl/publicaciones/mad/07/paper09.pdf

HALL, S.; GIEBAN, B. Formations of modernity. Polity Press and Open University

HERZFELD, Michel. (1993) The social production of indifference. Exploring the symbolic roots of western bureocracy. Chicago, University of Chicago Press

JODELET, Denise. La representación social: fenómenos conceptos teoría. En: Psicología Social II.

LINTON, S. (1998) Claiming disability: knowledge and identity. New York, University Press.

LUHMANN, N (1998) Inclusión y exclusión En: Complejidad y modernidad. Ed. Trotta, Madrid.

MONTECINO, S.; ROSSETTI, J, ed (1990) Tramas para un nuevo destino. Propuesta de la concertación de mujeres por la democracia.

MONTECINO, S.; OBACH, A (1999) Comp. Género y epistemología. Mujeres y Disciplina. Santiago, Chile, Lom Ediciones.

OSORIO, Francisco. (1999) "El científico social entre la actitud natural y la actitud Fenomenológica" [en línea) Cinta de Moebio (5), Universidad de Chile. [URL:http://rehue.csociales.uchile.cl/publicaciones/moebio/05/frames02.htm)

Políticas Públicas para la Mujer. Seminario Internacional. (1996) Santiago SERNAM.

RACZYNSKI, D.; SERRANO, C. Abriendo debate: descentralización del estado, mujeres y políticas sociales.

RICHARDS, P. Expandir el concepto de la ciudadanía de las mujeres: la visión de pueblo y la representación de las mujeres mapuches en Sernam. spi. Documento inédito.

ROBLES, Fernando. (1999) Los sujetos y la cotidianidad. Elementos para la microsociología de lo contemporáneo. Ediciones sociedad hoy. (Serie estudios sociológicos).

SAD, Edward. (1994) Orientalism. New York, Vintage Books.

SCHUTZ, Alfred. (1962) El problema de la realidad social. Buenos Aires, Amorrortu Editores.

SEMINARIO INTERNACIONAL. Políticas públicas para la mujer (1996, Santiago, Chile) Plan de Igualdad de Oportunidades para las Mujeres. 1994 - 1999. Santiago, Chile SERNAM, 1997.

Seminar Dialogue on development and inclusion: opportunities for people with disabilities. (2001, Santiago, Chile, Inter American Development Bank)

SCHUTZ, A.; LUCKMANN, T. Las estructuras de la vida. Buenos Aires, Amorrortu Editores. 
STEFONI, Carolina. (1999) Cultural representation of Latin American in American Films. (Thesis MA (Taught) Cultural Studies) . University of Berminghan

STUART, H.; DU GAY, P. (1996) Questions of cultural identity. London, Sage Publications.

TENTI, Emilio. (1996) Actores, acción colectiva y participación en el campo de las políticas públicas. EN: Seminario Internacional Gobernabilidad: perspectiva democrática. Universidad de Chile. Centro de Estudios y Políticas Publicas.

THOMAS, C. (1999) Female forms: experiencing and understanding disability. Philadelphia, Open University Press.

URZUA, Raúl, (ed.) (1997) Cambio social y políticas públicas. Santiago, Chile, Universidad de Chile. Centro de Estudios y Política Publicas.

WOOLASRD, K.; SCHIEFFELIN, B. (1994) "Language Ideology" en Revista Antropología (23):55-82 . [URL: http:/www.jstor.org/) 